\title{
Water-Quality Data-Collection
}

Activities in Colorado and Ohio: Phase I-Inventory and

Evaluation of 1984 Programs and Costs

United States Geological Survey Water-Supply Paper 2295-A

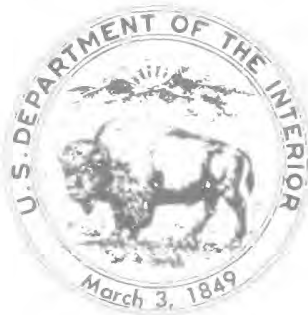


Chapter A

Water-Quality Data-Collection

Activities in Colorado and Ohio:

Phase I-Inventory and

Evaluation of 1984

Programs and Costs

BY JANET HREN, THOMAS H. CHANEY, J. MICHAEL NORRIS, and CAROLYN J. OBLINGER CHILDRESS

U.S. GEOLOGICAL SURVEY WATER-SUPPLY PAPER 2295

WATER-QUALITY DATA-COLLECTION ACTIVITIES IN

COLORADO AND OHIO 


\title{
DEPARTMENT OF THE INTERIOR DONALD PAUL HODEL, Secretary
}

\author{
U.S. GEOLOGICAL SURVEY \\ Dallas L. Peck, Director
}

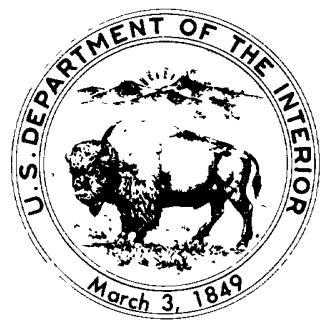

For sale by the

Books and Open-File Reports Section

U.S. Geological Survey

Federal Center

Box 25425

Denver, CO 80225

Library of Congress Cataloging-in-Publication Data

Main entry under title:

Water-quality data collection activities in Colorado and Ohio.

(Water-supply paper / U.S. Geological Survey ; 2295)

Bibliography: $p$.

Supt. of Docs. no.: I 19.13:2295

1. Water quality-Colorado-Measurement. 2. Water quality-OhioMeasurement. I. Hren, Janet.

II. Series: Geological Survey water-supply paper ; 2295.

TD224.C7W37 $1985 \quad 363.7^{\prime} 3942^{\prime} 09788 \quad 85-600347$ 


\section{FOREWORD}

One of the greatest challenges faced by the Nation's water-resources scientists is the need for reliable information that will guide the protection of our water resources. That challenge is being addressed by Federal, State, interstate, and local water-resource agencies and by many academic institutions. Many of these agencies are collecting water-quality data for a host of purposes including: compliance with permits and watersupply standards; development of remediation plans for a specific contamination problem; operational decisions on industrial, wastewater, or water-supply facilities; and research on water quality. Prominent is the need for information on a regional and national basis, and on the trends and causes of water-quality conditions. Without this information, policy decisions may be made based on information from a few localized problems. Conversely, a lack of information may lead to a false sense that some problems do not exist. In the past two decades, billions of dollars have been spent on water-quality data-collection programs. However, only a small part of the data collected by these programs have been obtained specifically to assess the status, trends, and causes of water-quality conditions on regional and national scales. Also, in some instances, the utility of these data for present and future regional and national assessments is limited by such factors as the areal extent of the sampling network, frequency of sample collection, and the types of water-quality characteristics determined.

The water-quality data collected for permits, or compliance and enforcement purposes constitute a sizable source of information that may be suitable for regional and national assessments. Such data must, however, be carefully screened before use. The needs, uses, and types of water-quality data vary widely, and data collected for one purpose are not necessarily suitable for other purposes. In fact, the use of unsuitable data in regional or national assessments can be much worse than a lack of information, because the use of such data can lead to incorrect conclusions having far-reaching consequences.

Accordingly, the U.S. Geological Survey, with cooperation from other agencies and from universities, has undertaken a pilot study in Colorado and Ohio to determine the characteristics of existing Federal and non-Federal water-quality datacollection programs and to evaluate the suitability of the data bases from these programs for use in water-quality assessments of regional and national scope. This report describes the results of phase one of the study. This study does not imply that past and present data-collection programs have failed or are inappropriate for their intended purposes. The data from those programs may fully meet individual agency needs and fulfill their mandated requirements, yet may have only limited relevance to water-quality questions of regional and national scope.

This study has depended heavily on cooperation and information from many Federal, State, regional, and local agencies and academic institutions. The assistance and suggestions of all are gratefully acknowledged, and their respective water-quality programs in Colorado and Ohio are cited in this report.

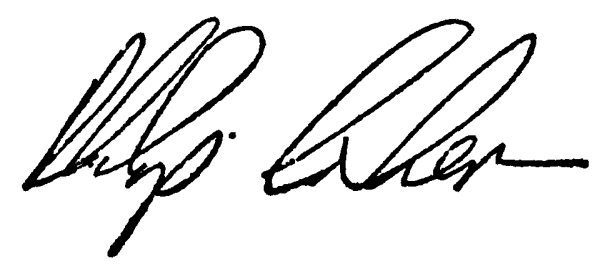

Philip Cohen

Chief Hydrologist 


\section{CONTENTS}

Glossary VIII

Executive summary 1

Introduction 4

Background 5

Project objectives and approach 5

Phase-I purpose and scope 7

Methods of acquiring, compiling, and evaluating information 7

Description of questionnaire 7

Identification of organizations collecting water-quality data 8

Determination of water-quality data costs 9

Screening criteria 9

Organizations collecting water-quality data 10

Colorado 10

Ohio 12

Comparison between States 12

Purposes of water-quality data collection $\mathbf{1 3}$

Colorado 14

Ohio 14

Comparison between States 14

Types of water-quality determinations 15

Colorado 15

Ohio 15

Comparison between States 15

Costs of water-quality data 18

Colorado 18

Ohio 19

Comparison between States

22

Evaluation of water-quality data $\mathbf{2 2}$

Colorado 23

Surface water 23

Ground water $\mathbf{2 6}$

Ohio 28

Surface water $\mathbf{2 8}$

Ground water $\mathbf{2 8}$

Comparison between States 29

References 30

Supplemental data $\mathbf{3 3}$

Questionnaire 34

Instructions for questionnaire $\mathbf{4 3}$

Tables 7 through $21 \quad 50$

\section{FIGURES}

1. Photographs showing different land uses that can affect water quality 6

2. Diagrams showing distribution of water-quality samples reported for 1984 by organizational category 12

3. Diagrams showing samples reported for $\mathbf{1 9 8 4}$ for the purposes of meeting permit requirements, undertaking compliance-and-enforcement activities, or characterizing ambient conditions 14 
FIGURES

4-7. Graphs showing:

4. Comparison of the numbers of water-quality samples reported for the purposes of meeting permit requirements, undertaking compliance-and-enforcement activities, or characterizing ambient conditions in Colorado and Ohio, 198415

5. Numbers of surface-water samples reported for 1984 , by major property and constituent groups 16

6. Numbers of ground-water samples reported for 1984, by major property and constituent groups 17

7. Numbers of surface- and ground-water samples by major property and constituent groups, Colorado and Ohio, 198418

8. Diagrams showing percentages of estimated laboratory costs for the purposes of meeting permit requirements, undertaking compliance-andenforcement activities, or characterizing ambient conditions during 198419

9. Graph showing estimated costs for laboratory analysis of surface- and ground-water samples, by property and constituent group, 198421

10-13. Diagrams summarizing:

10. Screening results for surface-water samples and their estimated laboratory costs, Colorado and Ohio, 198424

11. Screening results for surface-water samples for Federal, State, regional, and local agencies and academic institutions, 198425

12. Screening results for ground-water samples and their estimated laboratory costs, Colorado and Ohio, 198426

13. Screening results for ground-water samples for Federal, State, regional, and local agencies and academic institutions, 1984

TABLES

1. Organizations reporting water-quality data-collection programs and numbers of programs reported, Colorado, 198411

2. Organizations reporting water-quality data-collection programs and numbers of programs reported, Ohio, 198413

3. Summary of estimated laboratory costs by organizational category, Colorado, 198420

4. Summary of estimated laboratory costs by organizational category, Ohio, 198423

5. Numbers and percentages of samples and estimated laboratory costs (surface water and ground water combined) before and after screening, by source of data, Colorado and Ohio, 198429

6. Numbers and percentages of samples and estimated laboratory costs (surface water and ground water combined) before and after screening, by property and constituent groups, Colorado and Ohio, 198430

7. Organizations with water-quality data-collection programs active in Colorado during 1984 and the property and constituent groups for which data were reported $\mathbf{5 0}$

8. Organizations with water-quality data-collection programs active in Ohio during 1984 and the property and constituent groups for which data were reported $\mathbf{5 5}$

9. U.S. Geological Survey laboratory codes, detection limits, and costs for measurements and analyses used to estimate laboratory costs $\mathbf{5 8}$ 
TABLES

10. Numbers and estimated costs of: all surface-water measurements and analyses; those meeting either the ambient-conditions or the dataavailability criteria; and those meeting both screening criteria, by source of data, Colorado, 198460

11. Numbers and estimated costs of: all ground-water measurements and analyses; those meeting either the ambient-conditions or the dataavailability criteria; and those meeting both screening criteria, by source of data, Colorado, 198461

12. Numbers and estimated costs of: surface-water-sample analyses meeting both the ambient-conditions and the data-availability criteria and either the location, quality-assurance, or the computerization criteria; and those meeting all five criteria, by source of data, Colorado, 198462

13. Numbers and estimated costs of: ground-water-sample analyses meeting both the ambient-conditions and the data-availability criteria and either the location, quality-assurance, or the computerization criteria; and those meeting all five criteria, by source of data, Colorado, 198463

14. Estimated laboratory costs of surface-water samples meeting all screening criteria collected for determining ambient conditions and compliance-andenforcement purposes, listed by physical properties and major constituent groups, Colorado, 198464

15. Estimated laboratory costs of ground-water samples meeting all screening criteria collected for determining ambient conditions and compliance-andenforcement purposes, listed by physical properties and major constituent groups, Colorado, 198465

16. Numbers and estimated costs of: all surface-water measurements and analyses; those meeting either the ambient-conditions or the dataavailability criteria; and those meeting both screening criteria, by source of data, Ohio, 198466

17. Numbers and estimated costs of: all ground-water measurements and analyses; those meeting either the ambient-conditions or the dataavailability criteria; and those meeting both screening criteria, by source of data, Ohio, 198467

18. Numbers and estimated costs of: surface-water-sample analyses meeting both the ambient-conditions and the data-availability criteria and either the location, quality-assurance, or the computerization criteria; and those meeting all five criteria, by source of data, Ohio, 198468

19. Numbers and estimated costs of: ground-water-sample analyses meeting both the ambient conditions and the data-availability criteria and either the location, quality-assurance, or the computerization criteria; and those meeting all five criteria, by source of data, Ohio, 198469

20. Estimated laboratory costs of surface-water samples meeting all screening criteria collected for determining ambient conditions and compliance-andenforcement purposes, listed by physical properties and major constituent groups, Ohio, 198470

21. Estimated laboratory costs of ground-water samples meeting all screening criteria collected for determining ambient conditions and compliance-andenforcement purposes, listed by physical properties and major constituent groups, Ohio, 198471 


\section{GLOSSARY}

The following are definitions of selected technical terms as they are used in this report; they are not necessarily the only valid definitions for these terms. Terms defined in this glossary are in bold print where first used in the main body of this report. ambient conditions. - Conditions that are representative of the general, prevailing water quality of a given stream reach or area of an aquifer. Ambient conditions may or may not include effects of human activities.

analysis. - A laboratory procedure performed on a water sample to determine the proportion or concentration of the total, dissolved, or suspended constituents.

biota.-Flora and fauna occurring in a region (such as bacteria, algae, invertebrates, and other organisms); in this report, refers to organisms found in streams, lakes, or other water bodies, and in the case of aquifers, bacteria.

compliance and enforcement.-Water-quality data-collection activities that are undertaken by a regulatory agency to insure that a permit or other statutory requirement is met.

data base. - An assemblage of water-quality information collected by an agency or institution and maintained in computer files or as paper records.

effluent. - Treated or untreated waste material discharged into the environment. Examples include discharges from water or wastewater-treatment plants, industrial complexes, or landfills.

inorganic constituents. - Combinations of elements that do not include organic carbon.

major metals. - Metals that occur naturally in concentrations greater than 1 milligram per liter; in this report, either or both of the constituents, iron and manganese.

near-natural. - Conditions under which effects of human activities are less than effects of natural processes; the extreme (natural) condition is the absence of discernible human effects.

nutrients. - Any substance that is assimilated by organisms and promotes growth; generally applied to any or all of the constituents that contain nitrogen or phosphorus, such as ammonia, nitrite, or orthophosphate.

organic substances. - Any or all of the groups of compounds containing carbon as identified by tests for the following: organic and inorganic carbon, oil and grease, Biochemical Oxygen Demand, detergents, tannin and lignin, phenols, and similar compounds such as pesticides. permit-required. - Water-quality data-collection activities that are undertaken by a permit holder in partial fulfillment of the legal requirements of a permit allowing the discharge of effluent or other modified waters. Waterquality monitoring mandated by a National Pollution Discharge Elimination System (NPDES) permit issued to a point-source discharger is an example of a permitrequired data-collection activity.

pesticides.-Any of the specific organic compounds used to kill insect or plant pests, such as organochlorine insecticides or triazine herbicides.

physical properties. - Water properties that are characterized by measurements such as: temperature, $\mathrm{pH}$, dissolved oxygen, turbidity, alkalinity, and specific conductance. These measurements generally are made at a data-collection site but may also be measured in a laboratory.

priority pollutants.-Organic compounds comprising any or all of the following pollutant groups: acid- and baseextractable compounds, volatile compounds, and other groups as identified by the U.S. Environmental Protection Agency.

quality assurance.-Testing that encompasses all facets of data collection, laboratory analysis, and reporting for establishing the reliability of results.

radiochemicals.-Constituents whose presence is indicated by the measurement of gross-alpha radioactivity and by tests for specific radioactive elements.

salinity.-A measure of the concentration of dissolved mineral substances in water, particularly salts containing sodium or chloride.

sample.-A volume of water, collected from and representative of a stream, lake, aquifer, or effluent discharge, that may be measured for a number of different properties or that may be analyzed for a number of different constituents, or both.

sediment.-Any or all of the following particulate matter in water: suspended sediment, bed material, bed load, and total sediment load.

trace elements.-Metals and similar elements that routinely occur in nature in concentrations less than 1 milligram per liter, including any or all of the following: aluminum, arsenic, chromium, copper, lead, mercury, nickel, selenium, zinc, and similar elements. 


\title{
Water-Quality Data-Collection Activities in Colorado and Ohio: Phase I-Inventory and Evaluation of 1984 Programs and Costs
}

\author{
By Janet Hren, Thomas H. Chaney, J. Michael Norris, and Carolyn J. Oblinger Childress
}

\section{EXECUTIVE SUMMARY}

Serious questions have been raised by Congress about the usefulness of water-quality data for addressing issues of regional and national scope and, especially, for characterizing the current quality of the Nation's streams and ground water. In response, the U.S. Geological Survey has undertaken a pilot study in Colorado and Ohio to: (1) Determine the characteristics of current water-quality data-collection activities of Federal, State, and local agencies, and universities; and (2) determine how well the data from these activities, collected for various purposes and using different procedures, can be used to improve our ability to answer major broad-scope questions such as:

1. What are (were) near-natural water-quality conditions?

2. What are the existing water-quality conditions?

3. How has water quality changed, and how do the changes relate to human activities?

Colorado and Ohio were chosen for the pilot study because they represent regions with different types of water-quality issues and programs. The results of the study are specific to the two States and are not intended to be extrapolated to other States.

The study has been divided into three phases whose objectives are: Phase I-identify and inventory 1984 waterquality data-collection programs, including costs, in Colorado and Ohio, and identify those programs that meet a set of broad criteria appropriate for addressing the types of broad-scope questions listed above.

Phase II-evaluate the quality assurance of samplecollection techniques and laboratory methods used to compile the data bases that meet Phase I criteria.

Phase III-evaluate the applicability of the data bases, which pass Phase II, to address the listed broad-scope questions for each State; specifically determine for different important water-quality constituents, which of the listed questions can be answered at the Statewide level.

This report presents the results of Phase I by characterizing water-quality data-collection activities during
1984 in Colorado and Ohio. Forty-eight organizations with 115 water-quality data-collection programs were identified in Colorado and 42 organizations with 88 programs were identified in Ohio. Specific information about each of the programs was provided by these organizations by means of a detailed questionnaire. The information was compiled to show: which organizations collect waterquality data; the purposes of water-quality data collection; the types of water-quality determinations; and the cost of water-quality data.

Characteristics of each water-quality data-collection program were compared against a set of five screening criteria:

1. Do the data represent ambient stream or aquifer conditions, as opposed to wastewater effluent or treated water?

2. Are the data available for public use?

3. Can the sampling sites be readily located?

4. Is quality-assurance documentation available?

5. Are the data in computer files?

These criteria were judged to be essential for compiling a data base that would be technically sound, consistent, and readily available for addressing water-quality issues of regional and national scope.

Total costs of water-quality data-collection programs in the two States could not be determined because: (1) Some agencies were unable to provide any estimate of total costs associated with water-quality data-collection activities; and (2) for those agencies which did not provide estimates of total costs, the estimates from agency to agency included widely varying categories of cost, which precluded comparison of the total cost figures. The only reasonable basis for comparison was the numbers of samples and the types of analyses or measurements as reported on the questionnaires. However, reported analytical costs also were incomplete and inconsistent from agency to agency. Therefore, to standardize the comparisons, all costs for laboratory analyses of samples were estimated by multiplying the agency-reported information on numbers and types of samples by the 1984 laboratory prices of the U.S. Geological Survey. 
Major results of Phase I of this study are summarized below and in the accompanying table:

1. Agency involvement-Federal agencies operated the largest group of data-collection programs in each State (see table, box A). Federal programs amounted to about 50 percent of all the programs identified in Colorado and 32 percent of those in Ohio. In addition, many of the State and local programs received funding and other support from Federal agencies. Most of the nonFederal programs were operated by State and local agencies in both Colorado and Ohio. Of the total numbers of samples collected in all programs, most were collected in Colorado by State agencies ( 40 percent) and most in Ohio by local agencies (58 percent).

2. Sources of samples-Most samples from both States were from surface-water sources (see table, box B). Ground-water samples represented only 9 percent of the samples reported from Colorado and 4 percent of those from Ohio. The dominance of surface-water samples reflects a much greater use of surface water than of ground water in both States. The large difference in samples from the two sources also may be due partly to the fact that ground water moves and changes much more slowly than surface water; therefore, less frequent sampling is required to detect changes in ground-water quality. In addition, much of the sampling effort in both States was for mandated purposes, such as meeting permit requirements for monitoring wastewater effluent or drinking water (table, box C). Most of these permits involve surface waters and require repetitive sampling. In total, about four times more samples were reported for Ohio than for Colorado (box D), principally because there are more National Pollution Discharge Elimination System (NPDES) permits in Ohio.

3. Data-collection purposes-The identified organizations collected water-quality data in response to various mandates and for various purposes, which are summarized into three general categories: (1) To meet permit requirements; (2) to fulfill compliance-andenforcement needs; and (3) to characterize ambient waterquality conditions (see table). The data-collection purposes largely dictated where samples were collected, frequency of sampling, methods used, and the water-quality properties and constituents analyzed. These data attributes, in turn, affect the availability and applicability of the data for broad-scale studies. As the table shows (box C), the purpose for which most samples were collected (46 percent in Colorado and 84 percent in Ohio) was to meet permit requirements. None of the samples from those permit-required programs passed the aforementioned screening step, mostly because of failure to meet the ambient-water criterion (see above).

Water-quality analyses resulting from permitrequired sampling, by themselves, generally are not considered useful for assessing water-quality conditions because they represent effluent or treated-water conditions rather than ambient stream or aquifer conditions. However, when used with predictive techniques and in conjunction with instream water-quality data, these analyses are useful for conducting certain water-quality evaluations. For example, effluent analyses are useful for modeling certain constituents such as dissolved oxygen in specific river reaches for waste-load-allocation studies, and for regional and national water-quality assessments to evaluate alternative wastewater-treatment technologies. However, for many other constituents and compounds, such as certain heavy metals and pesticides, knowledge of instream reactions and processes is presently inadequate to enable sound modeling-based assessments. Therefore, permit-required samples were not considered appropriate for inclusion in a data base for defining ambient water-quality conditions and addressing fundamental broad-scope water-quality issues.

4. Property-and-constituent groups-Usefulness of the existing data for addressing critical water-quality issues depends largely on the specific constituents that have been measured. For purposes of this study, eleven major property and constituent groups were evaluated (see table). Of the total number of samples that passed the aforementioned screening step in each State (table, box $G$ ), relatively few were directed at concerns about toxic pollution. For example, the samples for determination of priority pollutants, pesticides, and radiochemicals (box F) amounted to only one-half of a percent of the Colorado samples that passed the screening step and 5 percent of those samples for Ohio. These constituent groups had the three smallest numbers of such samples in each State, partly, no doubt, because these analyses are relatively expensive. In contrast, the physical properties group (box E), for which measurements are relatively inexpensive, was the group with the largest number of post-screening samples in each State.

5. Screening results-Of about one-third million samples reported for Colorado and nearly 1.2 million samples reported for Ohio during 1984 (see table, box D), only a fraction met all the aforementioned screening criteria. The samples that passed the screening step were judged potentially suitable for inclusion in the kind of data base needed for addressing broad-scope waterquality issues (field and laboratory quality assurance of the data bases that passed will be evaluated in Phase II). The samples that met all five of the Phase-I screening criteria comprised 34 percent of the samples reported for Colorado and 5 percent of the Ohio samples. (In the table, compare the numbers in boxes D and G). Most of the data that did not pass the screening step failed because of the ambient-conditions criterion (see above); that is, they did not represent generally prevailing water-quality conditions in the sampled stream or aquifer. 


Selected 1984 data
Numbers and percentages of water-quality
data-collection programs operated by:

A. Federal agencies-...........................

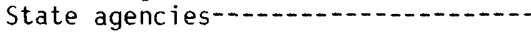

Regional agencies-......................

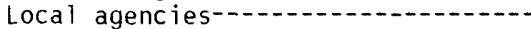
Academic institutions

All identified organizations--.--Approximate numbers and percentages of water-quality samples from:

B. Surface-water sources-.......................

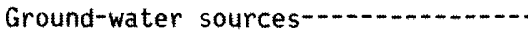

Ground- and surface-water sources (rounded) -..............................

Approximate numbers and percentages of samples for the main purpose of:

C. Meeting permit requirements 1 ......Compliance-and-enforcement activities ${ }^{1}$................................

Characterizing ambient water

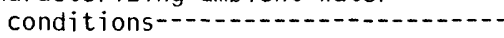

D. Total reported samples (rounded)-.-Approximate numbers and percentages of samples that met Phase-I screening criteria, by major property and constituent groups:

E. Physical properties-a-

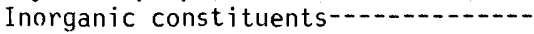

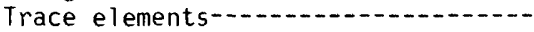

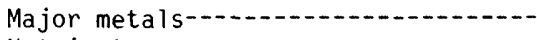
Nutrients--..-..Organic substances--..-..-...-...Priority pollutants

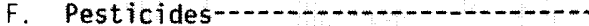
Radiochemicals-....................... Biota--.-.Sediment-1.........

G. All property and constituent groups

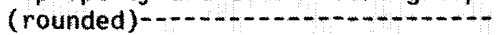

Estimated laboratory costs, before and after Phase-I screening, for samples collected for meeting permit requirements and other purposes (complianceand-enforcement activities, and characterizing ambient water conditions):

Permit-required samples, tota1-.--$H$. Samples meeting screening

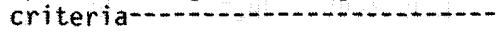

Samples for other purposes, total-Samples meeting screening criteria-

Samples for all purposes, total----

I. Samples meeting screening

criteria--

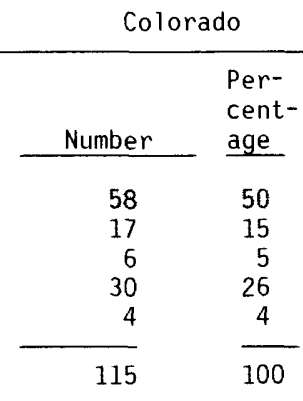

$\begin{array}{rrrr}\begin{array}{rrr}308,120 \\ 30,080\end{array} & 91 & \begin{array}{r}1,146,830 \\ 50,700\end{array} \\ 338,000 & & 100 & 1,198,000\end{array}$

96

4

100

$\begin{array}{rrrr}155,700 & 46 & 1,005,000 & 84 \\ 39,000 & 12 & 15,800 & 1 \\ 143,400 & \frac{42}{100} & \frac{176,700}{1,198,000} & \frac{15}{100}\end{array}$

\begin{tabular}{rrrr}
38,710 & 34 & 12,370 & 22 \\
28,660 & 25 & 7,990 & 14 \\
7,310 & 6 & 5,040 & 9 \\
5,700 & 5 & 3,700 & 6 \\
14,540 & 13 & 8,820 & 16 \\
6,570 & 6 & 4,160 & 7 \\
244 & $<1$ & 1,100 & 2 \\
90 & $<1$ & 1,800 & 3 \\
260 & $<1$ & 50 & $<1$ \\
9,960 & 8 & 4,820 & 8 \\
2,120 & 2 & 7,100 & 13 \\
\hline & - & &
\end{tabular}

84 1

15

100
Per-

centCost

$\$ 6,080,000$

$\$ 0$

$\$ 7,410,000$

$\$ 4,120,000$

$\$ 13,490,000$

$\$ 4,120,000$ age Cost

$45 \$ 35,700,000$

0

$\$ 0$

$55 \$ 13,880,000$

$31 \$ 3,020,000$

$100 \$ \$ 49,580,000$

$31 \$ 3,020,000$

${ }^{1}$ Predominantiy effluent or nonambient samples. 
By placing all water-quality data into computer files (criterion 5, above), the amount of readily available (and otherwise suitable) water-quality data could be increased by 8 percent in Colorado and by 123 percent in Ohio. This large difference between the two States seems to be related to the relative amounts of data collected by each level of government. Federal agencies had a larger role in the collection of water-quality data in Colorado than in Ohio, and the Federal agencies computerized more water-quality data than the local agencies which collected most of the samples in Ohio.

6. Laboratory costs-An estimated $\$ 13.5$ million was spent during 1984 in Colorado and \$49.6 million in Ohio for the laboratory analyses of water-quality samples (see table, box I). Of this, about $\$ 6.1$ million for Colorado and $\$ 35.7$ million for Ohio were spent specifically to meet permit requirements (box $\mathrm{H}$ ). These permit-required samples accounted for 45 percent of the total estimated laboratory costs for Colorado and 72 percent of the total for Ohio. For Colorado, 17 percent of the total estimated laboratory costs was for samples for compliance-and-enforcement activities, and the remaining 38 percent for samples to characterize ambient conditions. For Ohio, 2 percent of the estimated laboratory costs was for compliance-andenforcement activities, and the remaining 26 percent for characterization of ambient conditions. Because of failure to meet the ambient-water screening criterion (criterion 1, see above), the permit-required samples were not included in the post-screening laboratory costs (see box $\mathrm{H}$ ).

Of an estimated \$21.3 million spent on analyses of samples collected to characterize ambient conditions or for compliance-and-enforcement activities in the two States, about $\$ 7.1$ million (box I) represent data from samples that met all Phase-I screening criteria. Thus, only about 11 percent of the total estimated laboratory costs (of \$63.1 million) produced data that are readily available and are considered to be potentially applicable to fundamental broad-scope water-quality issues. These laboratory costs, of course, represent only a part (generally less than 50 percent) of the total costs of the water-quality datacollection programs.

7. Conclusions-The major conclusions resulting from Phase I of this study are:

A. Of the funds spent in 1984 on water-quality datacollection activities in the two States, probably less than half of the funds spent in Colorado, and perhaps as little as one-tenth of the funds spent in Ohio, were applied to activities that produced data suitable for inclusion in the kind of data base needed for addressing water-quality issues of regional or national scope. Moreover, these estimates are likely to be revised downward after further evaluation during later phases of this study.

B. Of the 1984 data that are potentially appropriate (pending further evaluation) for such a fundamental data base, by far the largest amounts pertain to surface water (91 percent in Colorado; 96 percent in Ohio) in contrast to the ground waters (only 9 percent in Colorado; 4 percent in Ohio). This raises questions about whether the distribution of data-collection efforts will be appropriate to meet growing concerns about ground-water quality.

C. The 1984 data that are potentially appropriate for addressing concerns about toxic pollution were very few in comparison to other kinds of available water-quality data. The 1984 data-collection effort to detect and monitor toxic pollution may require modification in view of growing concerns about this major water-quality issue.

D. Although comparative laboratory costs were estimated (see item 6, above), determination of total costs for the water-quality data collections in the two States proved to be impossible within the scope of this study. Reliable, consistent estimates of total program costs would require detailed knowledge of the different appropriations, cost allocations, and accounting practices of each agency which operates data-collection programs.

E. Although the results of this study are specific to the two States and are not intended for extrapolation to other States, certain conclusions from Phase I can be used to guide similar studies for water-quality data collection in other States:

- Permit-required data-collection programs are likely to produce few, if any, data representing ambient water conditions and, therefore (in the judgment of the writers), to yield data suitable for inclusion in the kind of data base needed to define ambient water-quality conditions and to address broad-scope issues concerning the condition of and changes in water quality.

- Any efforts to obtain consistent information about total program costs of water-quality data-collection programs are likely to be greatly hampered by major differences in fund-allocation and accounting practices among the various agencies.

- Special attention may be needed, in other States as in Colorado and Ohio, as to the adequacy of datacollection activities for determining and (or) monitoring: (1) Ground-water quality, and (2) water pollution by toxic substances.

\section{INTRODUCTION}

Increasing concerns about the quality of the surfaceand ground-water resources in the United States have led to water-related Federal legislation such as the Clean Water Act (1972, amended 1977, 1981); the Safe Drinking Water Act (1974); the Resource Conservation and Recovery Act 
(1976); the Toxic Substances Control Act (1976); and the Comprehensive Environmental Response, Compensation, and Liability Act (1980). Billions of dollars have been spent by various agencies on different types of waterquality data-collection programs in support of this legislation and for various other purposes. In recent years, there has been considerable interest by Congress in assessing the effects of human activities and pollution-control programs on water quality, and in the programs designed to monitor water quality. In 1983, the U.S. House of Representatives Subcommittee on Natural Resources, Agriculture Research, and Environment held hearings on national environmental monitoring. At these hearings, monitoring programs were criticized as "fragmented, duplicative, and wasteful, and in many cases, ... devoid of scientific validity and leadership" (Blodgett, 1983, p. 3).

Insufficient information has been available to determine whether these criticisms are accurate. Accordingly, the U.S. Geological Survey has undertaken a pilot study in Colorado and Ohio to determine the extent to which existing water data can be aggregated into a consistent and technically sound data base that is appropriate for waterquality assessments of regional and national scope. This report is the first in a series that describes the pilot study.

\section{Background}

The term "water-quality data" can include a wide array of data on physical, chemical, and biological characteristics, which generally are defined in terms of the intended water use. Drinking-water supply, industrial uses, irrigation, recreation, and habitat for aquatic life are among the water uses that usually require a certain standard of water quality. These water uses may also, in turn, affect the quality of water in streams, lakes, and aquifers.

Water-quality data are collected by various Federal, State, regional, and local agencies, and by academic institutions and private-sector organizations for different purposes or mandates. Many of these water-quality programs focus on specific geographical areas with known or suspected pollution issues. Examples of water-quality data-collection programs include: (1) End-of-pipe sampling of wastewater effluent ${ }^{1}$ required by National Pollution Discharge Elimination System (NPDES) permits; (2) sampling of effluent, streams, or ground water to determine compliance with water-quality criteria and standards established by Federal or State legislation; and (3) sampling to define ambient water-quality conditions

\footnotetext{
${ }^{1}$ To assist readers who may not be familiar with all the technical terms associated with water-quality studies, a brief glossary is provided before the main part of this report. Terms defined in the glossary are in bold print where first used in the main body of the report.
}

and trends by means of fixed-station, fixed-interval networks.

Emphasis on the use of and the needs for waterquality data has changed with time. In many streams, serious surface-water-quality problems of the past, such as decreased concentrations of dissolved oxygen and large bacteria counts, seem to be much less extensive today as a result of pollution-control programs of recent years; however, concerns are increasing about the contribution to pollution from nonpoint sources (agriculture, mining, and urbanization) and the pollution of surface and ground water by synthetic organic chemicals and potentially toxic metals (fig. 1). As new concerns have arisen, many agencies involved in water-quality data collection have adjusted their programs, sometimes changing the location of sampling sites, the frequency of data collection, or the constituents to be identified. These changes are determined by the new issues of concern and an agency's mission, responsibilities, and available resources.

\section{Project Objectives and Approach}

The objective of this study is to determine the extent to which existing water data, collected by different groups for various purposes and using different procedures, can be aggregated into a consistent data base for use in addressing selected water-quality questions of regional and national scope. Examples of such questions are:

1. What are (were) near-natural water-quality conditions?

2. What are existing water-quality conditions?

3. How has water quality changed, and how do the changes relate to human activity?

Many kinds of available data contribute to an understanding of regional and, therefore, national waterquality conditions. For example, loads of dissolved and suspended constituents in a stream may be estimated with the use of data on loads from individual point sources (for example, effluents and tributaries). Similarly, effluent data can be used in mathematical models to simulate water-quality conditions in streams and to evaluate alternative wastewater-treatment technologies for certain constituents. In those and many other studies, however, certain background information or assumptions about the receiving stream are almost always needed. For example, information on nonpoint-source loads is usually unavailable and certain assumptions must be made regarding the magnitude of these loads to simulate water-quality conditions.

One of the most fundamental kinds of background information reflects instream conditions (or ground-water conditions) and processes independent of the effects of human activities under study (see "ambient conditions", 

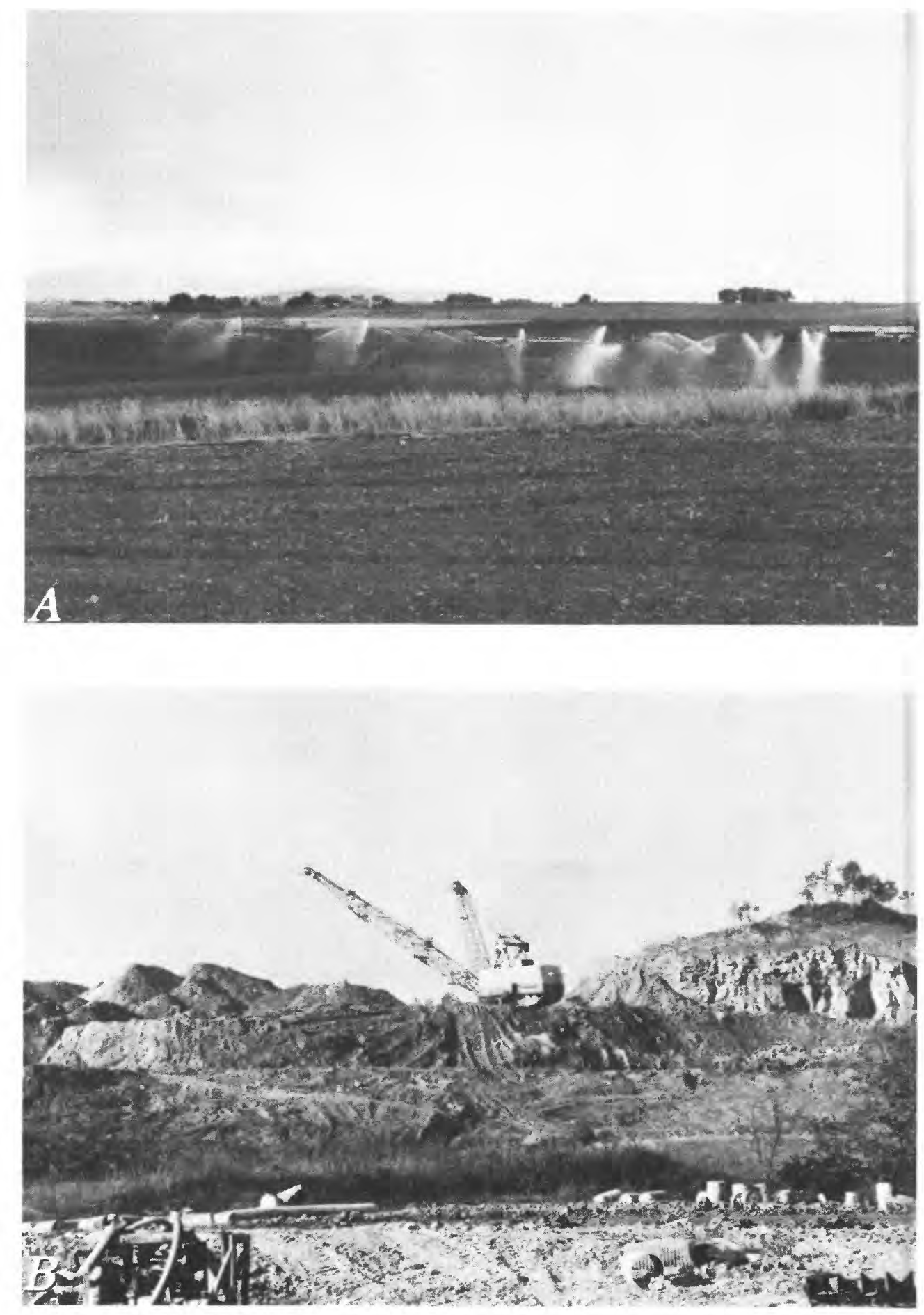

Figure 1. Different land uses that can affect water quality: (A), Crop irrigation in eastern Colorado (photograph by K.E. Cohan, U.S. Geological Survey) and (B), strip mining for coal in eastern Ohio (photograph courtesy of R.P. Frehs, U.S. Geological Survey).

in Glossary). Such backgorund information serves as a solid foundation for a wide variety of water-quality studies, and probably is the most broadly useful kind of information that can be derived from the available water- quality data. Because of its fundamental value, this is the type of information that is stressed in the present evaluation, and is the major consideration in the selection of the criteria used in the evaluation. 
In this context, the specific goals for this study are:

1. Determine the characteristics of current (1984) water-quality programs, including methods of sample collection, laboratory analysis, and data storage by Federal, State, regional, and local agencies, and by academic institutions;

2. determine costs of water-quality data-collection programs; and

3. evaluate the applicability of existing data for addressing selected water-quality questions of regional and national scope (see above).

A three-phase approach was used. The objectives of these phases are:

Phase I. Identify and inventory water-quality datacollection programs, including costs, and identify those programs that meet a set of criteria for conducting broad-scope waterquality assessments.

Phase II. Evaluate the quality assurance of sampling techniques and laboratory methods used in collecting the data that meet the broad criteria of Phase I.

Phase III. Evaluate the applicability of these qualifying data for addressing selected water-quality questions of regional and national scope.

Two States, Colorado and Ohio, were chosen to serve as a small sampling of the Nation. These States represent regions with different types of water-quality issues and programs. Colorado, which has a population of 3 million (U.S. Bureau of the Census, 1981a), is a lightly industrialized, western State with 36 percent federally owned lands (U.S. Bureau of Land Management, 1983). During 1980, freshwater withdrawals in Colorado were 16 billion gallons per day ( 81 percent surface water; 19 percent ground water) for public supply, rural domestic and livestock, industrial, and irrigation uses (Solley and others, 1983, p. 38). Eighty-eight percent of the water was used for irrigation and 6 percent for industry (thermoelectric and other industries included). Major water-quality issues in Colorado are associated with irrigation return flows (salinity) and minerals mining (sediment and trace elements).

Ohio, which has a population of about 10.8 million (U.S. Bureau of the Census, 1981b), is an industrialized eastern State with about 1 percent federally owned lands (U.S. Bureau of Land Management, 1983). In Ohio, freshwater withdrawals in 1980 were 14 billion gallons per day (93 percent surface water; 7 percent ground water) (Solley and others, 1983, p. 38). Eighty-six percent were for industrial uses (thermoelectric and other industries included) and less than 1 percent for irrigation. Major waterquality issues in Ohio are associated with agricultural runoff (nutrients and pesticides), coal mining (acidity and sediment), urban runoff (bacteria, trace elements, and nutrients), and the potentially toxic trace elements and organic substances sometimes associated with industrial discharge.

\section{Phase-I Purpose and Scope}

The purpose of this report is to characterize current (1984) water-quality data-collection programs and related costs in Colorado and Ohio and to identify those data potentially applicable to and readily available for addressing selected water-quality questions of regional and national scope. The results of the project are specific to the two States and are not intended to be extrapolated to other States.

\section{METHODS OF ACQUIRING, COMPILING, AND EVALUATING INFORMATION}

\section{Description of Questionnaire}

The main source of information for this report was a questionnaire (Supplemental Data section at back of report) developed by the U.S. Geological Survey and completed principally through interviews with public agencies and academic institutions involved in water-quality datacollection activities. The questionnaire contains five main sections. The purpose of the first section was to obtain information on the scope, objectives, and cost of each organization's water-quality data-collection activities. The four remaining sections were designed to obtain information specific to different categories of water-quality data: physical measurements, chemical analyses, biological determinations, and sediment analyses.

Each of the water-quality data-collection categories in the questionnaire is subdivided into specific groups of water-quality properties and constituents. These groups include physical properties, inorganic constituents, trace elements, nutrients, organic substances, radiochemicals, biota, and sediment (see Glossary). The measurements or constituents in each group are shown in the questionnaire (Supplemental Data section). For each group, the questionnaire respondent was asked to identify the number of sites sampled, the types of sites sampled, the frequency of sample collection, and the method of data storage. In compiling the questionnaire responses, it was deemed necessary to create a new constituent group, major metals, by separating out the number of samples in the traceelement group that included iron or manganese, or both, either alone or in combination with the other trace elements. Consequently, the number of samples presented in the report for the trace-element group excludes all responses that indicated samples analyzed for only iron or manganese or both. This was done to segregate iron 
and manganese from the other potentially more toxic elements included in the trace-element group. Also, the organic constituent responses were compiled in the following categories: organic substances, priority pollutants, and pesticides. If the "organics all" category was chosen by the questionnaire respondent, the total number of samples that were so reported was arbitrarily divided equally among the three groups. Information on laboratory quality-assurance procedures for each program also was obtained for each of the four major waterquality data-collection categories.

\section{Identification of Organizations Collecting Water- Quality Data}

Organizations contacted as part of the inventory included Federal, State, regional, and local agencies, and academic institutions. Private-sector organizations generally were excluded, mainly because of the proprietary nature of many of the data collected by these organizations, but also because of difficulties in identifying active groups. However, private-sector organizations' sampling activities that were required as part of a water-quality permit program are included in the totals presented here when that total includes permit-required sampling activities.

Organizations contacted in this inventory were identified by membership in State water organizations, participation in the U.S. Geological Survey's Federal-State cooperative program, participation in the National Water Data Exchange (NAWDEX) program (Cable, 1982), and by State publications. To help ensure consistency between the two States, all municipalities with a population greater than 25,000 were contacted in both States. A number of counties, smaller communities, and semi-public water organizations are included in the local government category with these municipalities in both States. In Ohio, programs undertaking sampling activities in Lake Erie were not included.

A separate questionnaire was completed for each data-collection program active during 1984. For this purpose, a water-quality data-collection program was defined as a set of water-quality data-collection activities with an identifiable budget and objectives. Identified program managers were contacted by U.S. Geological Survey personnel by telephone or in person; then the questionnaire was provided to the program manager. A list of organizations for which questionnaires were completed and the constituent groups for which they collected data are presented in table 7 for Colorado and in table 8 for Ohio, in the Supplemental Data section. Questionnaires were completed for more than $\mathbf{9 5}$ percent of the water-quality data-collection programs identified in each State. Instructions that were supplied for completing the questionnaire are in the "Supplemental Data" section at the back of the report.

The inventory includes data-collection activities associated with permit requirements, compliance-andenforcement regulations, and characterization of ambient water quality. Water-quality analyses resulting from permit-required sampling, by themselves, generally are not considered useful for assessing ambient water quality because they represent effluent water conditions rather than ambient stream or aquifer conditions. However, when used with predictive techniques and in conjunction with instream water-quality data, effluent analyses are useful for conducting certain water-quality evaluations. For example, effluent analyses are useful for modeling certain constituents such as dissolved oxygen in specific river reaches for waste-load-allocation studies and for regional and national water-quality assessments to evaluate alternative wastewater-treatment technology. However, for many other constituents such as certain heavy metals and organic compounds, current knowledge of instream reactions and processes is inadequate for modeling. Therefore, once identified from the questionnaires, the permit-required analyses might have been excluded from further consideration in this study. It was obvious from the questionnaire returns, however, that permit-required programs constitute a major part of the water-quality data-collection programs in each State, and to eliminate them altogether would leave an incomplete view of the 1984 level of effort in water-quality monitoring. Also, the permit-related programs are needed for comparative cost evaluation. Accordingly, the information about the permit-required programs is included where required for completeness and comparative purposes, and is excluded from some of the later evaluations, where it would be inappropriate. The inclusion or exclusion of the permit-related data is indicated for each evaluation step. Permit-related activities were tallied differently from all other activities. The large number of individual permits in each State and the individual sampling requirements stipulated in each permit precluded the completion of a separate questionnaire for each permit. Instead, a permit program had one questionnaire completed for each type of permit, as required by the permit regulations. For example, two questionnaires were completed in each State for the National Pollution Discharge Elimination System (NPDES) permit program-one for municipal-discharge permits and a second for industrialdischarge permits. The information about permit programs varies from program to program and its consistency depends largely on the comparability of the sampling requirements contained in each permit. The permit programs most affected by this inconsistency, in both States, were the NPDES industrial-permit programs, because each permit's requirements are determined according to the characteristics of the individual wastewater discharge. 


\section{Determination of Water-Quality Data Costs}

An original objective of this phase of the study was to determine the total program costs for the water-quality data-collection programs in the two States. Total program costs might be expected to include the costs for such elements as travel for sampling, shipment of samples, salaries of field or laboratory personnel or both, laboratory analyses, amortization of equipment, administrative overhead, and maintenance of a data file or reporting system or both. The 1984 total program costs were requested in section I.8.0 of the questionnaire (see Supplemental Data section).

The questionnaire responses, however, did not yield adequate information about total program costs. About one-third of the completed questionnaires lacked any type of cost information. Seventy-five percent of the questionnaires completed in Colorado reported total program costs, which amounted to about $\$ 6$ million. For Ohio, 59 percent of the questionnaires reported total program costs amounting to $\$ 10.7$ million. Also, the responses received were variable in detail. Some included most of the cost elements listed above, while others included only salaries or only laboratory costs.

To provide a more consistent basis for comparing the cost of water-quality data-collection activities, estimates of laboratory expenses were developed. These estimates were based on the numbers of samples and the types of determinations or analyses reported by the questionnaires.

Charges by the principal U.S. Geological Survey laboratories for determining individual water-quality properties and constituent concentrations, as identified in the agency's 1984 laboratory-services catalog (Feltz and others, 1983), were used as the cost per sample. Those principal laboratories (in Denver and Atlanta) do not perform several of the analyses identified in the questionnaire; therefore, costs for these other analyses were obtained from the U.S. Geological Survey laboratory in Columbus, Ohio.

In developing the estimated laboratory costs for the reported programs, questionnaire responses for each of the physical property and constituent groups were examined to determine which specific properties and constituents were reported most frequently. The most frequently reported properties and constituents in each group were then used to develop a typical suite of properties and constituents for that group. Because more than one analytical method may be available to measure a property or constituent, the cost of the most commonly used method during the previous 12 months at the U.S. Geological Survey's laboratory in Denver was used. The costs of performing these individual analyses were totaled for each set of properties and constituents. This total was then multiplied by the total number of samples per year reported for that property or constituent group. The result was the estimated yearly laboratory cost for all samples in that property or constituent group. The analyses used for the cost estimates and their associated costs are shown in table 9 in the Supplemental Data section.

The U.S. Geological Survey laboratory costs for each of the property and constituent groups were compared to the cost of comparable analyses for a number of other public and private laboratories in both Colorado and Ohio. When all available laboratory costs were compared, U.S. Geological Survey costs were consistently in the middle to lower half of the range of costs.

The laboratory costs for analyzing different properties or constituents varied greatly depending on the specific constituent. For instance, a single pesticide analysis may cost considerably more than several inorganic analyses. The estimated laboratory-costs procedure was used in part to reflect these cost differentials.

Estimating costs of permit-required data-collection programs presented special problems. As previously stated, sampling requirements vary from permit to permit. With more than 6,500 permits, it was impractical to obtain individual sampling requirements, so the most commonly required constituents were assumed for all permits. (Industrial, municipal, strip-mine, and drinkingwater permit requirements were calculated separately.)

The laboratory costs constitute only a part, although usually a major part, of the total costs of a water-quality data-collection program. To gain a better insight into the relation between laboratory costs and total program costs, water-quality programs of the U.S. Geological Survey in the two States were examined. These total program costs commonly included most or all of the cost elements listed before.

In Colorado, 22 U.S. Geological Survey programs reported total costs of about $\$ 1.5$ million. Estimated laboratory costs for these programs were $\$ 527,800$, or 35 percent of total program costs. In Ohio, 13 U.S. Geological Survey programs reported total costs of about $\$ 1$ million. Estimated laboratory costs were $\$ 177,500$, or 18 percent of total program costs. For this agency's programs, as with those of other reporting agencies, laboratory costs varied from program to program depending on the number of samples and types of analyses performed.

\section{Screening Criteria}

Each data base represented by a questionnaire was tested against five broad screening criteria. The purpose of this screening was to provide a preliminary indication of the applicability and availability of the data collected by each program for addressing water-quality questions of regional and national scope. The choice of criteria reflects the potential difficulties involved in combining data from diverse programs in order to develop a water- 
quality data base that covers broad geographical areas, as well as the need for consistent, technically sound, water-quality data. The fact that a program's data did not meet these screening criteria does not mean that the data are not useful for meeting that program's objectives or that they could not be used for water-quality studies with objectives different from those stated for this study. The screening criteria selected were:

1. Do the data represent ambient stream or aquifer conditions, as opposed to effluent or treated water?

2. Are the data available for public use?

3. Can the sampling sites be readily located?

4. Is quality-assurance documentation available?

5. Are the data in a computer file?

Criterion 1 was included to identify those waterquality data collected to describe ambient surface- or ground-water conditions. If the questionnaire responses for a constituent group indicated that the sampling station was for determining general surface- or ground-water conditions, then the station met this criterion. Samples collected at a point of effluent discharge or, in the case of ground water, samples representing seepage from a landfill, are not useful for defining ambient stream or aquifer conditions; therefore, data from those sites were excluded to avoid an undesirable bias in interpreting general water-quality conditions. Also, samples representing treated drinking water were excluded, whereas samples collected before treatment were included.

Accessibility of the data (criterion 2) is a fundamental requirement; if the data are not readily available, obviously they do not constitute reliable input for broad-scope water-quality assessments. A data base met criterion 2 if the "unrestricted" response to question 7.11 of the questionnaire (see Supplemental Data section) was chosen. For any of several reasons, access to some data was restricted, such as data collected for use in litigation.

Sampling-site locations (criterion 3) were judged adequate if the response to question 7.10 of the questionnaire indicated that a site's latitude and longitude were known or that the location could be obtained from a map. Adequate locations not only are needed to define the part of a stream or aquifer system represented by a water sample, but also are essential for judging the comparability of data from the same general area.

Quality-assurance procedures (criterion 4) are essential to ensure the validity and reliability of water-quality data and to help determine comparability of data from different sources. A program met this criterion if the response indicated that any of the quality-assurance options identified in the questionnaire were used in the program. (In Phase II, a more detailed evaluation of the programs' sample-collection techniques, quality-assurance procedures, and laboratory-analytical methods will be undertaken.)
Criterion 5, computerized storage of data, was included for practical reasons. A program's data, of course, may be of excellent quality whether or not they are stored in computer files. However, the compilation and manipulation of large volumes of data needed for regional or national assessments are infeasible unless these data are stored in computer files for ready accessibility.

The screening process, using these five criteria, provided a preliminary indication of how many of the existing water-quality data presently collected by a wide variety of organizations are potentially applicable to and readily available for addressing water-quality questions of regional and national scope. In the ensuing evaluation, the data that met criterion 1 (ambient conditions) and 2 (data availability) are presented separately from those that met criteria 3, 4, and 5. A distinction is made between these two sets of criteria to highlight water-quality program elements that might be modified readily in the future to increase the quantity of applicable data. Programs having a mandate to sample effluent or other modified waters, or to keep the data confidential, may not be able to readily change these constraints and, therefore, have little possibility of contributing to the broader data base in the future. Conversely, water-quality data-collection programs that did not have adequate site locations, adequate quality-assurance procedures, or did not computerize their data possibly could do so in the future, thereby increasing the quantity of data applicable to and readily available for regional or national assessments.

\section{ORGANIZATIONS COLLECTING WATER-QUALITY DATA}

Several of the various organizations that collect water-quality data conduct several different types of datacollection programs to meet various responsibilities or mandates. The purposes may include water-quality regulation, pollution control, planning, research, policy making, and resource assessment. The variety of purposes for which water-quality data are used also results in a wide variety of types and amounts of data that are collected. The number of programs, therefore, does not totally reflect an organization's degree of effort. The degree of effort associated with each program is defined herein as a function of the number of data-collection sites and the number of samples collected per year at each site. This section summarizes the number of organizations collecting water-quality data, and their degree of effort, in Colorado and Ohio during 1984.

\section{Colorado}

More than 150 organizations in Colorado were contacted as part of this inventory. Forty-eight of these 
Table 1. Numbers of organizations reporting water-quality data-collection programs and numbers of programs reported, Colorado, $1984^{1}$

\begin{tabular}{|c|c|c|c|}
\hline \multicolumn{2}{|c|}{ Organizational categories } & \multirow{2}{*}{$\begin{array}{c}\begin{array}{c}\text { Number of } \\
\text { organizations } \\
\text { reporting programs }\end{array} \\
1\end{array}$} & \multirow{2}{*}{$\begin{array}{c}\begin{array}{c}\text { Total } \\
\text { number of } \\
\text { programs }\end{array} \\
22\end{array}$} \\
\hline Federal: & U.S. Geological Survey. & & \\
\hline & $\begin{array}{l}\text { Other Department of the } \\
\text { Interior agencies. }\end{array}$ & 4 & 18 \\
\hline & $\begin{array}{l}\text { U.S. Envi ronmenta] } \\
\text { Protection Agency. }\end{array}$ & 1 & 3 \\
\hline & Other Federal agencies. & 6 & 15 \\
\hline & Total, Federal agencies. & 12 & 58 \\
\hline State: & $\begin{array}{l}\text { Colorado Department of } \\
\text { Health. }\end{array}$ & 1 & 13 \\
\hline & Other State agencies. & 2 & 4 \\
\hline & Total, State agencies. & 3 & 17 \\
\hline Regional: & $\begin{array}{l}\text { Total, regional agencies. } \\
\text { (Intrastate) }\end{array}$ & 3 & 6 \\
\hline Local: & Total, local agencies. & 27 & 30 \\
\hline \multicolumn{2}{|c|}{ Academic institutions. } & 3 & 4 \\
\hline & Total, all organizations. & 48 & 115 \\
\hline
\end{tabular}

\footnotetext{
${ }_{1}^{1}$ Permit-required programs are ascribed to the organization responsible for their implementation, irrespective of funding sources.
}

organizations conducted 115 water-quality data-collection programs during 1984 (table 1). Federal government agencies were responsible for 50 percent of all identified active water-quality data-collection programs. Local agencies were responsible for the second largest number of programs ( 26 percent). State agencies were responsible for 15 percent of all programs. Regional (interstate) agencies and academic institutions were responsible for 9 percent of the programs.
Organizations in Colorado with water-quality datacollection programs are listed in table 7 (Supplemental Data section). At the Federal level, data-collection activities are divided among 12 different agencies. The Department of the Interior had the largest number of agencies (5) collecting water-quality data. The Colorado Department of Health was the principal State agency collecting water-quality data.

The percentages of samples, both surface and 
ground water, reported by each level of government and by academic institutions for Colorado are summarized in figure $2 A$. Although Federal agencies had the largest number of programs, they reported only 24 percent of the samples. State agencies reported the greatest number of samples (40 percent). This large number of samples reported by the State agencies is an indication of the variety of programs they must maintain and the fact that their responsibilities are statewide.

\section{Ohio}

More than 200 organizations-including Federal, State, regional, county, and municipal agencies-and academic institutions were contacted in Ohio.

Forty-two of these organizations conducted active water-quality data-collection programs during 1984 (table 2), accounting for 88 individual programs. (Programs associated with data-collection activities for Lake Erie were not included in this study.)

Federal, State, and local agencies had similar numbers of water-quality data-collection programs and, together, they were responsible for 88 percent of the total programs. Academic institutions and regional agencies were responsible for the remaining 12 percent of the programs. The Ohio Environmental Protection Agency, with 17 programs, had the largest number of programs for an individual organization, followed by the U.S. Geological Survey with 13 programs. The water-quality datacollection programs undertaken by the different organizations are listed in table 8 (Supplemental Data section).

The percentage of samples, both surface and ground water, collected by each organizational category is summarized in figure 2. Local agencies reported the largest number of samples, 58 percent, followed by State agencies, 26 percent. The large number of samples reported by local agencies results primarily from the monitoring of sources of untreated drinking water. Although Federal agencies had the largest number of programs, they account for only 7 percent of the samples reported. The difference between the number of programs and number of samples reported by the different levels of government results from differences in program objectives and the numbers of sampling sites and sampling frequencies required to meet those objectives. For example, the objectives of local agency programs may require that samples be collected daily, whereas, the objectives of Federal programs may require that samples be collected weekly or monthly.

\section{Comparison Between States}

The primary difference in the total number of programs between the two States is the number of Federal
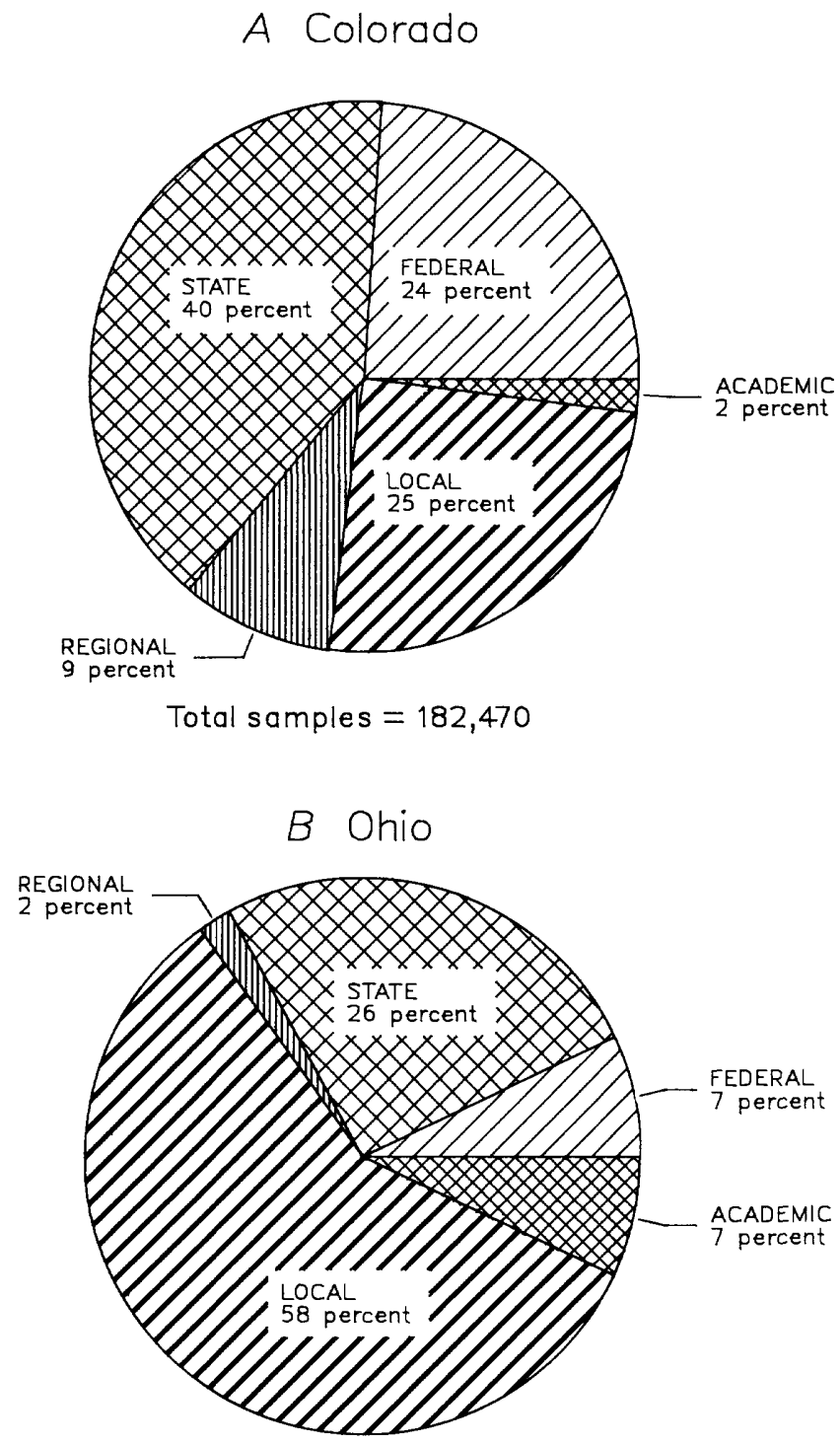

Total samples $=192,560$

Figure 2. Distribution of water-quality samples reported for 1984 by organization category: $(A)$, Colorado and $(B)$, Ohio. (Samples collected to meet permit requirements are not included. See also table 5 .)

programs; 58 are conducted in Colorado and 28 in Ohio. The larger number of Federal programs in Colorado results from the larger Federal land ownership in that State and the management responsibilities associated with this ownership.

In both States, the most active single organization is a State agency: the Colorado Department of Health (38 percent of all samples) in Colorado and the Ohio Environmental Protection Agency (19 percent of all samples) in Ohio. These two organizations have similar 
Table 2. Numbers of organizations reporting water-quality data-collection programs and numbers of programs reported, Ohio $1984^{\prime}$

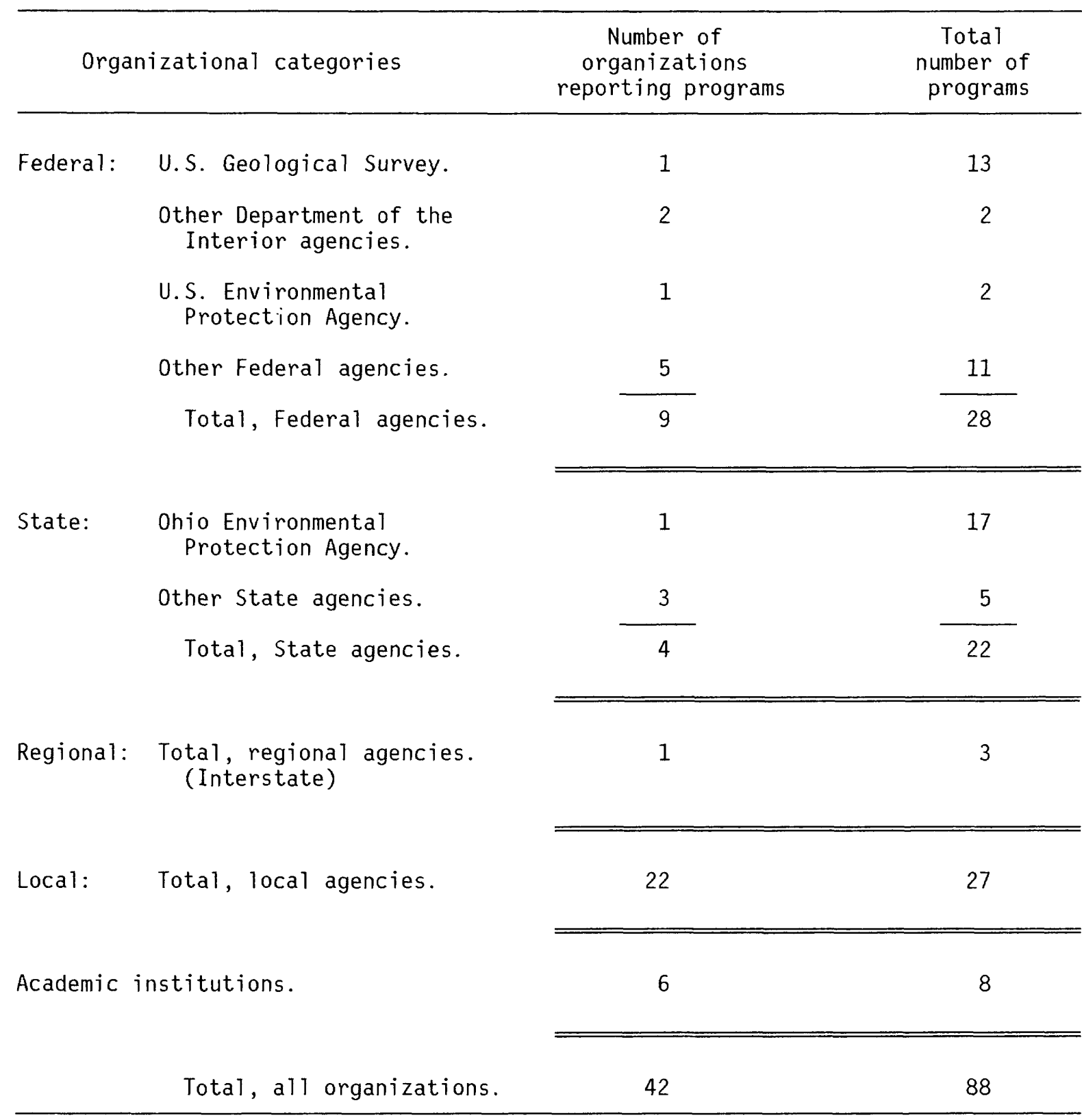

\footnotetext{
1 Permit-required programs are ascribed to the organization responsible for their implementation, irrespective of funding sources.
}

responsibilities as the principal water-quality-management agencies in their respective States.

In both States, the U.S. Geological Survey had more programs and reported more samples than any other Federal agency. The U.S. Environmental Protection Agency had very few active water-quality datacollection programs in either Colorado or Ohio; however, that agency oversees many water-quality data-collection activities in these States and is responsible for reviewing and approving State water-quality-management activities.

\section{PURPOSES OF WATER-QUALITY DATA COLLECTION}

Water-quality data, as mentioned previously, were collected for a variety of reasons. The purpose determined 
where samples were collected, frequency of collection, the methods used, and for which properties and constituents the samples were analyzed. These characteristics, in turn, can affect the applicability and availability of the data for broad-scale studies. For this report, three general categories of purposes have been identified: (1) To meet permit requirements, (2) to fulfill compliance-andenforcement activities, and (3) to characterize ambient water-quality conditions.

\section{Colorado}

More than 338,000 water-quality samples were reported in Colorado during 1984. The distribution of samples reported in each of the three purpose categories is shown in figure 3. Most of the samples reported in Colorado were either required by permit (46 percent) or collected to characterize ambient water-quality conditions (42 percent). Ninety-one percent of all samples were surfacewater samples. Most of the permit samples were collected by municipal and industrial wastewater dischargers to meet NPDES requirements under the Clean Water Act of 1977 (about 1,100 permits) and by drinking-water suppliers to meet the requirements of the Safe Drinking Water Act of 1974 (about 1,650 permits).

\section{Ohio}

About 1.2 million water-quality samples were collected in Ohio during 1984. The distribution of samples reported in Ohio for each of the three purposes are shown in figure $3 B$. Most samples ( 84 percent) were reported to meet permit requirements. There were more than 3,800 active permits in Ohio during 1984, including 1,139 wastewater-discharge permits for industries, 932 for municipalities, 235 for strip mines, as well as 1,550 for public drinking-water supplies. Many permit holders are required to collect samples daily, which accounts for the large number of samples in the permit-required category. Almost all the samples in the permit category were surface water. Fifteen percent of the samples were for characterizing ambient conditions (12 percent surface; 3 percent ground water). Only one percent of all samples were for compliance-and-enforcement activities; most of these were ground-water samples.

\section{Comparison Between States}

The number of samples reported for each purpose in Colorado and Ohio is compared in figure 4. Nearly four times as many samples for all three purposes were reported during 1984 in Ohio as in Colorado. Because of its greater
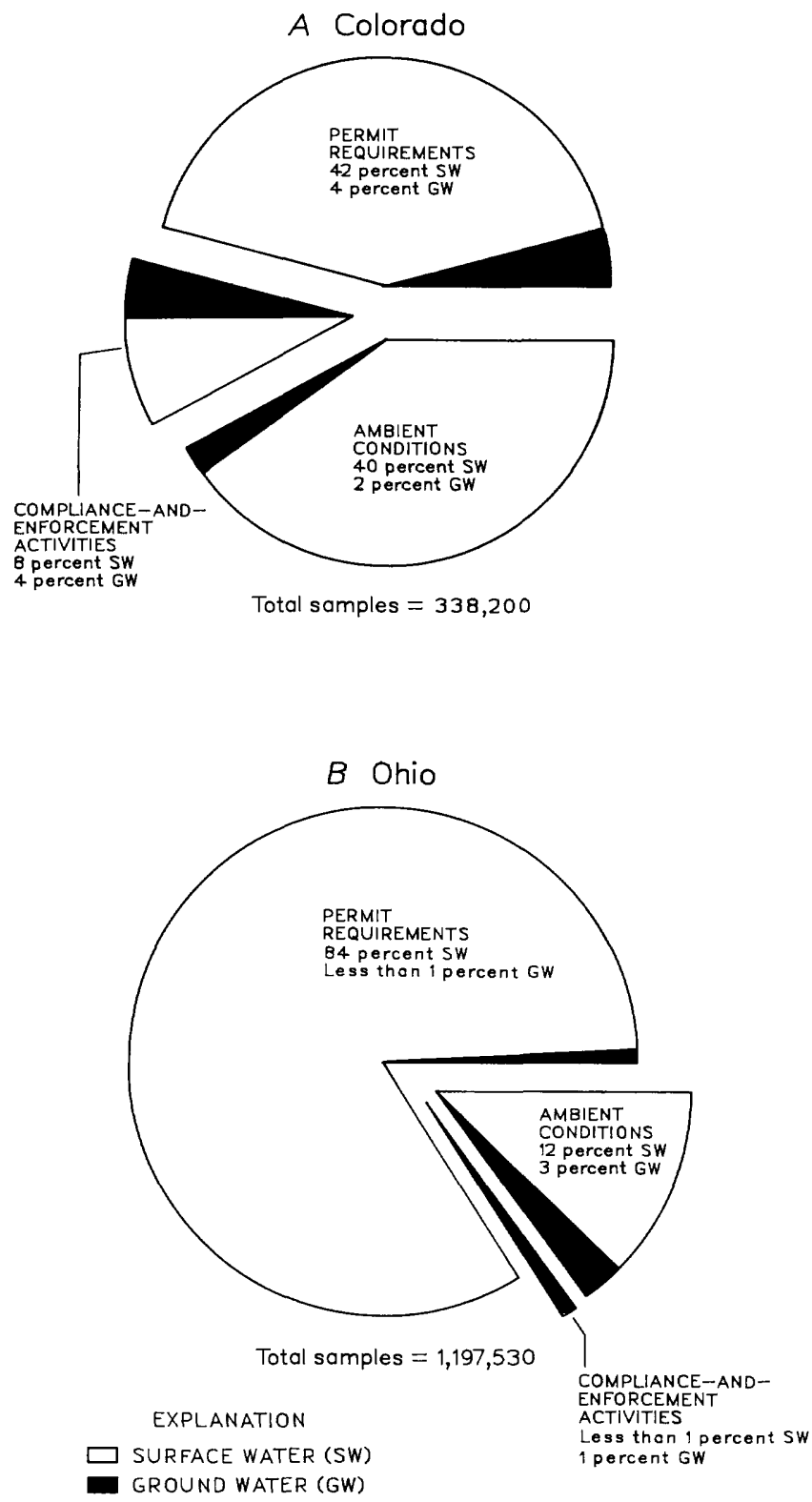

Figure 3. Samples reported for 1984 for the purpose of meeting permit requirements, undertaking compliance-and-enforcement activities, or characterizing ambient conditions: $(A)$, Colorado and $(B)$, Ohio.

industrial activity, Ohio has about 40 percent more permits than Colorado and, therefore, a much larger number of permit-required samples. Also, even though Colorado and Ohio have about the same numbers of drinking-water permits, the permits in Ohio require more frequent sampling than those in Colorado, which further increases the number of permit samples reported in Ohio. The numbers of samples reported for characterizing ambient waterquality conditions are similar in Colorado and Ohio; however, these samples represent 42 percent of all samples reported in Colorado and only 15 percent in Ohio. 


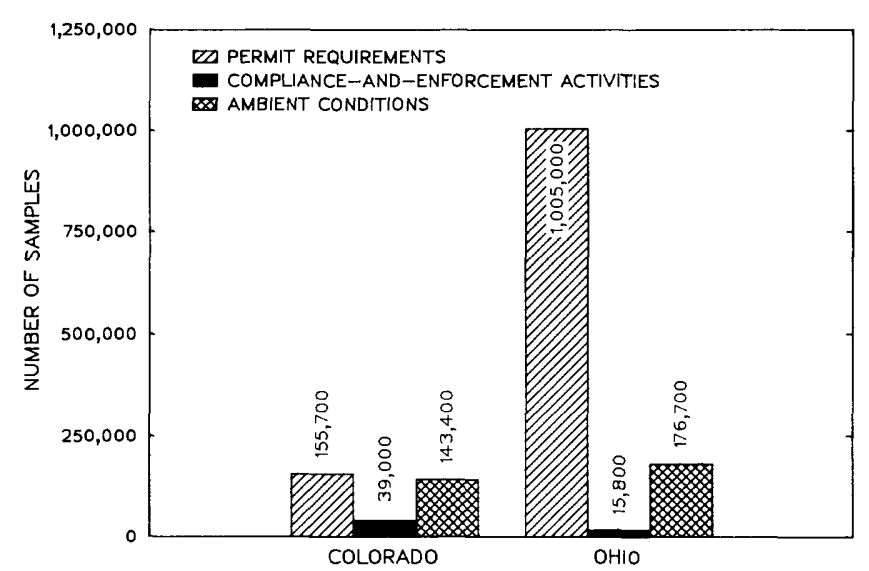

Figure 4. Comparison of the numbers of water-quality samples reported for the purposes of meeting permit requirements, undertaking compliance-and-enforcement activities, or characterizing ambient conditions in Colorado and Ohio, 1984.

In both States, relatively few samples-less than 10 percent-were collected from ground water. This may be due, in part, to the fact that ground water moves very slowly in comparison to surface water; thus, ground-water quality is less likely to change as rapidly as surface-water quality. The difference in sample numbers is also a reflection of the greater usage of surface water in both States. Of the total reported samples, about 20,000 more groundwater samples were collected in Ohio than in Colorado.

\section{TYPES OF WATER-QUALITY DETERMINATIONS}

Individual water samples were analyzed for a variety of specific physical properties and chemical constituents. Different properties and constituents address different problems and have greatly differing costs. For the purpose of this report, these properties and constituents have been categorized into 11 major groups, as described in the section on Methods of Acquiring, Compiling, and Evaluating Information. In addition to these 11 groups, samples also were reported for chemical analysis of sediment and chemical analysis of fish tissue. Although both of these types of data can be useful for interpreting and understanding water quality, the number of these samples reported in both States was very small, and these data are not included in the following compilations.

\section{Colorado}

The numbers of samples analyzed for each of the property and constituent groups in Colorado during 1984 are shown in figure $5 A$ for surface water and in figure $6 A$ for ground water. Samples collected for complianceand-enforcement activities and for characterizing ambient conditions have been grouped together in these figures. For surface water, the physical-properties group had the largest number of samples for all three of the purpose categories. The inorganic constituent group was second. Less than 1 percent of all surface-water samples were collected for the analysis of specific organic compounds as represented by the priority-pollutants and pesticides groups.

The physical-properties and inorganic-constituents groups also were the two largest groups among groundwater samples collected for compliance-and-enforcement and characterizing ambient conditions activities (fig. $6 \mathrm{~A}$ ). Permit-required ground-water samples, however, show a distinctly different distribution. The biota and organic substances constituent groups were first and second in number of permit-required samples. In contrast to surfacewater samples, 12 percent of all ground-water samples were collected for analysis of specific organic compounds represented by priority pollutants and pesticides. (Note that graphs $5 A$ and $6 A$ are not directly comparable because of a tenfold difference in the vertical scales.)

Physical properties such as temperature, $\mathrm{pH}$, and specific conductance are dominant in these totals because they are the least costly analyses, and the resulting data can provide a good preliminary indication of water-quality conditions. Also, automated monitoring equipment enables more frequent measurement of properties such as $\mathrm{pH}$ and specific conductance, which greatly increases the total number of these measurements. In contrast, priority pollutants and pesticides were sampled less frequently, largely because of the relatively high cost of these analyses.

\section{Ohio}

The numbers of samples analyzed for each of the property and constituent groups in Ohio during 1984 is summarized in figure $5 B$ for surface water and in figure $6 B$ for ground water (note difference in vertical scales). The largest numbers of surface-water samples analyzed in both categories were for physical properties (47 percent of permit-required, and 23 percent of complianceand-enforcement plus ambient-condition samples). For ground water, the largest number of analyses for permitrequired samples was trace elements ( 25 percent), while the largest number of analyses for compliance-andenforcement plus ambient-condition samples was biota (24 percent)-mostly bacteriological determinations in untreated drinking-water supplies.

\section{Comparison Between States}

The numbers of samples reported in Colorado and Ohio by major property and constituent groups are 

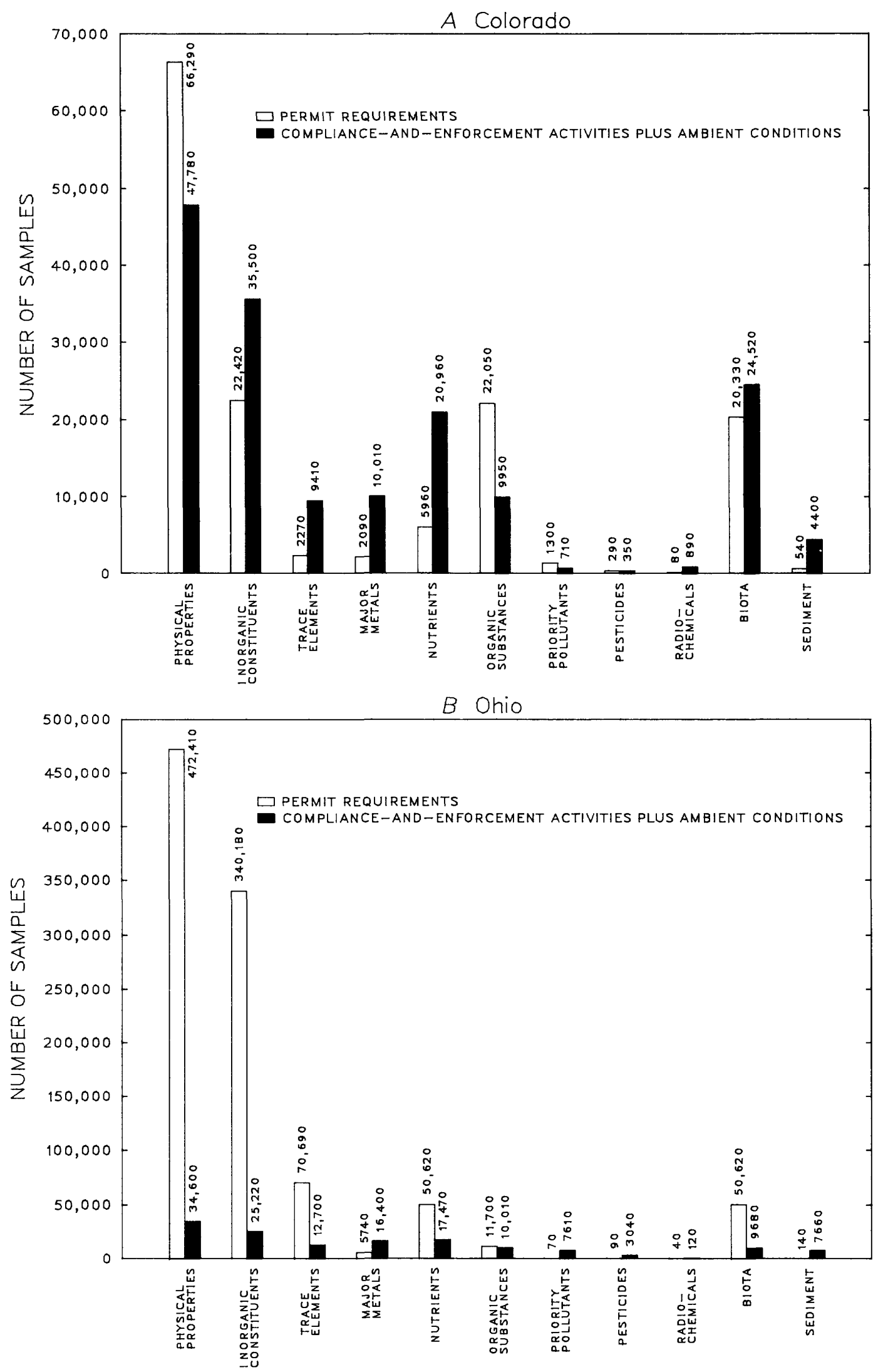

Figure 5. Numbers of surface-water samples reported for 1984 by major property and constituent groups: (A), Colorado and (B), Ohio. (Note difference in bar scales. See Glossary for explanation of constituent groups.) 

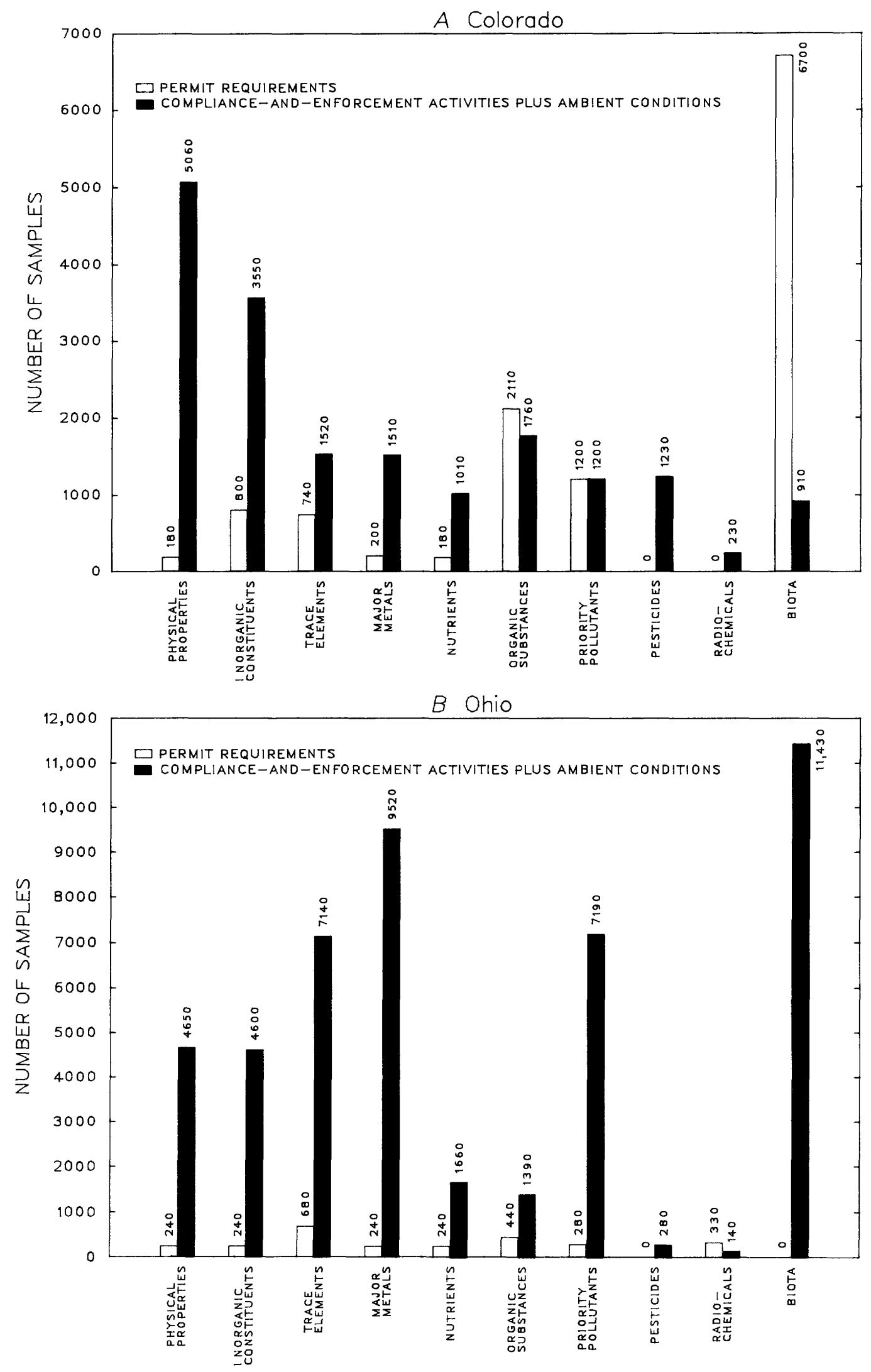

Figure 6. Numbers of ground-water samples reported for 1984 by major property and constituent groups: (A), Colorado and (B), Ohio. (Note difference in bar scales. See Glossary for explanation of constituent groups.) 


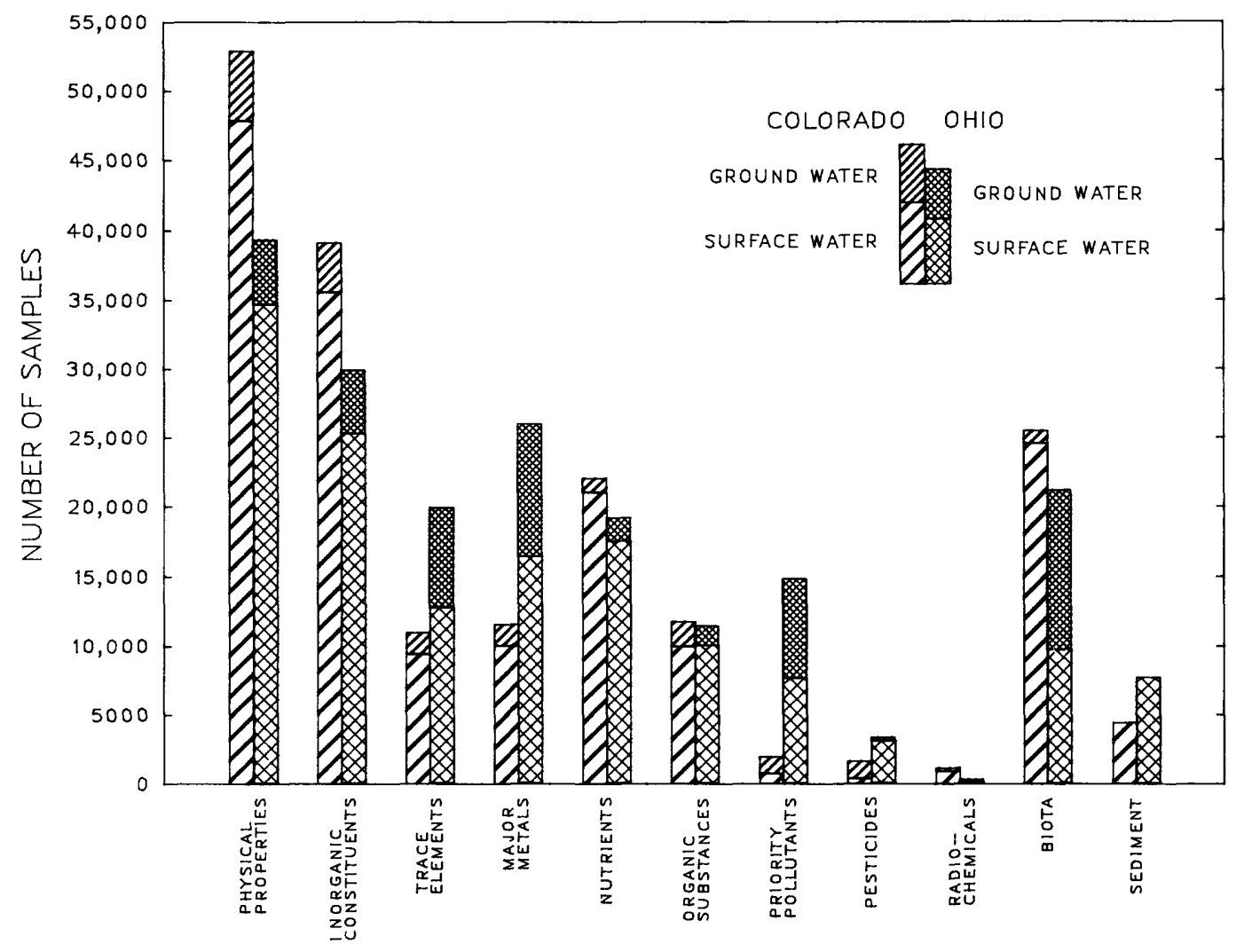

Figure 7. Numbers of surface- and ground-water samples by major property and constituent groups, Colorado and Ohio, 1984. (Samples reported to meet permit requirements are not included.)

compared in figure 7. (Samples collected to meet permit requirements are not included.) The physical-properties constituent group had the largest number of samples in each State-29 percent in Colorado and 20 percent in Ohio. Priority pollutants and pesticides represented only 2 percent of all nonpermit samples collected in Colorado and 9 percent in Ohio. However, these groups represented 14 percent of the ground-water samples in Colorado and 16 percent in Ohio. The greater number of samples analyzed for these constituents in ground water than in surface water is the result of the increasing concern about ground-water pollution by potentially toxic substances and because adequate monitoring of ground water can be accomplished with relatively infrequent sampling.

More samples were analyzed for radiochemical constituents in Colorado than in Ohio, a reflection of the uranium mining in Colorado. Conversely, in Ohio, more samples were analyzed for trace elements, major metals, and priority pollutants than in Colorado, a reflection of the greater industrial activity that may be the source of these constituents in Ohio.

\section{COSTS OF WATER-QUALITY DATA}

Estimated laboratory costs were developed to provide a consistent basis for comparing the cost of data- collection activities for different organizations and constituent groups (see Methods of Acquiring, Compiling, and Evaluating Information). Estimated laboratory costs were developed for the samples collected in the three purpose categories described previously: permit-required, compliance-and-enforcement activities, and ambient conditions. The cost estimates presented herein are ascribed to the organization collecting the samples and expending the funds, as opposed to the organization(s) providing the funds. For example, even though a local data-collection agency received some of its funding from Federal sources, the local agency, rather than the Federal agency that supplied the funds, is listed as the program agency.

\section{Colorado}

Estimated laboratory costs in $\mathbf{1 9 8 4}$ for the different purposes of data collection are shown in figure $8 A$. The total estimated cost of all sample analyses for Colorado, including permit-required sampling, was more than $\$ 13.4$ million. The distribution of these costs is similar to the percentages of samples reported for each purpose (fig. $3 A$ ). Permit-required samples represented the largest percentage of estimated laboratory costs -45 percent. The estimated cost of analyzing the ambient-condition samples was second, with 38 percent of the costs. Samples reported 

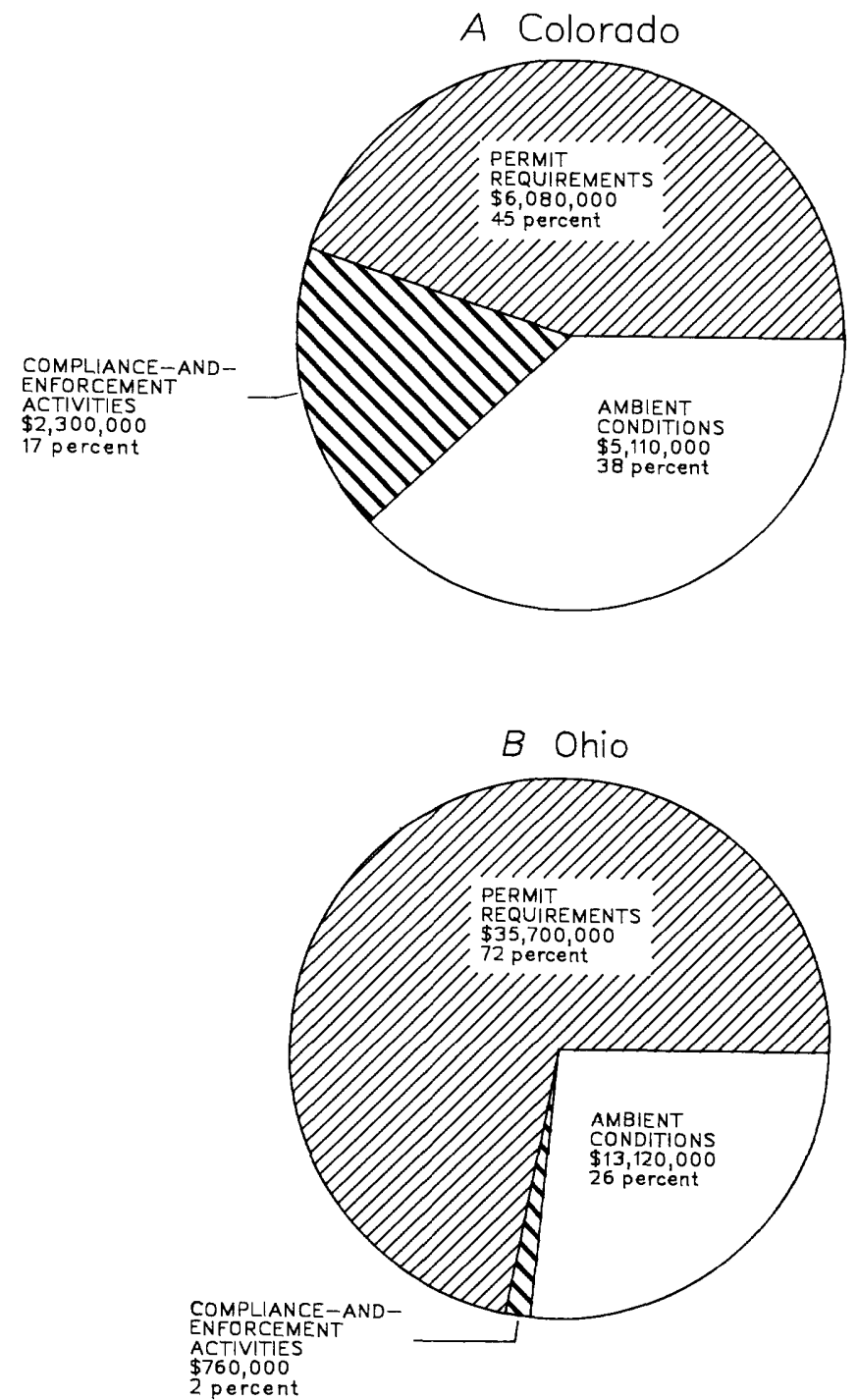

Figure 8. Percentages of estimated laboratory costs for the purposes of meeting permit requirements, undertaking complianceand-enforcement activities, or characterizing ambient conditions during 1984: $(A)$, Colorado and $(B)$, Ohio. Estimates are based on U.S. Geological Survey laboratory costs (table 9).

for compliance-and-enforcement activities represented 17 percent of the estimated laboratory costs.

Estimated laboratory costs for Colorado are shown by organizational category in table 3 . The distribution of total expenditures among the organizational categories is not significantly different from the distribution of the sample totals discussed earlier (see fig. 2). State agencies had the largest total expenditures, followed closely by Federal and then by local agencies. The estimated laboratory costs given individually (table 3 ) for surface-water samples and ground-water samples also reflect the level of activity by each organizational category. State agencies reported the largest number of surface-water samples and also had the largest estimated surface-water laboratory expenditures, and Federal agencies reported the largest number of ground-water samples and had the largest ground-water-related costs (table 3).

The distribution of expenditures between organizational categories and surface and ground water is largely a function of organizational responsibilities. Federal agencies in Colorado at the time of the inventory still had most of the responsibility for identifying and monitoring toxicwaste sites, including those at federal facilities. This resulted in the large proportion of federal ground-water analytical expenditures.

Estimated laboratory costs for each property and constituent group for both surface- and ground-water samples for Colorado are shown in figure $9 A$ (permitrequired samples not included). For surface-water analyses, inorganic constituents accounted for the greatest estimated costs. The physical-properties group, with the largest number of samples (29 percent), accounted for only 11 percent of total surface-water expenditures, because measurements of these properties are relatively inexpensive to obtain. Although the cost per sample to analyze for organic compounds, such as priority pollutants, is expensive, estimated 1984 expenditures for Colorado are small because of the relatively fewer number of samples collected for these analyses.

In contrast to the surface-water samples, the largest estimated laboratory costs for ground-water samples were for priority pollutants and pesticides, which (combined) comprised 14 percent of the samples and 59 percent of the total estimated costs for Colorado ground-water samples. These expenditures can be attributed mainly to sampling undertaken by Federal agencies to monitor for hazardous wastes.

\section{Ohio}

The total estimated laboratory cost of all the reported Ohio samples for both surface and ground water during 1984 was about $\$ 50$ million. The distribution of these costs for the various purpose categories is shown in figure $8 B$. Based on these estimates, 72 percent of total laboratory costs were for permit requirements, 2 percent for compliance-and-enforcement activities, and 26 percent for characterizing ambient conditions.

For Ohio, estimated laboratory expenditures by organizational category, for both surface and ground water, are summarized in table 4. Excluding permitrequired samples, estimated costs were greatest by far for local agencies for both surface- and ground-water samples, reflecting the large number of samples collected by local agencies for monitoring drinking-water supplies. Estimated costs for surface and ground water were similar for local agencies; however, for Federal, State, and regional agencies and academic institutions, estimated costs were 
Table 3. Summary of estimated laboratory costs by organizational category, Colorado, 1984 $[<$, less than]

\begin{tabular}{|c|c|c|c|}
\hline \multirow[b]{2}{*}{ Organizational category ${ }^{1}$} & \multicolumn{3}{|c|}{$\begin{array}{l}\text { Estimated }{ }^{2} \text { cost in thousands of dollars } \\
\text { and percentages }{ }^{3} \text { (in parenthesis) }\end{array}$} \\
\hline & Total & $\begin{array}{l}\text { Surface } \\
\text { water }\end{array}$ & $\begin{array}{l}\text { Ground } \\
\text { water }\end{array}$ \\
\hline Federal & $\begin{array}{r}2,182 \\
(16)\end{array}$ & $\begin{array}{l}912 \\
(8)\end{array}$ & $\begin{array}{r}1,270 \\
(53)\end{array}$ \\
\hline State & $\begin{array}{r}2,794 \\
(21)\end{array}$ & $\begin{array}{r}2,771 \\
(25)\end{array}$ & $\begin{array}{r}23 \\
(1)\end{array}$ \\
\hline Regional & $\begin{array}{l}495 \\
(4)\end{array}$ & $\begin{array}{l}495 \\
(5)\end{array}$ & $\begin{aligned} 0 \\
(0)\end{aligned}$ \\
\hline Local & $\begin{array}{r}1,828 \\
(13)\end{array}$ & $\begin{array}{r}1,670 \\
(15)\end{array}$ & $\begin{array}{l}158 \\
(7)\end{array}$ \\
\hline Academic & $\begin{array}{l}107 \\
(1)\end{array}$ & $\begin{array}{l}101 \\
(1)\end{array}$ & $\begin{array}{r}6 \\
(<1)\end{array}$ \\
\hline Subtotals, all organizations ${ }^{1}$. & $\begin{array}{r}7,406 \\
(55)\end{array}$ & $\begin{array}{r}5,949 \\
(54)\end{array}$ & $\begin{array}{r}1,457 \\
(61)\end{array}$ \\
\hline Subtotals, permit-required ${ }^{4}$. & $\begin{array}{r}6,078 \\
(45)\end{array}$ & $\begin{array}{r}5,159 \\
(46)\end{array}$ & $\begin{array}{r}919 \\
(39)\end{array}$ \\
\hline Totals $^{3}$ (rounded) & 13,490 & 11,110 & 2,380 \\
\hline \multicolumn{4}{|c|}{$\begin{array}{l}{ }^{1} \text { Cost and percentage breakdown by organizational category is for } \\
\text { les collected for compliance-and-enforcement activities and for ambient- } \\
\text { itions purposes. }\end{array}$} \\
\hline \multicolumn{4}{|c|}{$\begin{array}{l}\text { 2Estimates based on } 1984 \text { U.S. Geological Survey laboratory costs. } \\
\text { 3Percentages of totals shown below in same column. }\end{array}$} \\
\hline $\begin{array}{l}{ }^{4} \text { Information is inadequate to } \\
\text { costs among organizational categor } \\
\text { agencies and private organizations }\end{array}$ & $\begin{array}{l}\text { strib } \\
\text { : how }\end{array}$ & $\begin{array}{l}\text { nit-requ } \\
\text { ost are }\end{array}$ & $\begin{array}{l}\text { boratory } \\
\text { d by local }\end{array}$ \\
\hline
\end{tabular}

much higher for surface water, reflecting the larger proportion of surface-water samples collected by the agencies.

Estimated laboratory costs for compliance-andenforcement activities and characterizing ambient conditions (permit-required samples excluded) for each major property and constituent group during 1984 are summarized in figure $9 B$. For surface water in Ohio, the greatest costs, 34 percent, were for analyses of priority pollutants, although this group represents only 5 percent of the total surface-water samples. This results from the large cost (more than $\$ 400$ per sample) of priority-pollutants analyses. Similarly, 63 percent of the estimated total laboratory costs in Ohio for ground-water samples were for the priority-pollutants group, although this group represents only 15 percent of the total ground-water samples. In contrast, biota (mainly bacteriological) determinations, representing 24 percent of the ground-water samples, accounted for only 5 percent of the estimated ground-water costs because of the low unit costs for bacteriological determinations. 

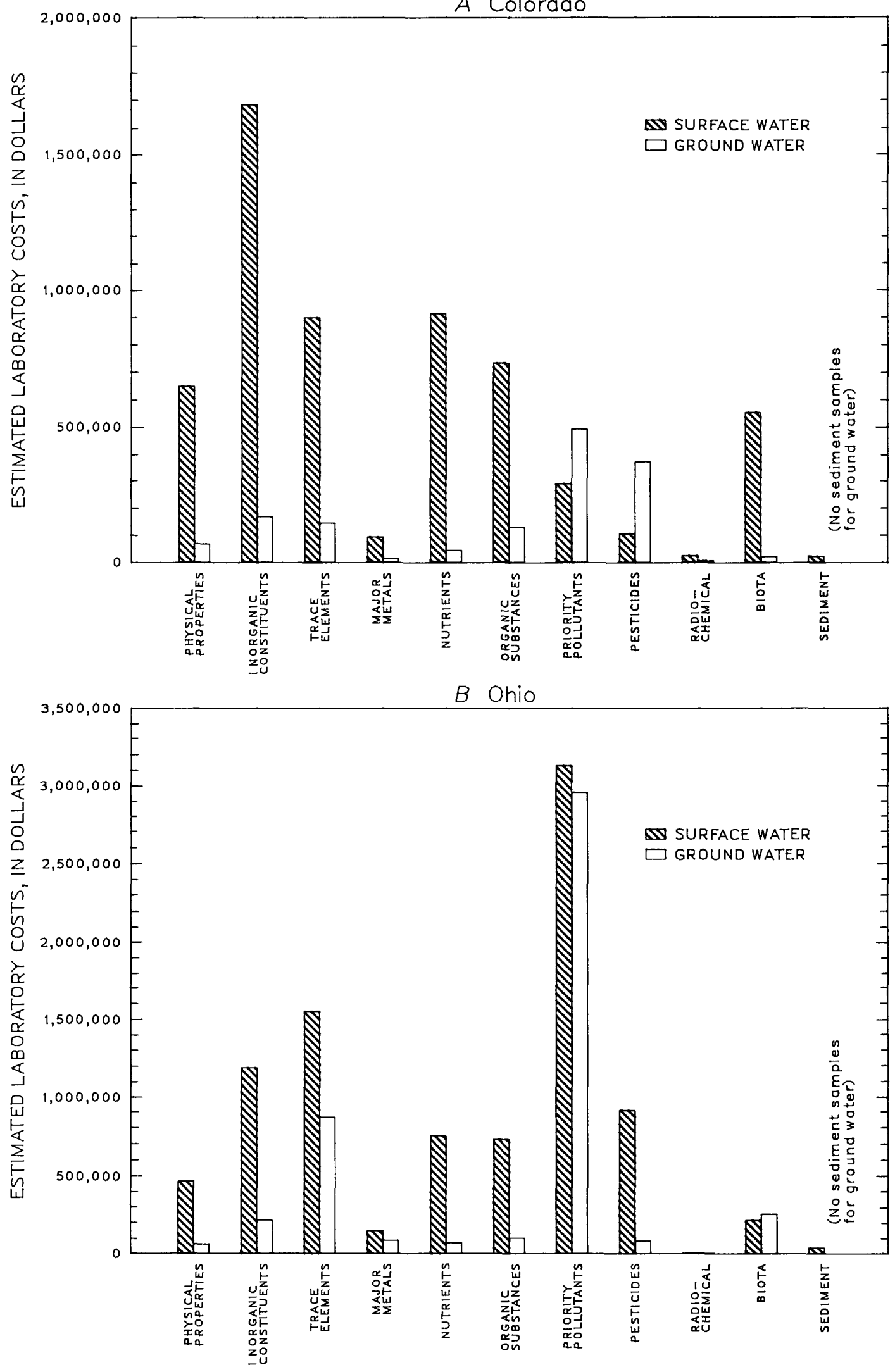

Figure 9. Estimated costs for laboratory analysis of surface- and ground-water samples, by property and constituent group, 1984: (A), Colorado and (B), Ohio (note the different vertical scales). Samples reported to meet permit requirements are not included. Estimates are based on 1984 U.S. Geological Survey laboratory costs (table 9). (See also table 6.) 


\section{Comparison between States}

Total estimated laboratory costs of all samples reported for Colorado and Ohio during 1984 were $\$ 63$ million. Estimated expenditures were higher in Ohio than in Colorado because more samples were reported for Ohio. Samples collected to meet permit requirements represented the largest percentage of the total estimated laboratory costs in each State-45 percent in Colorado and 72 percent in Ohio. In Colorado, State agencies had the largest estimated laboratory expenditures; whereas, in Ohio, the largest estimated laboratory expenditures were by local agencies.

In terms of the estimated costs of analyzing the samples in each of the property or constituent groups for both surface- and ground-water samples (fig. 9), the largest laboratory costs in Colorado were for the analysis of inorganic constituents; the trace-elements group accounted for the second highest expenditure. In Ohio, the largest estimated costs were for priority-pollutants analyses; the second-largest estimated costs were for trace elements. Although 34 percent more trace-element samples were reported than priority-pollutant samples (in Ohio, permit-required samples excluded), the estimated laboratory costs of priority pollutants were more than twice those of the trace-element samples because of the larger unit cost of the latter analyses.

The laboratory costs are only part, though a major part, of the total costs of water-quality data-collection programs. Other costs, such as for sample collection, equipment costs, and program administration, vary greatly from agency to agency and could not be reliably estimated during this study. For many agencies, however, total program costs are believed to be more than twice the laboratory costs.

As previously stated, to gain a better insight of the relation between laboratory costs and total program costs, water-quality programs of the U.S. Geological Survey in the two States were examined. In Colorado, 22 U.S. Geological Survey programs reported total costs of about $\$ 1.5$ million in 1984. Estimated laboratory costs for these programs were $\$ 527,800$, or 35 percent of total program costs. In Ohio, 13 U.S. Geological Survey programs reported total costs of about $\$ 1$ million. Estimated laboratory costs were $\$ 177,500$, or 18 percent of total program costs. For this agency's programs, as with those of other reporting agencies, laboratory costs varied from program to program depending on the numbers of samples and the types of analyses performed.

\section{EVALUATION OF WATER-QUALITY DATA}

The major objective of this study is to determine if data collected by different agencies for various purposes, using different methods, can be aggregated into a consistent data base for use in addressing water-quality issues of regional and national scope. The screening process discussed in this section was designed to identify data that will provide a common basis for further evaluation. This screening procedure does not imply that data not meeting the screening criteria are not useful, or that they do not meet their intended needs or fulfill mandated requirements of the agencies collecting the data-only that their characteristics are not consistent with those chosen as the standard for this study.

The screening process is described in detail in the section on Methods of Acquiring, Compiling, and Evaluating Information, and is summarized here by the following diagram:

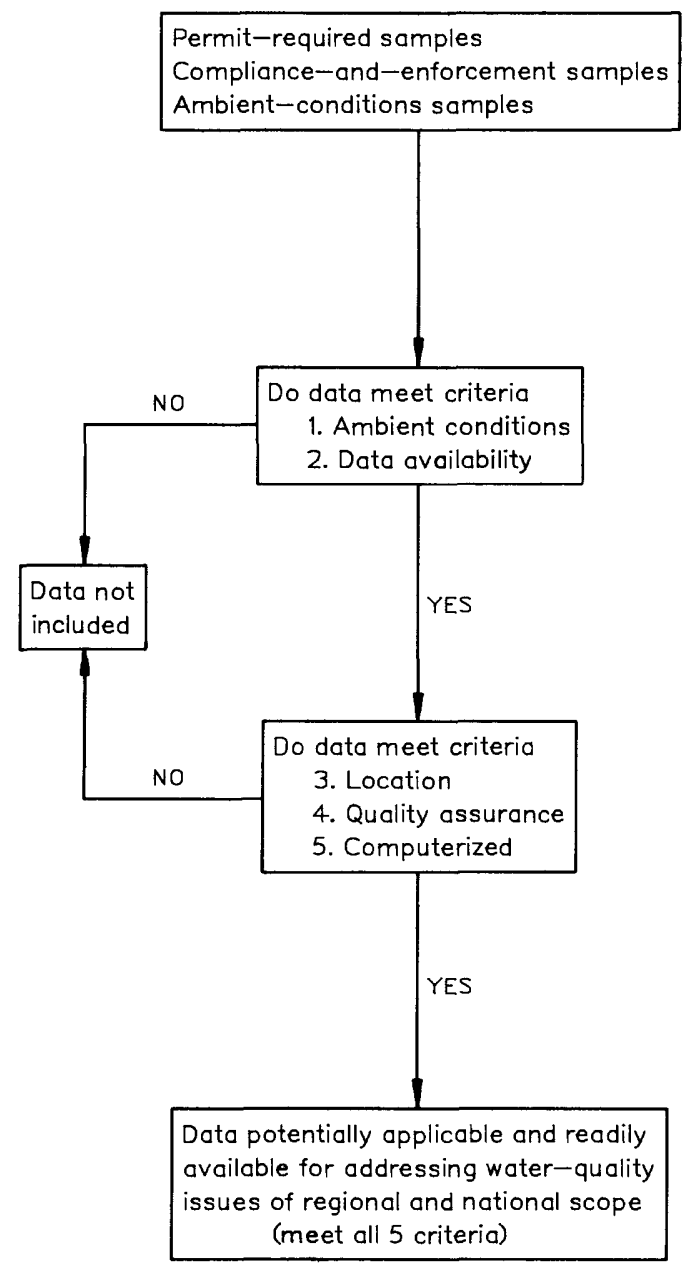

The original data base contained all samples, reported by all organizations, for all purposes, in all property or constituent groups. Those samples meeting criteria 1 and 2 were identified first and, of these samples, those meeting criteria 3, 4, and 5 were then identified. Detailed results of the screening process are presented in the Supplemental Data section (tables 10-21). 
Table 4. Summary of estimated laboratory costs by organizational category, Ohio, 1984 $[<$, less than]

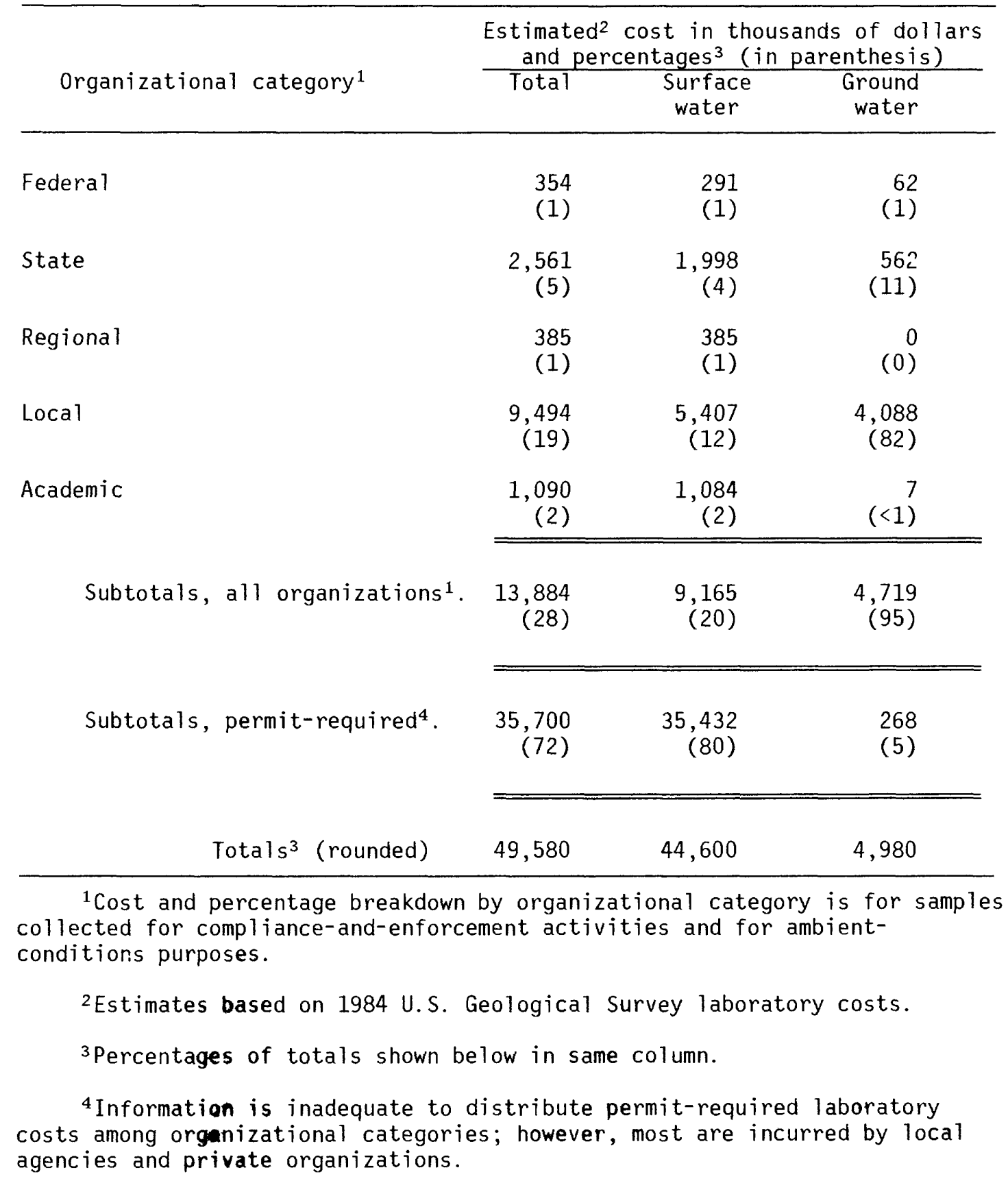

\section{Colorado}

\section{Surface Water}

The numbers of surface-water samples reported for Colorado during 1984 that met the screening criteria, and their estimated laboratory costs, are summarized in figure $10 A$ and $B$. About 34 percent of the total reported samples met all five screening criteria and this also represented 34 percent of the estimated laboratory costs. Fifty-one percent of the samples were not representative of ambient stream conditions, while only 2 percent of the samples were not publicly available. An additional 13 percent of the samples either did not have adequate sitelocation information, were not quality assured, or were not computerized. After screening, a surface-water data base of about 105,000 samples remained potentially applicable to and readily available for addressing waterquality issues of regional and national scope. 


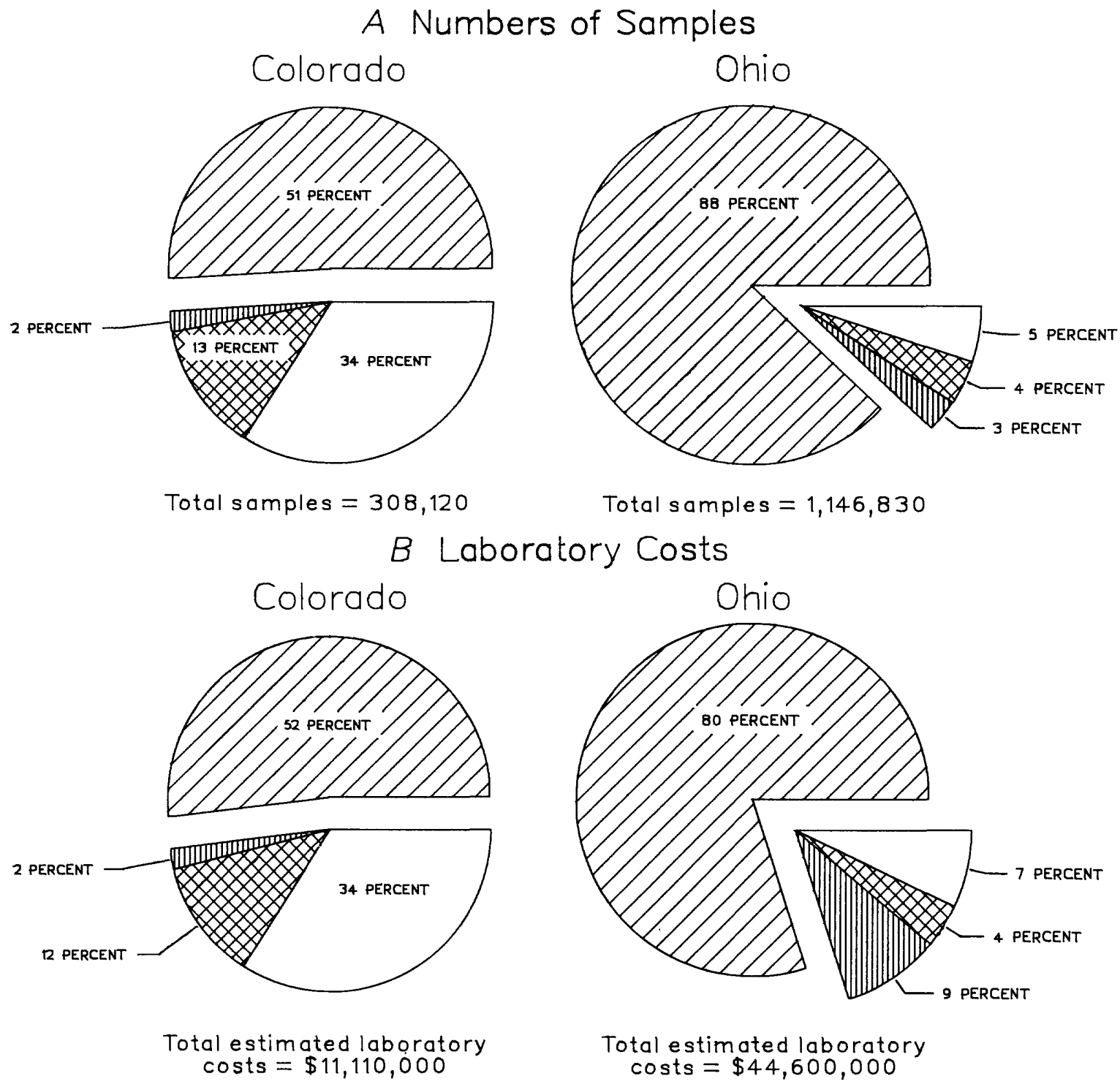

\section{EXPLANATION}

7 SAMPLES REPORTED TO MEET PERMIT REQUIREMENTS AND OTHER NON - AMBIENT SAMPLES; DID NOT MEET CRITERION 1

[I] [I] SAMPLE INFORMATION NOT PUBLICLY AVAILABLE; DID NOT MEET CRITERION 2

¿ SAMPLES NOT HAVING LOCATION INFORMATION, NOT QUALITY ASSURED, OR NOT COMPUTERIZED; DID NOT MEET CRITERION 3,4, OR 5

SAMPLES MEETING ALL 5 CRITERIA

Figure 10. Summary of screening results for surface-water samples, Colorado and Ohio, 1984: (A), numbers of samples and $(B)$, their estimated laboratory costs. See text section on Screening Criteria for explanation of method.

Screening results for Colorado surface-water data for each of the organizational categories are summarized in figure $11 A$. (Permit-required samples are not included in these diagrams.) About 64 percent of all reported surfacewater samples met all five criteria when permit-required samples were excluded. About 80 percent or more of the data collected by Federal, State, and regional agencies met all criteria. However, only 8 percent of the data collected by local agencies met all the screening criteria.

After excluding the permit-required samples, most of the remaining surface-water samples for Colorado were representative of ambient conditions and were publicly available. For the remaining three criteria (adequate sitelocation information, quality assurance, and computerized 
A Colorado

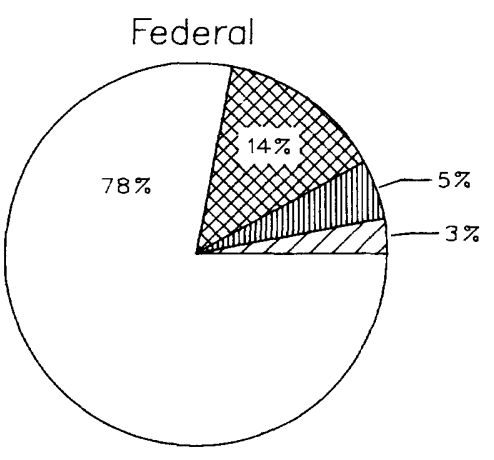

Samples $=30,420$

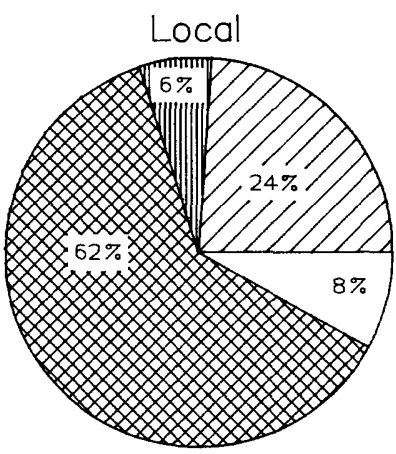

Somples $=41,780$

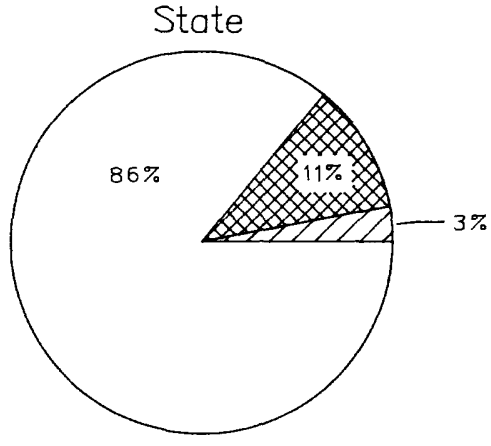

Samples $=73,080$

Academic

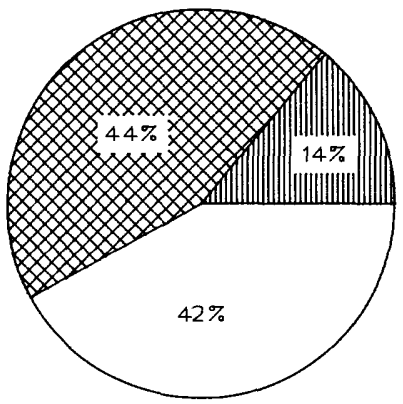

Samples $=2730$

$B$ Ohio

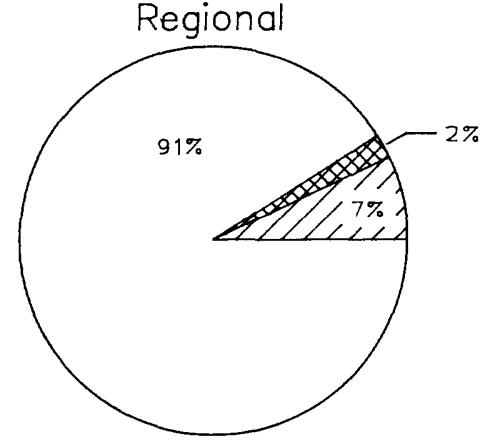

Samples $=16,490$

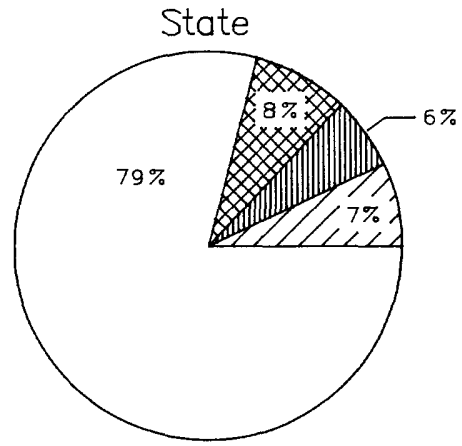

Samples $=37,650$

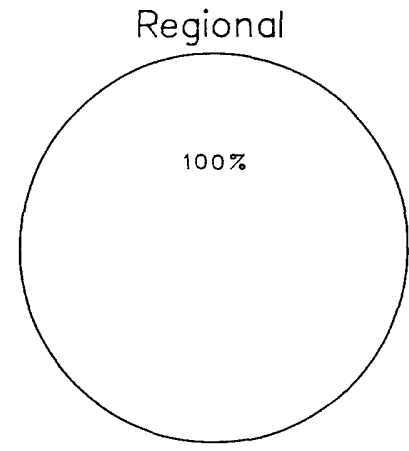

Samples $=4000$

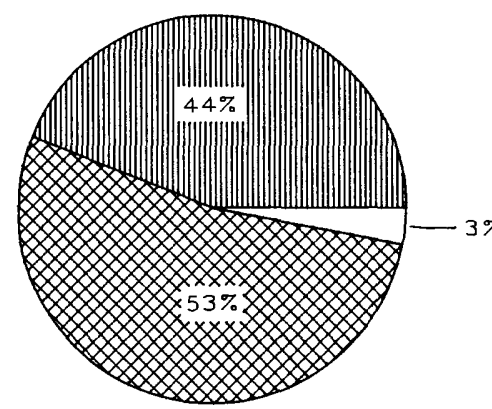

Samples $=78,590$
Academic

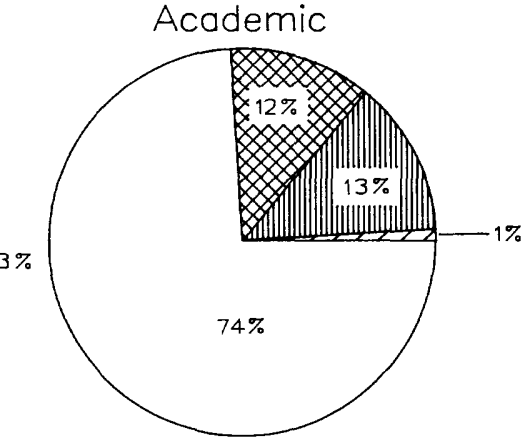

Samples $=12,930$

Figure 11. Summary of screening results for surface-water samples for Federal, State, regional, and local agencies and academic institutions, 1984: $(A)$, Colorado and $(B)$, Ohio. Permit-required samples are not included; see the text section on Screening Criteria for explanation of method; see also tables 10 and 12 (Colorado) and tables 16 and 18 (Ohio). 
data), the percentages of reported samples not meeting these criteria ranged from as much as 62 percent for local agencies to as little as 2 percent for regional agencies. Adequate location information and a quality-assurance program were reported for most samples. The lack of computerized data files was the most limiting of these three criteria for all organizational categories.

\section{Ground Water}

The screening results for the Colorado ground-water samples are summarized in figure $12 A$ and $B$. Twentyseven percent of the total number of reported samples met all five criteria and represented 13 percent of the estimated laboratory costs. About $\mathbf{4 8}$ percent were not representative

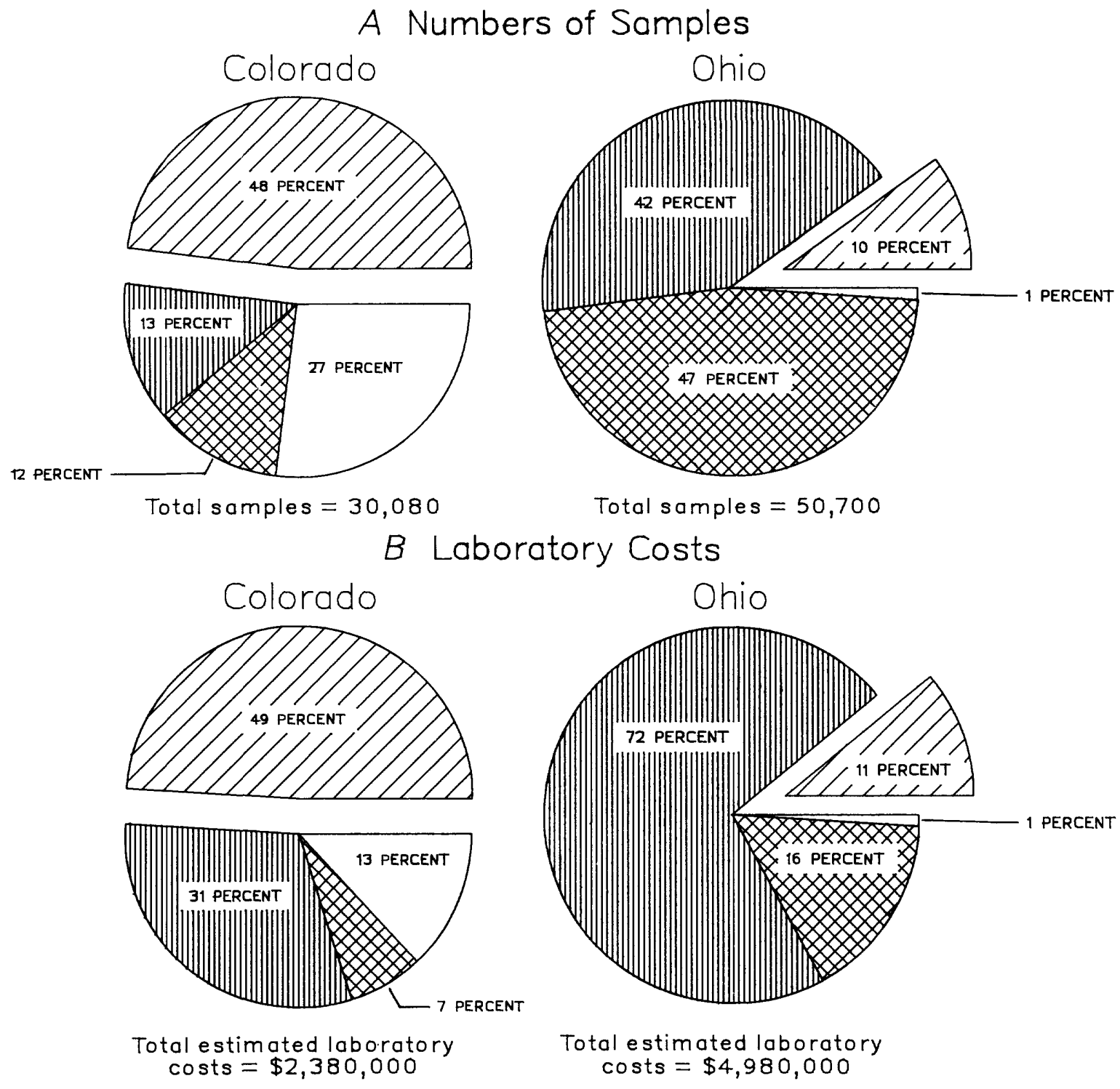

EXPLANATION

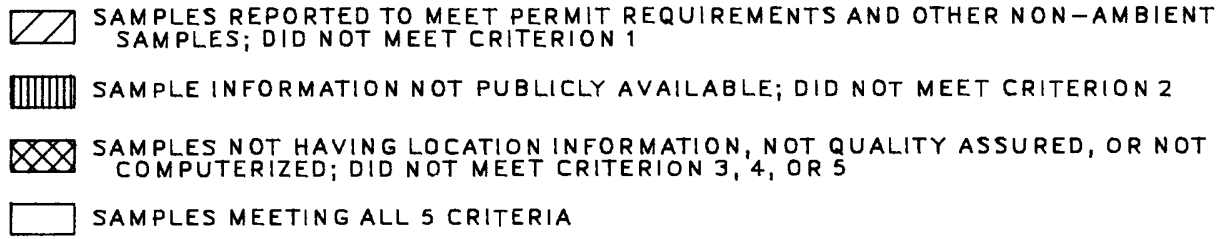

Figure 12. Summary of screening results for ground-water samples, Colorado and Ohio, 1984: (A), numbers of samples and $(B)$, their estimated laboratory costs. See text section on Screening Criteria for explanation of methods. 


\section{A Colorado}

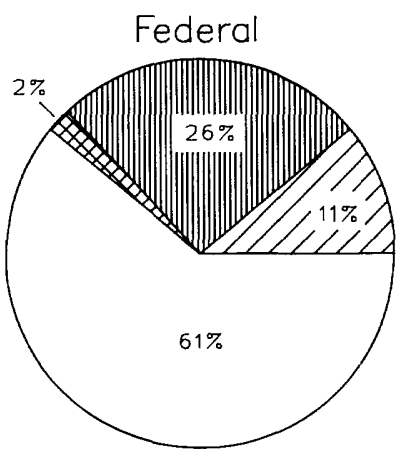

Samples $=13,820$

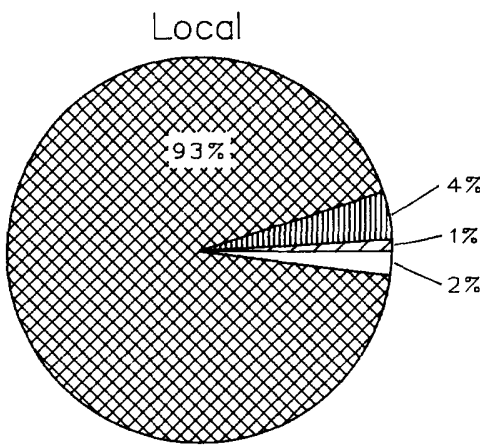

Samples $=3500$

Federal

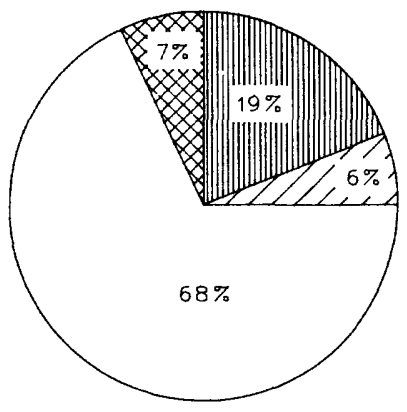

Samples $=990$

Local

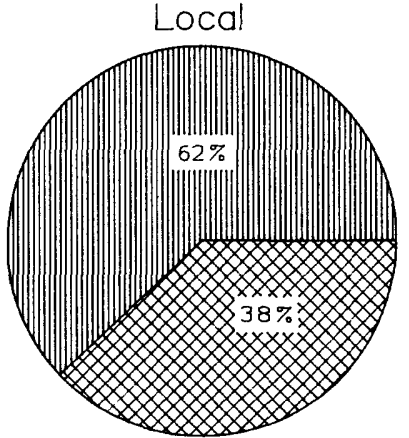

Somples $=33,830$

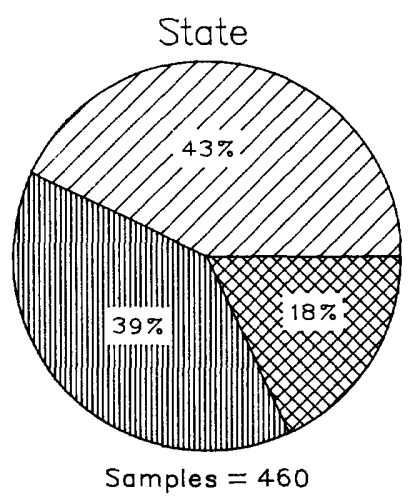

Academic

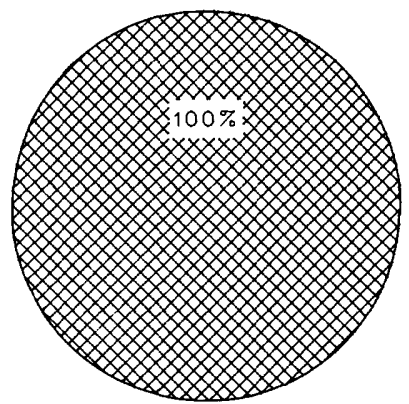

Samples $=190$

$B$ Ohio

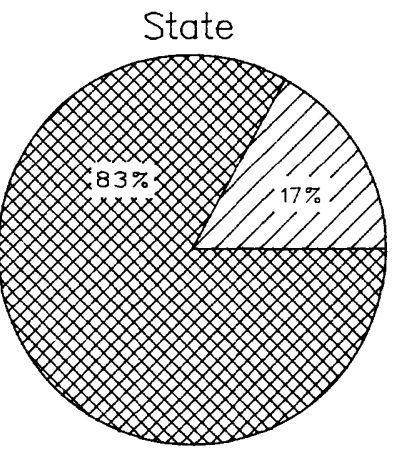

Somples $=13,060$

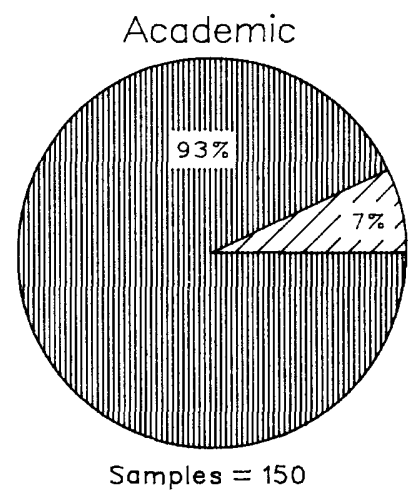

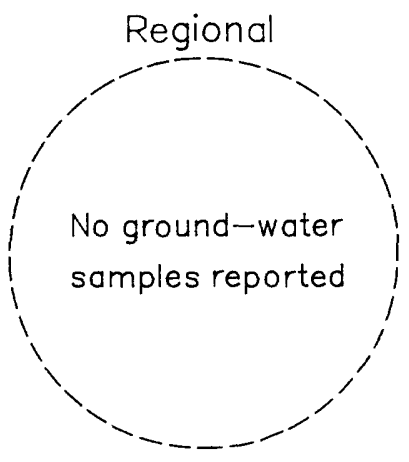

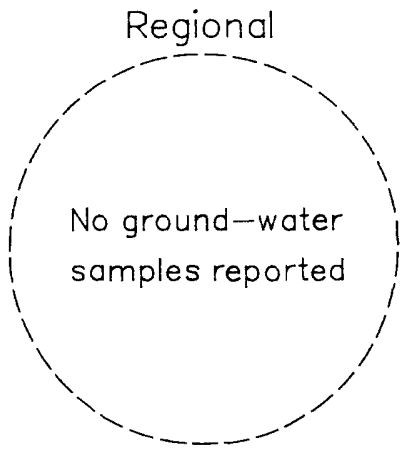

EXPLANATION

77 SAMPLES NOT REFLECTING AMBIENT CONDITIONS; DID NOT MEET CRITERION SAMPLE INFORMATION NOT PUBLICLY
AVAILABLE; DIONOT MEET CRITERION 2

SAMPLES NOT HAVING LOCATION INFORMATION NOT QUALITY ASSURED, OR NOT COMPUTERIZED; DID NOT MEET CRITERION 3, 4, OR 5

SAMPLES MEETING ALL 5 CRITERIA

Figure 13. Summary of screening results for ground-water samples for Federal, State, regional, and local agencies and academic institutions, 1984: $(A)$, Colorado and $(B)$, Ohio. Permit-required samples are not included; see the text section on Screening Criteria for explanation of methods; see also tables 11 and 13 (Colorado) and tables 17 and 19 (Ohio). 
of ambient conditions; these accounted for 49 percent of the costs. Thirteen percent of the samples were not available to the public, primarily due to legal constraints on the data's availability. Twelve percent of the samples, which represented 7 percent of the estimated laboratory costs, either did not have adequate site-location information, were not quality assured, or were not computerized. A data base of about 8,400 ground-water samples remained after screening.

The screening results for Colorado ground-water data are summarized in figure $13 A$ for the different organizational categories. (Permit-required samples are not included in these figures.) About 47 percent of all reported ground-water samples met all five criteria. Federal agencies' programs that accounted for 77 percent of the non-permit-required ground-water samples also had the largest percentage ( 61 percent) of samples meeting all five criteria. The only other ground-water samples meeting all five criteria were collected by local agencies.

State and local agencies and academic institutions reported a relatively small percentage ( 23 percent) of the ground-water samples in Colorado. Most of the groundwater samples collected by State agencies were for compliance-and-enforcement activities; as a result, they were not representative of ambient conditions and not publicly available. Like the surface-water samples, the single most limiting criterion affecting the ground-water samples reported by local agencies was the lack of data in computer files.

For all reported samples in Colorado during 1984 (including permit-required samples), criterion 1 (ambient conditions) had the greatest overall effect on the percentage of samples passing the screening process. Fifty-one percent of all samples, both surface- and ground-water, did not meet this criterion (tables 10 and 11, Supplemental Data section). Of the other criteria, criterion 5 (computerized data) is the most limiting. Twenty-five percent of the samples meeting the ambient-conditions and dataavailability criteria do not meet the computerized-data criterion (tables 10,11,12, and 13). However, the percentage of samples that meet all criteria except criterion 5 is less than 3 percent, indicating that a large number of the programs reported samples that failed to meet two or more of the criteria. Computerizing the data that met all the criteria except 5 would result in only an 8-percent increase in the Colorado data that pass the screening and, by these criteria, are judged potentially applicable to and readily available for addressing water-quality issues of regional and national scope.

\section{Ohio}

\section{Surface water}

The screening results for Ohio surface-water samples and their associated estimated laboratory costs are summarized in figure $10 A$ and $B$. Only 5 percent of the total number of samples (7 percent of estimated costs) met all five criteria. This represents a surface-water data base of about 56,000 samples (table 18) potentially available for addressing water-quality issues of regional and national scope. Eighty-eight percent of the samples were not representative of ambient conditions; most of these were permit-required samples. Three percent of the samples were not publicly available, and 4 percent either did not have adequate site-location information, were not quality assured, or were not computerized.

Screening results for Ohio surface-water samples are summarized by organizational category in figure $11 B$. (Permit-required samples are not included.) Without the permit-required samples, about 82 percent of the surfacewater samples reported by Federal, State, and regional agencies, and academic institutions met all criteria (tables 16 and 18). Only 3 percent of the samples reported by local agencies met all criteria; the major limitation to using these data was the small percentage of data in computer files and limited availability of the data for public use.

\section{Ground water}

The screening results for Ohio ground-water samples, and their associated estimated costs, are summarized in figure $12 A$ and $B$. Only one percent of the samples (1 percent of estimated costs) met all five criteria. This represents 670 ground-water samples (table 19) potentially available for addressing questions of regional and national scope. Ten percent of the samples (11 percent of estimated costs) were not representative of ambient conditions. Forty-two percent of the samples were not publicly available because of the large number of ground-water samples reported by local agencies that do not make their data available to the public. Forty-seven percent either did not have adequate site-location information, were not quality assured, or were not computerized. The major limitation was the lack of data in computer files.

The screening results for Ohio ground-water samples by organizational category are summarized in figure 13 B . (Permit-required samples are not included.) Sixty-eight percent of samples reported by Federal agencies, and only samples reported by Federal agencies, met all five criteria (tables 17 and 19). The major limitation for Federal-agency samples was lack of data availability. Some Federal agencies were collecting ground-water data that were unavailable at the time of this study, pending review and publication. Limitations on including samples reported by the other organizational groups varied. Samples reported by State agencies were affected by the data not being computerized and the lack of site-location information. Ground-water samples reported by local agencies had the same limitations as the surface-water samples 
Table 5. Numbers and percentages of samples and estimated laboratory costs (surface water and ground water combined) before and after screening, by source of data, Colorado and Ohio, 1984

[Cost estimates are based on 1984 U.S. Geological Survey laboratory costs; --, not applicable]

\begin{tabular}{|c|c|c|c|c|c|c|c|c|c|c|c|c|}
\hline \multirow[b]{3}{*}{ Organizational category } & \multicolumn{6}{|c|}{ Colorado } & \multicolumn{6}{|c|}{ Ohio } \\
\hline & \multicolumn{2}{|c|}{ Before screening } & \multicolumn{2}{|c|}{ After screening } & \multicolumn{2}{|c|}{ Remaining } & \multicolumn{2}{|c|}{ Before screening } & \multicolumn{2}{|c|}{ After screening } & \multicolumn{2}{|c|}{ Remaining } \\
\hline & $\begin{array}{l}\text { Number of } \\
\text { samples }\end{array}$ & $\begin{array}{l}\text { Estimated } \\
\text { cost } \\
\text { (thousands } \\
\text { of dollars) }\end{array}$ & $\begin{array}{l}\text { Number of } \\
\text { samples }\end{array}$ & $\begin{array}{l}\text { Estimated } \\
\text { cost } \\
\text { (thousands } \\
\text { of dollars) }\end{array}$ & $\begin{array}{l}\text { Number of } \\
\text { samples } \\
\text { (percent) }\end{array}$ & $\begin{array}{c}\text { Estimated } \\
\text { cost } \\
\text { (percent) }\end{array}$ & $\begin{array}{l}\text { Number of } \\
\text { samples }\end{array}$ & $\begin{array}{c}\text { Estimated } \\
\text { cost } \\
\text { (thousands } \\
\text { of dollars) }\end{array}$ & $\begin{array}{l}\text { Number of } \\
\text { samples }\end{array}$ & $\begin{array}{l}\text { Estimated } \\
\text { cost } \\
\text { (thousands } \\
\text { of dollars) }\end{array}$ & $\begin{array}{l}\text { Number of } \\
\text { samples } \\
\text { (percent) }\end{array}$ & $\begin{array}{c}\text { Estimated } \\
\text { cost } \\
\text { (percent) }\end{array}$ \\
\hline \multicolumn{13}{|l|}{ Federal: } \\
\hline $\begin{array}{l}\text { U.S. Geological } \\
\text { Survey. }\end{array}$ & 19,960 & 530 & 18,910 & 475 & 95 & 90 & 8,410 & 178 & 8,410 & 178 & 100 & 100 \\
\hline $\begin{array}{l}\text { 0ther Department of the } \\
\text { Interior agencies. }\end{array}$ & 11,490 & 368 & 10,170 & 332 & 89 & 90 & 120 & 3 & 60 & 1 & 50 & 38 \\
\hline $\begin{array}{l}\text { U.S. Environmental } \\
\text { Protection Agency. }\end{array}$ & 2,360 & 320 & 0 & 0 & 0 & 0 & 240 & 11 & 0 & 0 & 0 & 0 \\
\hline Other Federal agencies. & 10,430 & 964 & 3,010 & 149 & 29 & 15 & 3,580 & 162 & 3,270 & 144 & 91 & 89 \\
\hline $\begin{array}{l}\text { Total, Federal } \\
\text { agencies. }\end{array}$ & 44,240 & 2,182 & 32,090 & 956 & 72 & 44 & 12,350 & 354 & 11,740 & 323 & 95 & 91 \\
\hline State agencies. & 73,540 & 2,794 & 62,610 & 2,452 & 85 & 88 & 50,710 & 2,561 & 29,530 & 1,417 & 58 & 55 \\
\hline \multicolumn{13}{|l|}{ Regional: } \\
\hline Intrastate agencies. & 16,490 & 495 & 15,010 & 436 & 91 & 88 & -- & -- & -- & -- & -- & -- \\
\hline Interstate agencies. & -- & -- & -- & -- & -- & -- & 4,000 & 385 & 4,000 & 385 & 100 & 100 \\
\hline $\begin{array}{l}\text { Total, regional } \\
\text { agencies. }\end{array}$ & 16,490 & 495 & 15,010 & 436 & 91 & 88 & 4,000 & 385 & 4,000 & 385 & 100 & 100 \\
\hline Local agencies. & 45,280 & 1,828 & 3,450 & 217 & 8 & 12 & 112,420 & 9,494 & 2,080 & 83 & 2 & 1 \\
\hline Academic institutions. & 2,920 & 107 & 1,140 & 56 & 39 & 52 & 13,080 & 1,090 & 9,600 & 817 & 73 & 75 \\
\hline $\begin{array}{l}\text { Subtotals, all } \\
\text { organizations. }\end{array}$ & 182,470 & 7,406 & 114,300 & 4,117 & 63 & 56 & 192,560 & 13,884 & 56,950 & 3,025 & 30 & 22 \\
\hline $\begin{array}{l}\text { Subtotals, } \\
\text { permit-required. }\end{array}$ & 155,730 & 6,078 & 0 & 0 & 0 & 0 & $1,004,970$ & 35,700 & 0 & 0 & 0 & 0 \\
\hline Totals (rounded) & 338,200 & 13,490 & 114,300 & 4,120 & 34 & 31 & $1,197,530$ & 49,580 & 56,950 & 3,020 & 5 & 6 \\
\hline
\end{tabular}

reported by these groups; namely, lack of data available to the public and data not being computerized. Most (93 percent) of the ground-water samples reported by academic institutions were not available to the public. Regional agencies did not report any ground-water samples.

Overall in Ohio, the abundance of data reflecting nonambient conditions (including permit-required data) was the greatest limitation to use of both the surface- and ground-water samples for assessing general water-quality conditions. The second was the lack of data in computerized files. Four percent of all surface-water samples and 47 percent of all ground-water samples met all the criteria except number 5 (computerized data). If these data were put into computer files, the number of samples meeting all the criteria would increase by about 70,000 , which would more than double the data base of almost 57,000 samples that passed the screening.

\section{Comparison Between States}

Although more samples were reported for Ohio than for Colorado, fewer of the Ohio samples met all criteria; thus, fewer Ohio data are potentially applicable to and readily available for addressing water-quality issues of regional and national scope. The total number of samples and their estimated laboratory costs, before and after the screening, are summarized for both States in table 5. For Colorado, 34 percent of all reported samples met all five screening criteria ( 31 percent of the estimated costs). In contrast, for Ohio, only 5 percent of the samples ( 6 percent of the estimated costs) remained after the screening. Regional agencies in both States had the largest percentage of samples remaining after the screening-91 percent in Colorado and 100 percent in Ohio. In both States, local agencies had the smallest number of samples meeting all criteria, the noncomputerized data being one of the most 
Table 6. Numbers and percentages of samples and estimated laboratory costs (surface water and ground water combined) before and after screening, by property and constituent groups, Colorado and Ohio, 1984

[Cost estimates are based on 1984 U.S. Geological Survey laboratory costs]

\begin{tabular}{|c|c|c|c|c|c|c|c|c|c|c|}
\hline \multirow{3}{*}{$\begin{array}{c}\text { Property or } \\
\text { constituent group }\end{array}$} & \multicolumn{5}{|c|}{ Colorado } & \multicolumn{5}{|c|}{ Ohio } \\
\hline & \multicolumn{2}{|c|}{ Before screening } & \multicolumn{2}{|c|}{ After screening } & \multirow{2}{*}{$\begin{array}{l}\text { Percentage } \\
\text { of samples } \\
\text { (also costs) } \\
\text { remaining }\end{array}$} & \multicolumn{2}{|c|}{ Before screening } & \multicolumn{2}{|c|}{ After screening } & \multirow{2}{*}{$\begin{array}{l}\text { Percentage } \\
\text { of samples } \\
\text { (also costs) } \\
\text { remaining }\end{array}$} \\
\hline & $\begin{array}{l}\text { Number of } \\
\text { samples }\end{array}$ & $\begin{array}{l}\text { Estimated } \\
\text { cost } \\
\text { (thousands } \\
\text { of dollars) }\end{array}$ & $\begin{array}{l}\text { Number of } \\
\text { samples }\end{array}$ & $\begin{array}{l}\text { Estimated } \\
\text { cost } \\
\text { (thousands } \\
\text { of dollars) }\end{array}$ & & $\begin{array}{c}\text { Number of } \\
\text { samples }\end{array}$ & $\begin{array}{l}\text { Estimated } \\
\text { cost } \\
\text { (thousands } \\
\text { of dollars) }\end{array}$ & $\begin{array}{l}\text { Number of } \\
\text { samples }\end{array}$ & $\begin{array}{l}\text { Estimated } \\
\text { cost } \\
\text { (thousands } \\
\text { of dollars) }\end{array}$ & \\
\hline Physical properties & 119,310 & 1,617 & 38,710 & 524 & 32 & 511,900 & 6,936 & 12,370 & 168 & 2 \\
\hline Inorganic constituents & 62,270 & 2,943 & 28,660 & 1,354 & 46 & 370,220 & 17,493 & 7,990 & 378 & 2 \\
\hline Trace elements & 13,940 & 1,326 & 7,310 & 695 & 52 & 91,210 & 11,154 & 5,040 & 616 & 6 \\
\hline Major metals & 13,810 & 127 & 5,700 & 52 & 41 & 31,910 & 294 & 3,700 & 34 & 12 \\
\hline Nutrients & 28,110 & 1,221 & 14,540 & 633 & 52 & 69,990 & 3,041 & 8,820 & 383 & 13 \\
\hline Organic substances & 35,870 & 2,638 & 6,570 & 483 & 18 & 23,550 & 1,732 & 4,160 & 306 & 18 \\
\hline Priority pollutants & 4,410 & 1,810 & 244 & 101 & 6 & 15,160 & 6,232 & 1,100 & 452 & 7 \\
\hline Pesticides & 1,870 & 564 & 90 & 30 & 5 & 3,410 & 1,029 & 1,800 & 543 & 53 \\
\hline Radiochemicals & 1,200 & 32 & 260 & 6 & 22 & 650 & 17 & 50 & 1 & 8 \\
\hline Biota & 52,460 & 1,180 & 9,960 & 224 & 19 & 71,730 & 1,614 & 4,820 & 109 & 7 \\
\hline Sediment & 4,940 & 25 & 2,120 & 10 & 43 & 7,800 & 38 & 7,100 & 36 & 91 \\
\hline Total (rounded) & 338,000 & 13,490 & 114,000 & 4,120 & & $1,198,000$ & 49,580 & 57,000 & 3,020 & \\
\hline
\end{tabular}

limiting criteria. Excluding the permit-required samples, this criterion was the largest limitation for all data reported in both States.

For each major property and constituent group, the total number of samples and their estimated costs before and after the screening are summarized in table 6. For Colorado, more than 50 percent of trace-element and nutrient samples passed the screening step. For Ohio, the group with the largest number of samples meeting all criteria was physical properties; however, this represented only 2 percent of the total number of physical properties samples before screening. The inorganic constituents and nutrients groups also had large numbers of samples remaining for Ohio, but represented relatively small percentages of the number of samples in these groups before screening.

Excluding permit-required samples, the lack of data in computer files was the biggest limitation in both States on the applicability of the data for addressing waterquality issues of regional and national scope. For Colorado, if all data were computerized, the number of samples passing the screening step would have increased by only 8 percent; however, for Ohio, if all data were computerized, the number of samples would increase by 123 percent. The large difference in the effect of this criterion between the States is mainly due to the large number of samples collected in Colorado by Federal agencies, which have computerized data, and the large number of samples collected in Ohio by local agencies, which do not have computerized data files.

The 1984 data base meeting all criteria and, therefore, potentially applicable to and readily available for the evaluation of broad-scope water-quality issues, consists of 114,300 samples in Colorado and 57,000 samples in Ohio. These totals represent both surface and ground water and all property and constituent groups. These totals also represent 34 percent of all samples available before the screening in Colorado and 5 percent of all samples available before the screening in Ohio. When permit-required samples are excluded, however, the percentages of samples meeting all criteria increases to 63 percent (of nonpermit samples) in Colorado and 30 percent in Ohio.

The larger decrease in samples for Ohio after screening is the result of the greater proportion of samples collected in that State to meet permit requirements. In Colorado, the majority of samples before and after the screening were collected by State agencies. In Ohio, State agencies had the largest number of samples remaining after screening, but regional agencies had the largest percentage (100 percent) of samples remaining.

It should be emphasized that even this data base is not necessarily all applicable to the aforementioned regional and national issues. In Phase II of this study, a detailed evaluation of the programs' sample-collection techniques, quality-assurance procedures, and laboratoryanalytical methods will be undertaken, and the numbers of applicable data may be reduced further as a result of that step. Therefore, the numbers of post-screening samples given herein, including the increases potentially available by computerizing appropriate data files, should be considered as the maximum for the two States in 1984 .

\section{REFERENCES}

Blodgett, J.E., 1983, Summary of hearings of "National Environmental Monitoring": Washington, D.C., Congressional Research Service, 20 p.

Cable, L.W., 1982, The Federal water data coordination program 1964-1980: U.S. Geological Survey Office of Water Data Coordination, $47 \mathrm{p}$.

Feltz, H.R., Anthony, E.R., and Sadler, Pamela, eds., 1983, Water-quality laboratory services catalog: U.S. Geological Survey Open-File Report 83-758, 130 p. 
Solley, W.B., Chase, E.B., and Mann, W.B., IV, 1983, Estimated use of water in the United States in 1980: U.S. Geological Survey Circular 1001, $56 \mathrm{p}$.

U.S. Bureau of the Census, 1981a, Advance reports, 1980 census of population and housing, Colorado: Washington, D.C., $43 \mathrm{p}$.
$1981 \mathrm{~b}$, Advance reports, 1980 census of population and housing, Ohio: Washington D.C., 43 p.

U.S. Bureau of Land Management, 1983, Public land statistics 1983: Washington, D.C., U.S. Government Printing Office, $231 \mathrm{p}$. 
SUPPLEMENTAL DATA 
WATER-QUALITY MONITORING ACTIVITIES QUESTIONNAIRE (PHASE I)

OHIO DISTRICT, U.S. GEOLOGICAL SURVEY

I. AGENCY AND PROGRAM INFORMATION

1. Agency Name:

2. Division:

3. Address:

4. Phone:

5. Contact Name

6.1 Agency Type: .1 Federal .2 State .3 County .4 City .5 Academic .6 Private .7 0ther

6.2 Area of Responsibility: .1 Statewide .2 County .3 Regional (multi-state) .4 Regional (within state) .5 City .6 Site

7.0 PROGRAM:

7.1 Type: .1 Scheduled long-term .2 Special study .3 Surface water .4 Ground water

7.2 Program Name:

7. 3 Study Name:

7.4 Number of Site(s):

7. 5 Length of Program: Dates: Start End

7.6a Was the program designed to study an area that was previously identified as being polluted? .1 Yes_. 2 No

7.6b Were data from this program the result of analyses of effluents or samples from sites in close proximity to point sources of pollution? .3 Yes .4 No 
7.7 Program Objectives: .1 Define near-natural conditions

.2 Define existing water-quality conditions

.3 Detect trends

.4 Detect effects of 1 and use

.5 Compute loads

. 6 Determine suitability for major use

.7 Determine compliance with criteria and standards

. 8 Determine effects of pollution-control programs

.9 other

7.8 Geographic Area: .1 Statewide .2 County . 3 Regional (within state)

.4 Drainage basin .5 Site-specific .6 City

.7 Other

7.9 Drainage Basin:.1 Cuyahoga

.4 Hocking

.7 Muskingum

2 Grand

.3 G. Miami

.10 Statewide

.5 L. Miami

6 Maumee

8 Sandusky

. 9 Scioto

7. 10 Sampling Locations: .1 Lat/Long 2 Mapped .3 other

7.11 Data Availability: .1 Not available .2 Restricted .3 Unrestricted

7.12 Surface Water: .1 Flow data are available at or near the collection site Yes No

.2 Data type: Instantaneous Lake Depth

7.13 Ground Water: .1 Aquifer known .2 Depth interval known

Yes Yes Daily

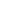


8.5 References:

\section{PHYSICAL/FIELD MEASUREMENTS}

9. $\mathrm{pH}, \mathrm{SC}, \mathrm{T}, \mathrm{DO}$, Turbidity, Alkalinity, Acidity, Color, Other

9.1

9.2

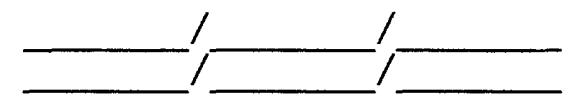

\section{CHEMICAL MEASUREMENTS}

10. MAJOR INORGANICS:

$\mathrm{Ca}, \mathrm{Mg}, \mathrm{Na}, \mathrm{K}, \mathrm{Cl}, \mathrm{F}, \mathrm{SO4}, \mathrm{N03}$, Acidity/Alkalinity, $\mathrm{pH}, \mathrm{SC}$, Other 10. 1 10.2

11. TRACE ELEMENTS:

$\mathrm{As}, \mathrm{Ba}, \mathrm{Be}, \mathrm{Cd}, \mathrm{Co}, \mathrm{Cr}, \mathrm{Cu}, \mathrm{Fe}, \mathrm{Hg}, \mathrm{Li}, \mathrm{Mn}, \mathrm{Mo}, \mathrm{Pb}, \mathrm{Se}, \mathrm{Sr}, \mathrm{V}, \mathrm{Zn}$, Other

11.1 I_ 11.2

12. NUTRIENTS:

Nitrogen Forms; Phosphorus Forms

12.1

12.2

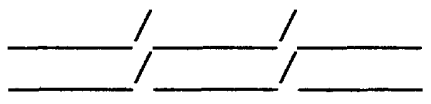

13. ORGANICS:

13.0 A11:

13.0.1

13.0.2

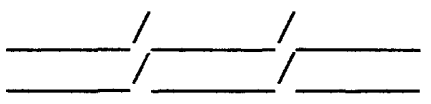

13. 1 GROSS MEASUREMENTS:

Organic/Inorganic Carbon, Detergents, $0 i 1$ \& Grease, Phenols, Tannin \& Lignin, other

13.1.1

13. 1.2

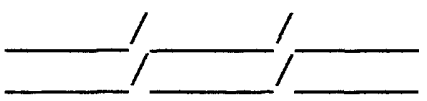

13. 2 PRIORITY POLLUTANTS:

Acid-Extractable, Base/Neutral-Extractable, Volatile, Other Major Compounds Analyzed For:

13. 2.1

13.2 .2

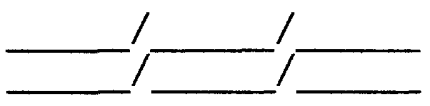


13. 3 PESTICIDES

13.3.0 A11:

13.3.0.1

13.3.0.2

13.3.1 Carbamate Insecticides:

13.3.1.1

13.3.1.2

13.3.2 Chlorophenoxy Acid Herbicides:

13.3.2.1

13.3.2.2

13.3.3 Organochlorine Insecticides:

13.3.3.1

13.3.3.2

13.3.4 Organophosphorus Insecticides:

13.3.4.1

13.3.4.2

13.3.5 Triazine Herbicides:

13.3.5.1

13.3.5.2

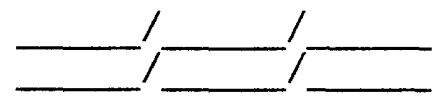

14. RADIOCHEMICAL:

14.1

14.2

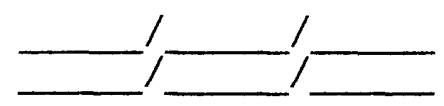

15. CHEMICAL ANALYSIS OF TISSUE:

15.1

15.2

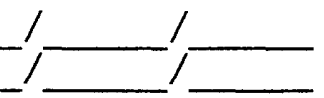

16. CHEMICAL/RADIOCHEMICAL ANALYSIS OF SEDIMENTS:

Suspended Sediment:

Bottom Material:

16.1

16.2

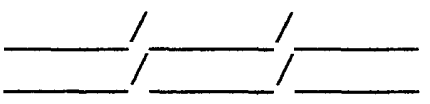


17. CHEMICAL LABORATORY AND QUALITY ASSURANCE:

: Used : Refer. : Split : Spiked : QA per- :None : Items :

: :Samples : Samples : Samples : centage : :

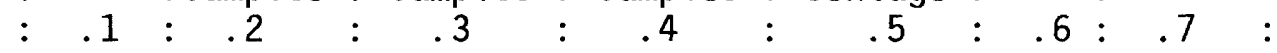

\begin{tabular}{lllllllll}
\hline 17.1 Inhouse & $:$ & $:$ & $:$ & $:$ & $:$ & $:$ & $:$ & $:$ \\
\hline 17.2 Federal & $:$ & $:$ & $:$ & $:$ & $:$ & $:$ & $:$ & $:$ \\
\hline 17.3 State & $:$ & $:$ & $:$ & $:$ & $:$ & $:$ & $:$ & $:$ \\
\hline 17.4 County & $:$ & $:$ & $:$ & $:$ & $:$ & $:$ & $:$ & $:$ \\
\hline 17.5 Private & $:$ & $:$ & $:$ & $:$ & $:$ & $:$ & $:$ & $:$ \\
\hline 17.6 Other & $:$ & $:$ & $:$ & $:$ & $:$ & $:$ & $:$ & $:$
\end{tabular}

18. 0 Sample Collection: Name

Address

Contact:

Phone

19.0 Sample Analysis: Name

Address

Contact: Phone

\section{BIOLOGICAL MEASUREMENTS}

20. BACTERIA

20.1 INDICATOR BACTERIA:

Total Coliform, Fecal Coliform, Fecal Streptoccal Bacteria, other

20.1. 1

20.1. 2

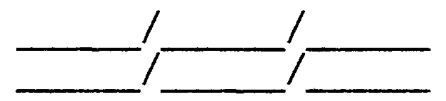


20. 2 PATHOGENIC BACTERIA:

Salmonella, Shigella, Other

20.2.1

20.2.2

20.3 OTHER BACTERIA:

20.3. 1

20.3 .2

21. PLANKTON: Phytoplankton, Zooplankton

21.1

21.2

22. BENTHIC INVERTEBRATES:

22.1

22.2

23. PERIPHYTON:

23. 1

23.2

24. MACROPHYTES:

24.1

$24.2+$

25. AQUATIC VERTEBRATES:

25.1

25.2

26. BIOASSAY:

26.1

26.2

27. OTHER:

27.1

27.2 
28. BIOLOGICAL LABORATORY AND QUALITY ASSURANCE:

$$
\begin{aligned}
& \text { : Used : Refer. : Split : Spiked : QA per- :None : Items : } \\
& \text { : } \quad \text { :Samples : Samples : Samples : centage : }
\end{aligned}
$$

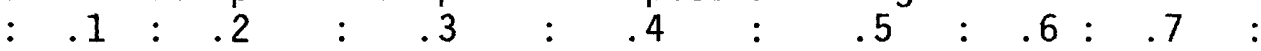

\begin{tabular}{llllllll}
\hline 28.1 Inhouse & $:$ & $:$ & $:$ & $:$ & $:$ & $:$ & $:$ \\
\hline 28.2 Federal & $:$ & $:$ & $:$ & $:$ & $:$ & $:$ & $:$ \\
\hline 28.3 State & $:$ & $:$ & $:$ & $:$ & $:$ & $:$ & $:$ \\
\hline 28.4 County & $:$ & $:$ & $:$ & $:$ & $:$ & $:$ & $:$ \\
\hline 28.5 Private & $:$ & $:$ & $:$ & $:$ & $:$ & $:$ \\
\hline
\end{tabular}

29. 0 Sample Collection: Name

Address

Contact:

Phone

30. 0 Sample Analysis: Name

Address

Contact: Phone

\section{SEDIMENT MEASUREMENTS}

31. SUSPENDED SEDIMENT:

31.1

31.2

32. BED MATERIAL:

32.1

32.2

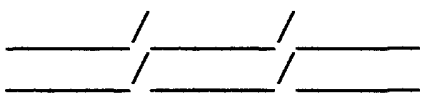


33. BED LOAD:

33.1

33.2

34. TOTAL LOAD:

34.1

34.2

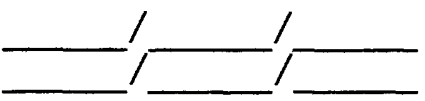

35. SEDIMENT LABORATORY AND QUALITY ASSURANCE:

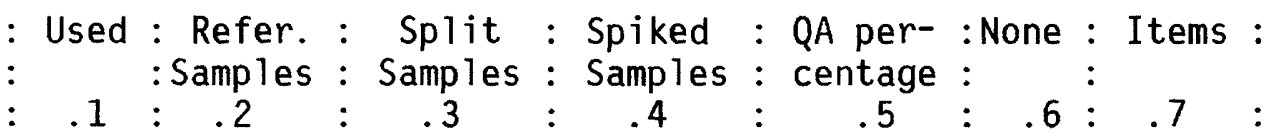

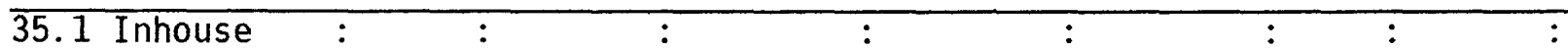

\begin{tabular}{lllllll}
\hline 35.2 Federal & $:$ & $:$ & $:$ & $:$ & $:$ & $:$
\end{tabular}

\begin{tabular}{lllllll}
\hline 35.3 State & $:$ & $:$ & $:$ & $:$ & $:$ & $:$
\end{tabular}

\begin{tabular}{lllllll}
\hline 35.4 County & $:$ & $:$ & $:$ & $:$ & $:$ & $:$
\end{tabular}

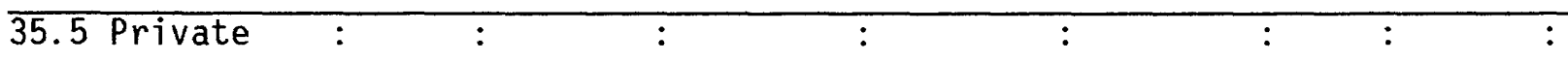

\begin{tabular}{lllllll}
\hline 35.6 other & $:$ & $:$ & $:$ & $:$ & $:$ & $:$
\end{tabular}

36. 0 Sample Collection: Name

Address

Contact:

Phone

37. 0 Sample Analysis: Name

Address

Contact:

Phone 
INDIVIDUAL COMPLETING FORM:

Name:

Address:

Phone 


\section{Water-Quality Monitoring Activities Questionnaire (Phase I) Instructions}

\section{Introduction:}

The purpose of the questionnaire is to document, in a systematic way, the current quality-of-water data-collection programs within each State. It is intended to be a general summary of these programs and not a detailed listing of all data-collection sites, sampling frequencies, or measurements made. Because it is a general summary, there will be instances when only the major or most frequent measurements made at most of the sites in a program will be listed and the specific or unusual measurements may not be reported.

The questionnaire is divided into five major sections:

I. Agency and Program Information

II. Physical/Field Measurements

III. Chemical Measurements

IV. Biological Measurements

V. Sediment Measurements

The questionnaire should be filled out for the 1984 fiscal year program. A separate questionnaire should be filled out for each major water-quality program conducted by each agency.

I. Agency and Program Information.

1. Agency Name: Give full agency/company name, including department if appropriate.

(Example: Department of the Interior, U.S. Geological Survey)

2. Division: Give division and/or section name.

(Example: Water Resources Division/Mid-Atlantic District/ Virginia State Office)

3. Address: Give complete mailing address, including State and zip code.

4. Phone: Give complete phone number, including area code; give FTS number and commercial number, if available.

5. Contact Name: Give name, title, and phone number (if different than agency's number) for individual from whom the information on the questionnaire was received. 
6. Agency.

6.1 Agency Type: Circle type of agency.

6.2 Area of Responsibility: Circle the number of the word which best describes the area of responsibility for the office in number 2 , above.

7. 0 PROGRAM:

7.1 Type: Circle .1 or .2 for the word which best describes the type of program being described and .3 or . 4 for surface- or ground-water programs.

7.2 Program Name: Give full name (plus acronym, if any).

(Example: National Stream-Quality Accounting Network, NASQAN)

7.3 Give the name of study, if appropriate.

7.4 Number of Sites: Give total number of sites in the program at which quality of water data are collected. If program is multi-State, only include sites that are within the State and that are operated by the office listed in number 2, above.

7. 5 Length of Program: Give total number of years or months for the program, and give month and year of start and end dates.

(Example: 12 years Start 10/72 End 9/84

If program is an ongoing program with no expected end date, enter " $9 / 99 "$ for ending date and number of years to date.

7.6 a \& b Self-explanatory.

7.7 Program objectives: Circle the numbers of all the phrases that describe the objective(s) of the program.

7.8 Geographic Area: Circle the number of the word that best describes the areal extent of the program or study within the state. If program or study is part of a larger, multi-State program, include this fact in section 8.4 .

7.9 Drainage Basin: Circle number of any of the drainage basins included in the sample. Cirle .5 if all drainage basins in State are included.

7.10 Sampling Locations: Check the category that best describes how sampling locations are identified. 
7.11 Data Availability: Circle the number of word that best describes the availability of the data. "Not available" means the data were proprietary or classified and not available to personnel outside the agency or company; "restricted" means the data were available to some agencies, but not available to the general public or that restrictions exist on its publication. "Unrestricted" means data that have no restrictions as to their availability or publication.

7.12 Surface Water: For surface-water-quality studies, check whether or not flow data are available. If "yes," note the type of data available.

7.13 Ground Water: Check yes or no, as appropriate.

\subsection{Support:}

8.1 Cooperator(s): List all agencies that supply services and/or funding for the program.

8.2 Funding: List the appropriate total amount of funds expended on the quality-of-water part of the program or study. If services are supplied as part of the funding, estimate the dollar value of these services.

8.3 Funding source(s): Give approximate percentage(s) of funds in section 8.2 that come from these sources.

(Example: .150 Federal and .250 State would be a 50-50 cooperative project between a Federal and a State agency.)

8.4 Comments: Include any additional information on the problem, scope, and objectives of the program or study not reported in section 7. If appropriate, include a short historical summary of the project, describing the types of data that have been collected in the past, the fluctuations in the size of the program over the years, and what types of analyses and interpretations of the data have been made.

8.5 References: Note any reports or series of reports describing the study and results, including reports in which the data have been published and/or interpretated. 
II. $-V$. Measurements

1. Each measurement subcategory has several lines in the format of "_. 1ines (SPL). If additional lines are needed, add the needed lines under those listed on the form and number them accordingly. the sampling program lines are filled out as follows: (See Example 1)

The SPL has three parts -- A, B, and C -- and is formated as:

Part A $\mathrm{xxa}$
Part B
yy

/ yy
Part C bc

Part A contains information on the number and type of site (a site is the location of sample collection). It is formated as:

$x x a$, where $x x$ is the number of sites and $a$ is a code for the type of sites.

Site type codes are:

$s=$ surface water

$\mathrm{g}=$ ground water

$\mathrm{p}=$ precipitation

$\mathrm{e}=\mathrm{effluent}$

Part B contains information on the frequency of measurements and is formated as:

yy, where yy is the number of samples per year per site.

(Note: If samples are collected or an event basis, estimate the approximate number of samples to be taken during the year.)

Part $C$ contains information on the storage and publication of the measurements and is formated as:

$b c$, where $b$ and $c$ are storage and publication codes. If more than one storage code fits the data, list the most appropriate code.

(Example: Data stored in WATSTORE would also be machine readable and might also be in STORET. However, WATSTORE is the primary storage file for the data; therefore, the code " $w$ " would be used) 
Publication codes:

$p=$ published

$\mathrm{n}=$ not published
Storage codes:

$h=$ hard copy, in agency files

$\mathrm{m}=$ machine $\mathrm{readab}$ le/automated

$w=$ WATSTORE

$S=$ STORET

0 other ADP file

2. Items 9-12: Circle the measurements made and fill in the SPL. If more than one SPL is required and three or less measurements are made at only some of the sites, list these measurements after the appropriate SPL. (See Example 2, item 11.2.)

3. Item 13: If the same SPL would be appropriate for all categories in 13.1-13.3, then use that SPL for 13.0 and do not complete 13.1-13.3. If all measurements are not made in 13.1-13.3, complete the individual sections as appropriate.

4. Items $13.2,13.3,14-16$ : If the analysis is for specific compounds or pesticides, such as dioxin or DDT, list these compounds after the corresponding SPL. If a general analysis is done to determine what compounds are present, do not list findings, only fill out SPL.

5. Items 17-19, 28-30, 35-37: These items refer to the Chemical (17), Biological (28), and Sediment (35) support organizations and laboratories used and the quality-assurance programs associated with them.

Place a check ( ) in column .1 (used) for each type of laboratory used. If more than one type of laboratory is used, indicate the type of measurements made by each type laboratory by placing the questionnaire item number in column . 7 for each type measurement made by each type laboratory. (See Example 3.)

Place a check ( ) in columns .2,.3, and(or) .4 or .6, where appropriate for each type laboratory.

Enter the percentage of work for quality assurance in column .5 ( 1 ist as percent). Example, if 1 out of every 10 samples are split, then the percentage for quality assurance would be 10 percent, and "10" would be placed in column . 5 .

6. Items 20-27 and 31-34: Fill in the appropriate SPL's for the type of biological and(or) sediment measurements made under the program. Provide names and addresses of support organization undertaking the sampling and of the laboratory carrying out the analyses. Provide the name and title of the person most familiar with the procedures used for this study. 
Examp 1e-1

A sample SPL would be:

$10 \mathrm{~s} / 12 / \mathrm{pw}$

this would be: $\quad 10$ surface-water sites

12 samples are collected per year, and

the data are published and stored in WATSTORE

\section{Example-2}

III. Chemical Measurements

10. Major ingrganics.

(Ca) Mg, $\mathrm{Na}$ K, (C7) $\mathrm{F}, \mathrm{S} 04, \mathrm{N03}$, Acidity/Alkalinity, pH, SC, other

$\begin{array}{ll}10.1 & \frac{10 s^{\prime}}{10} / \frac{12}{12} / \frac{p w}{p w}\end{array}$

11. Trace Elements:

$\mathrm{As}, \mathrm{Ba}, \mathrm{Be}, \mathrm{Cd}, \mathrm{Co}, \mathrm{Cr}, \mathrm{Cu}, \mathrm{Fe}, \mathrm{Hg}, \mathrm{Li}, \mathrm{Mn}, \mathrm{Mo}, \mathrm{Pb}, \mathrm{Se}, \mathrm{Sr}, \mathrm{V}, \mathrm{Zn}$,

11.1 10s/12/Pw

$11.2 \log \sqrt{12} / \mathrm{NW} A \mathrm{~s}, \mathrm{Hg}, \mathrm{Pb}$

12. Nutrients:

Nitrogen forms; Phosphorus Forms

12.1

12.2

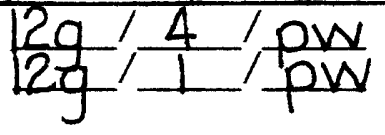

Notes

10. Both the surface-water and ground-water sites have basically the same measurements made; therefore, only the sampling program lines are filled out and the measurements have been circled.

11. All the trace elements listed are sampled at the surface-water sites (line 11.1) but only $\mathrm{As}, \mathrm{Hg}$, and $\mathrm{Pb}$ are measured at the ground-water sites (1 ine 11.2).

12. A11 the nutrients 1 isted are measured and two different frequencies are used. This program would have a total of 48 ground-water stations, 12 sampled quarterly and 36 sampled yearly. 
Table 7. Organizations with water-quality data-collection programs active in Colorado during 1984 and the property and constituent groups for which data were reported

[S, surface-water-quality analyses; G, ground-water-quality analyses; --, no data]

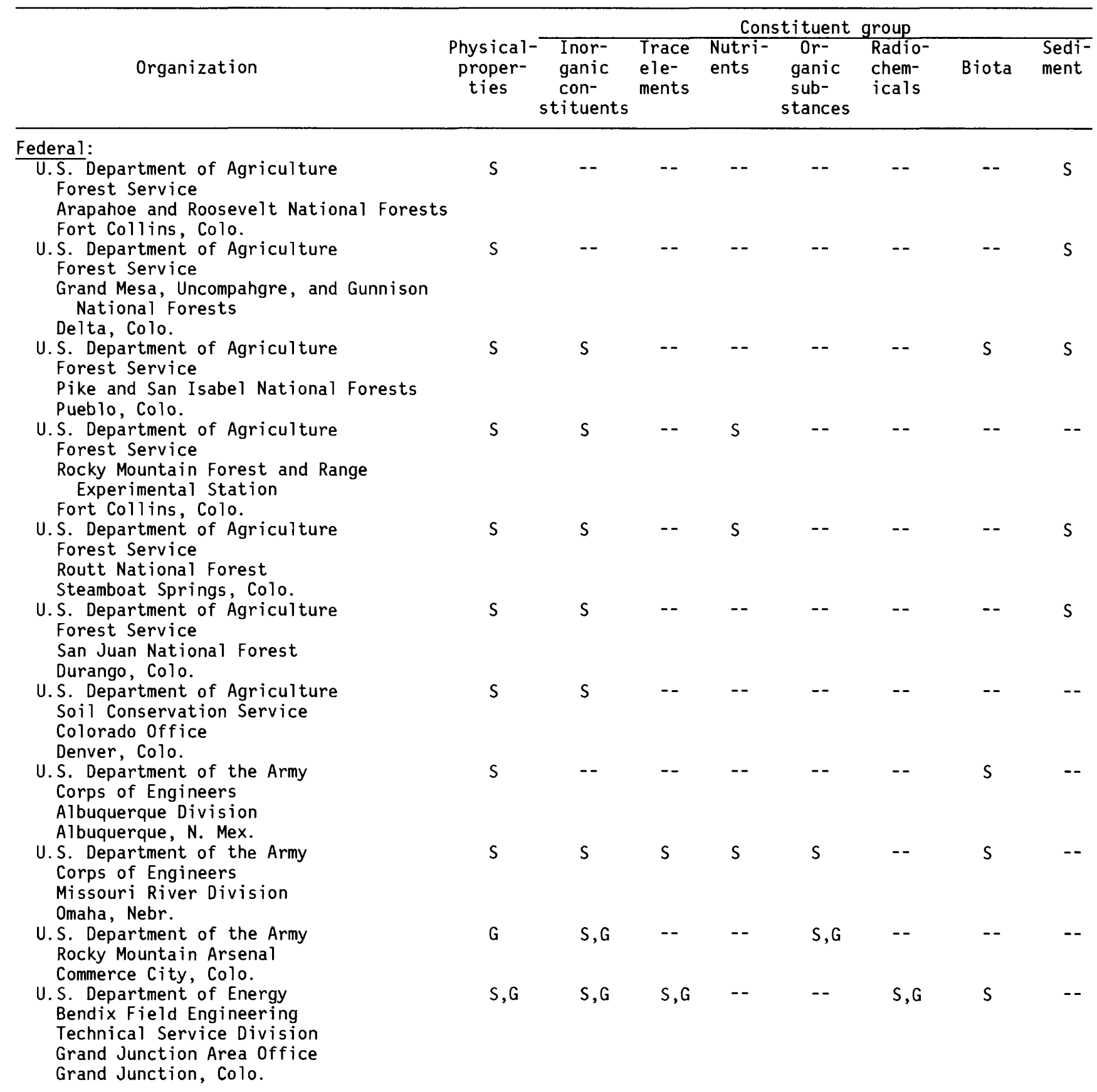


Table 7. Organizations with water-quality data-collection programs active in Colorado during 1984 and the property and constituent groups for which data were reported -Continued

\begin{tabular}{|c|c|c|c|c|c|c|c|c|}
\hline \multirow[b]{2}{*}{ Organization } & \multirow[b]{2}{*}{$\begin{array}{c}\text { Physical- } \\
\text { proper- } \\
\text { ties }\end{array}$} & \multicolumn{7}{|c|}{ Constituent group } \\
\hline & & $\begin{array}{l}\text { Inor- } \\
\text { ganic } \\
\text { con- } \\
\text { stituents }\end{array}$ & $\begin{array}{l}\text { Trace } \\
\text { ele- } \\
\text { ments }\end{array}$ & $\begin{array}{l}\text { Nutri- } \\
\text { ents }\end{array}$ & $\begin{array}{c}\text { Or- } \\
\text { ganic } \\
\text { sub- } \\
\text { stances }\end{array}$ & $\begin{array}{l}\text { Radio- } \\
\text { chem- } \\
\text { icals }\end{array}$ & Biota & $\begin{array}{l}\text { Sedi- } \\
\text { ment }\end{array}$ \\
\hline
\end{tabular}

Federal--Continued:

U.S. Department of Energy Uranium Mill Tailings Project

G

Jacobs Engineering

Albuquerque, N. Mex.

U.S. Department of the Interior Bureau of Land Management

Canon City District

Canon City, Colo.

U.S. Department of the Interior Bureau of Land Management Division of Lands and Renewable Resources Grand Junction District Office Grand Junction, Colo.

U.S. Department of the Interior Bureau of Land Management Montrose District Montrose, Colo.

U.S. Department of the Interior Bureau of Land Management oil Shale Project office Grand Junction, Colo.

U.S. Department of the Interior Bureau of Reclamation Operations and Maintenance Division Alamosa, Colo.

U.S. Department of the Interior Bureau of Reclamation Planning Division Upper Colorado Region Salt Lake City, Utah.

U.S. Department of the Interior Geological Survey Denver, Colo.

U.S. Department of the Interior National Park Service Water Resources Field Support Laboratory Fort Collins, Colo.

U.S. Department of the Interior Office of Surface Mining Albuquerque, N. Mex.

U.S. Environmental Protection Agency, Region VIII

Air and Waste Management Division Denver, Colo.

U.S. Environmental Protection Agency, Region VIII

Environmental Services Division

Denver, Colo.

U.S. Environmental Protection Agency, Region VIII

Water Management Division

Denver, Colo.
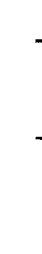

$\begin{array}{llllllll}G & G & G & -- & G & G & -- & - \\ S & S & -- & S & -- & -- & S & - \\ S & S & S & -- & -- & -- & --\end{array}$

G $\quad$ G $\quad$ G $\quad$ G $\quad$ G

G $\quad$ G $\quad$ G $\quad--$

$S, G \quad S, G \quad S \quad S$

S,G $\quad S, G \quad S, G \quad S, G \quad S, G \quad S, G \quad S, G \quad S$

$\begin{array}{llllllll}S & S & S & S & S & S & S & S\end{array}$

$\begin{array}{llllllll}S & S & S & S & S & S & S & - \\ \text { S,G } & \text { S,G } & \text { S,G } & -- & \text { S,G } & -- & -- & -\end{array}$


Table 7. Organizations with water-quality data-collection programs active in Colorado during 1984 and the property and constituent groups for which data were reported -Continued

\begin{tabular}{|c|c|c|c|c|c|c|c|c|}
\hline \multirow[b]{2}{*}{ Organization } & \multirow[b]{2}{*}{$\begin{array}{l}\text { Physical- } \\
\text { proper- } \\
\text { ties }\end{array}$} & \multicolumn{7}{|c|}{ Constituent group } \\
\hline & & $\begin{array}{l}\text { Inor- } \\
\text { ganic } \\
\text { con- } \\
\text { stituents }\end{array}$ & $\begin{array}{l}\text { Trace } \\
\text { ele- } \\
\text { ments }\end{array}$ & $\begin{array}{l}\text { Nutri- } \\
\text { ents }\end{array}$ & $\begin{array}{l}\text { Or- } \\
\text { ganic } \\
\text { sub- } \\
\text { stances }\end{array}$ & $\begin{array}{l}\text { Radio- } \\
\text { chem- } \\
\text { icals }\end{array}$ & Biota & $\begin{array}{l}\text { Sedi- } \\
\text { ment }\end{array}$ \\
\hline \multicolumn{9}{|l|}{ State: } \\
\hline $\begin{array}{l}\text { Colorado Department of Health } \\
\text { Environmental Health Division } \\
\text { Denver, Colo. }\end{array}$ & $\mathrm{S}$ & $\mathrm{S}, \mathrm{G}$ & $S, G$ & -- & $\mathrm{S}$ & -- & -- & -- \\
\hline $\begin{array}{l}\text { Colorado Department of Health } \\
\text { Environmental Services Division } \\
\text { Denver, Colo. }\end{array}$ & -- & -- & -- & -- & -- & -- & $\mathrm{S}, \mathrm{G}$ & $S$ \\
\hline $\begin{array}{l}\text { Colorado Department of Health } \\
\text { Radiation Control Division } \\
\text { Denver, Colo. }\end{array}$ & -- & $S, G$ & $S, G$ & -- & -- & $S, G$ & -- & -- \\
\hline $\begin{array}{l}\text { Colorado Department of Health } \\
\text { Waste Management Division } \\
\text { Denver, Colo. }\end{array}$ & -- & G & G & -- & G & -- & -- & -- \\
\hline $\begin{array}{l}\text { Colorado Department of Health } \\
\text { Water Quality Control Division } \\
\text { Denver, Colo. }\end{array}$ & $S$ & $S, G$ & $\mathrm{~S}$ & $\mathrm{~S}, \mathrm{G}$ & $S$ & $S$ & $S$ & -- \\
\hline $\begin{array}{l}\text { Colorado Department of Highways } \\
\text { Division of Transportation Planning } \\
\text { Denver, Colo. }\end{array}$ & $S$ & $S$ & $\mathrm{~S}$ & -- & -- & -- & -- & $S$ \\
\hline $\begin{array}{l}\text { Colorado Department of Natural Resources } \\
\text { Division of Mined Land Reclamation } \\
\text { Denver, Colo. }\end{array}$ & $\mathrm{S}, \mathrm{G}$ & $\mathrm{S}, \mathrm{G}$ & $\mathrm{S}, \mathrm{G}$ & $\mathrm{S}, \mathrm{G}$ & $\mathrm{S}, \mathrm{G}$ & $\mathrm{S}, \mathrm{G}$ & -- & $S$ \\
\hline \multicolumn{9}{|l|}{ Regional--Intrastate: } \\
\hline $\begin{array}{l}\text { Colorado River Water Conservation District } \\
\text { Glenwood Springs, Colo. }\end{array}$ & -- & $S$ & $\mathrm{~S}$ & $S$ & -- & -- & -- & $S$ \\
\hline $\begin{array}{l}\text { Denver Water Department } \\
\text { Wastewater Management Division } \\
\text { Quality Control Laboratory } \\
\text { Denver, Colo. }\end{array}$ & $\mathrm{S}$ & $S$ & $S$ & $S$ & -- & -- & $S$ & -- \\
\hline $\begin{array}{l}\text { Metropolitan Denver Sewage Disposal } \\
\text { District Number } 1 \\
\text { Department of Laboratory Services } \\
\text { Denver, Colo. }\end{array}$ & $S$ & $S$ & $S$ & $S$ & $S$ & -- & $S$ & -- \\
\hline $\begin{array}{l}\text { Project Seven Water Authority } \\
\text { Montrose, Colo. }\end{array}$ & $S$ & $S$ & $S$ & $S$ & -- & -- & -- & -- \\
\hline \multicolumn{9}{|l|}{ Local: } \\
\hline $\begin{array}{l}\text { Arvada, City of } \\
\text { Department of Public Works } \\
\text { Utilities Division. }\end{array}$ & -- & -- & -- & $S$ & -- & -- & -- & -- \\
\hline $\begin{array}{l}\text { Boulder, City of } \\
\text { Department of Public Works } \\
\text { Utilities Division. }\end{array}$ & $S$ & $S$ & -- & -- & -- & -- & -- & -- \\
\hline $\begin{array}{l}\text { Brighton, City of } \\
\text { Utility Department } \\
\text { Water Division. }\end{array}$ & -- & $\mathrm{G}$ & -- & -- & G & -- & -- & -- \\
\hline $\begin{array}{l}\text { Broomfield, City of } \\
\text { Department of Public Works } \\
\text { Environmental Division. }\end{array}$ & $S$ & $S$ & -- & $S$ & -- & $S$ & $S$ & -- \\
\hline $\begin{array}{l}\text { Colorado City, City of } \\
\text { Water and Sanitation District. }\end{array}$ & $S$ & $S$ & $S$ & -- & $S$ & -- & $S$ & $S$ \\
\hline
\end{tabular}


Table 7. Organizations with water-quality data-collection programs active in Colorado during 1984 and the property and constituent groups for which data were reported - Continued

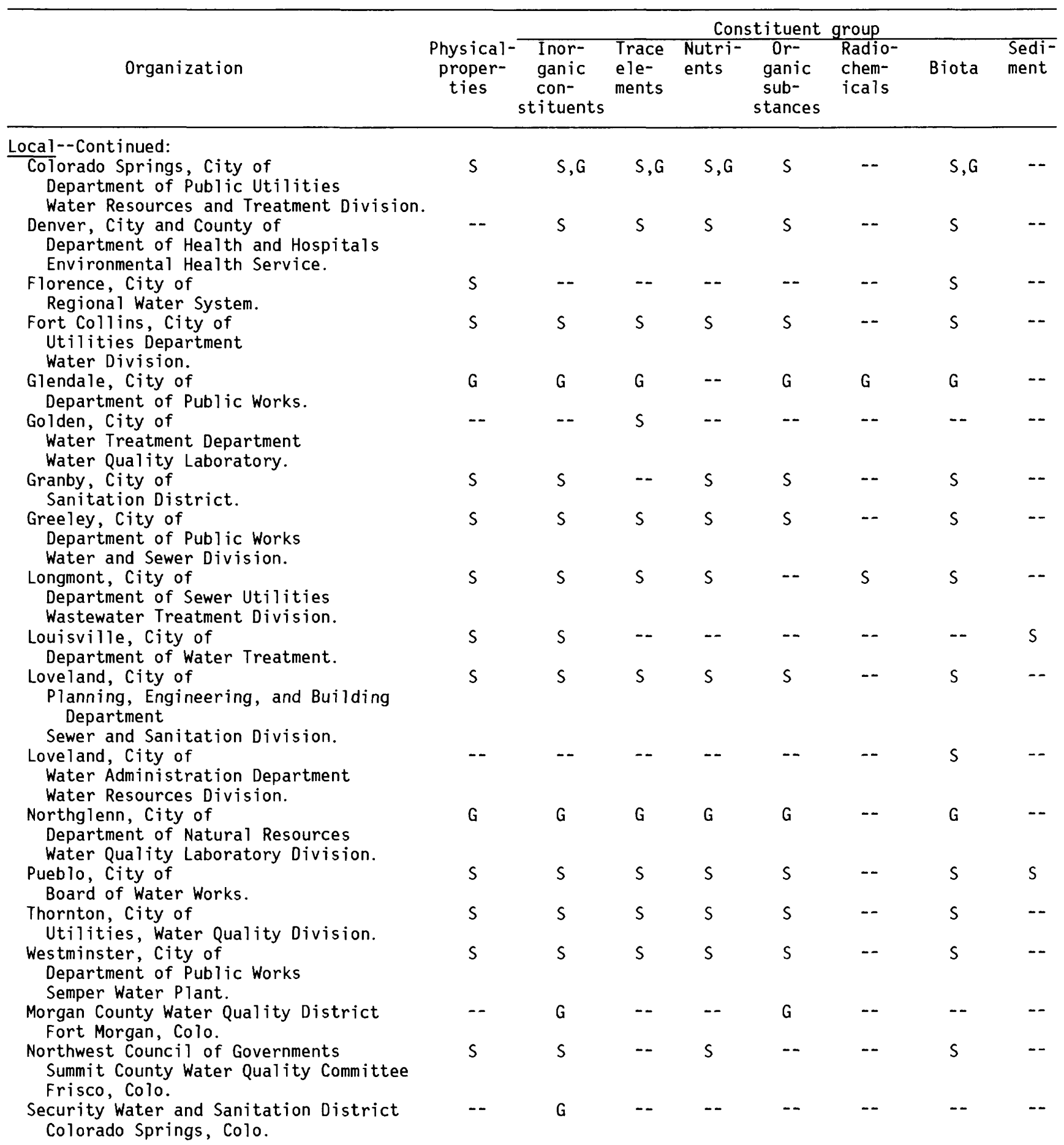


Table 7. Organizations with water-quality data-collection programs active in Colorado during 1984 and the property and constituent groups for which data were reported -Continued

\begin{tabular}{|c|c|c|c|c|c|c|c|c|}
\hline Organization & $\begin{array}{l}\text { Physical- } \\
\text { proper- } \\
\text { ties }\end{array}$ & $\begin{array}{l}\text { Inor- } \\
\text { ganic } \\
\text { con- } \\
\text { stituents }\end{array}$ & $\begin{array}{l}\text { Trace } \\
\text { ele- } \\
\text { ments }\end{array}$ & $\begin{array}{l}\text { Con } \\
\text { Nutri- } \\
\text { ents }\end{array}$ & $\begin{array}{l}\text { stituent } \\
\text { Or- } \\
\text { ganic } \\
\text { sub- } \\
\text { stances }\end{array}$ & $\begin{array}{l}\text { group } \\
\text { Radio- } \\
\text { chem- } \\
\text { icals }\end{array}$ & Biota & $\begin{array}{l}\text { Sedi- } \\
\text { ment }\end{array}$ \\
\hline \multirow{2}{*}{$\begin{array}{l}\text { Local--Continued: } \\
\text { South Adams Water and Sanitation District } \\
\text { Commerce City, Colo. } \\
\text { Weld County Health Department } \\
\text { Health Protection Service } \\
\text { Greeley, Colo. }\end{array}$} & $\cdots$ & G & G & G & G & G & - & -- \\
\hline & G & G & G & G & G & - & G & - \\
\hline \\
\hline $\begin{array}{l}\text { University of Colorado--Boulder } \\
\text { Department of Environmental, Population, } \\
\text { and Organismic Biology } \\
\text { Boulder, Colo. }\end{array}$ & 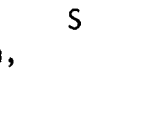 & $S$ & -- & - & - & -- & - & $S$ \\
\hline $\begin{array}{l}\text { University of Colorado--Denver } \\
\text { Center for Environmental Sciences } \\
\text { Denver, Colo. } \\
\text { Western State College } \\
\text { Biology Department } \\
\text { Gunnison, Colo. }\end{array}$ & $S, G$ & $S, G$ & $S, G$ & $S, G$ & - & - & -- & - \\
\hline
\end{tabular}


Table 8. Organizations with water-quality data-collection programs active in Ohio during 1984 and the property and constituent groups for which data were reported

[S, surface-water analyses; G, ground-water analyses; --, no data]

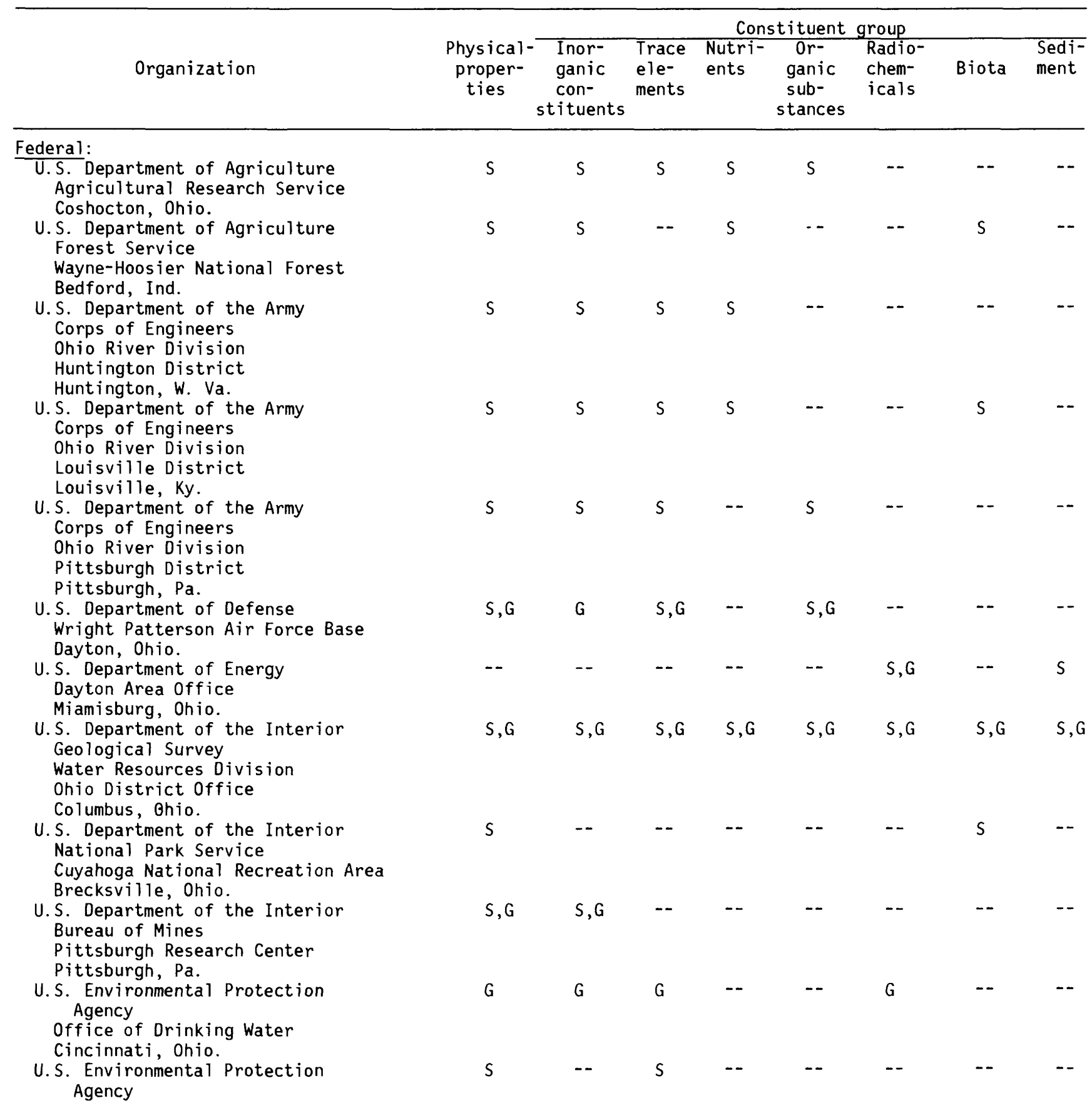

Eastern District Office

Westlake, Ohio. 
Table 8. Organizations with water-quality data-collection programs active in Ohio during 1984 and the property and constituent groups for which data were reported -Continued

\begin{tabular}{|c|c|c|c|c|c|c|c|c|}
\hline Organization & $\begin{array}{l}\text { Physical- } \\
\text { proper- } \\
\text { ties }\end{array}$ & $\begin{array}{l}\text { Inor- } \\
\text { ganic } \\
\text { con- } \\
\text { stituents }\end{array}$ & $\begin{array}{l}\text { Trace } \\
\text { ele- } \\
\text { ments }\end{array}$ & $\begin{array}{l}\text { Cons } \\
\text { Nutri- } \\
\text { ents }\end{array}$ & $\begin{array}{c}\text { stituent } \\
\text { Or- } \\
\text { ganic } \\
\text { sub- } \\
\text { stances }\end{array}$ & $\begin{array}{l}\text { group } \\
\text { Radio- } \\
\text { chem- } \\
\text { icals }\end{array}$ & Biota & $\begin{array}{l}\text { Sedi- } \\
\text { ment }\end{array}$ \\
\hline \multicolumn{9}{|l|}{ State: } \\
\hline $\begin{array}{l}\text { Ohio Environmental Protection Agency } \\
\text { Columbus, Ohio. }\end{array}$ & $S, G$ & $S, G$ & $S, G$ & $S, G$ & $S, G$ & $S, G$ & $\mathrm{~S}$ & $\mathrm{~S}$ \\
\hline $\begin{array}{l}\text { Ohio Department of Health } \\
\text { Columbus, Ohio. }\end{array}$ & G & -- & -- & -- & -- & -- & G & -- \\
\hline $\begin{array}{l}\text { Ohio Department of Natural Resources } \\
\text { Columbus, Ohio. }\end{array}$ & $S, G$ & $S, G$ & $S, G$ & $S$ & -- & -- & $S$ & $S$ \\
\hline $\begin{array}{l}\text { Ohio Department of Transportation } \\
\text { Columbus, Ohio. }\end{array}$ & $S$ & $S$ & - & $S$ & -- & -- & $S$ & -- \\
\hline \multicolumn{9}{|l|}{ Regional--Interstate: } \\
\hline $\begin{array}{l}\text { Ohio River Valley Water Sanitation } \\
\text { Commission } \\
\text { Cincinnati, Ohio. }\end{array}$ & $S$ & $S$ & $S$ & $S$ & $S$ & -- & $\mathrm{s}$ & -- \\
\hline \multicolumn{9}{|l|}{ Local: } \\
\hline $\begin{array}{l}\text { Akron, City of } \\
\text { Water Supply. }\end{array}$ & $S$ & $S$ & $S$ & $S$ & $S$ & -- & $S$ & -- \\
\hline $\begin{array}{l}\text { Barberton, City of } \\
\text { Water Supply. }\end{array}$ & $S$ & $S$ & $S$ & $S$ & $\mathrm{~S}$ & -- & $S$ & -- \\
\hline $\begin{array}{l}\text { Bowling Green, City of } \\
\text { Water Department. }\end{array}$ & $S$ & $S$ & -- & - & $S$ & -- & -- & -- \\
\hline $\begin{array}{l}\text { Canton, City of } \\
\text { Water Division. }\end{array}$ & G & G & G & G & G & -- & G & -- \\
\hline $\begin{array}{l}\text { Cincinnati, City of } \\
\text { Waterworks. }\end{array}$ & $S, G$ & $S, G$ & $S, G$ & -- & $S, G$ & -- & -- & -- \\
\hline $\begin{array}{l}\text { Cleveland, City of } \\
\text { Water Division. }\end{array}$ & $S$ & $S$ & $\mathrm{~S}$ & $S$ & -- & -- & -- & -- \\
\hline $\begin{array}{l}\text { Columbus, City of } \\
\text { Division of Water. }\end{array}$ & $S, G$ & $S, G$ & $S$ & $\mathrm{~S}$ & $S$ & -- & $S, G$ & -- \\
\hline $\begin{array}{l}\text { Cuyahoga Falls, City of } \\
\text { Division of Water }\end{array}$ & G & G & G & -- & -- & -- & -- & -- \\
\hline $\begin{array}{l}\text { Dayton, City of } \\
\text { Division of Water. }\end{array}$ & -- & -- & G & -- & G & -- & -- & -- \\
\hline $\begin{array}{l}\text { Elyria, City of } \\
\text { Division of Water. }\end{array}$ & $S$ & $S$ & - & -- & -- & -- & $S$ & $\cdots$ \\
\hline $\begin{array}{l}\text { Findlay, City of } \\
\text { Division of Water. }\end{array}$ & $S$ & $S$ & $S$ & -- & -- & -- & -- & -- \\
\hline $\begin{array}{l}\text { Hamilton, City of } \\
\text { Division of water. }\end{array}$ & G & $\mathrm{G}$ & $\mathrm{G}$ & $\mathrm{G}$ & -- & -- & $\mathbf{G}$ & -- \\
\hline $\begin{array}{l}\text { Kent, City of } \\
\text { Division of Water. }\end{array}$ & G & $\mathrm{G}$ & -- & -- & -- & -- & -- & -- \\
\hline $\begin{array}{l}\text { Lima, City of } \\
\text { Division of water. }\end{array}$ & $S$ & -- & -- & -- & -- & -- & -- & -- \\
\hline $\begin{array}{l}\text { Lorain, City of } \\
\text { Utilities Department. }\end{array}$ & $S$ & $S$ & $S$ & $S$ & -- & -- & -- & -- \\
\hline $\begin{array}{l}\text { Newark, City of } \\
\text { Division of Water. }\end{array}$ & $S$ & $S$ & $S$ & $S$ & -- & -- & -- & -- \\
\hline $\begin{array}{l}\text { Springfield, City of } \\
\text { Division of Water. }\end{array}$ & $\mathrm{G}$ & $G$ & $\mathrm{G}$ & -- & -- & -- & $\mathrm{G}$ & -- \\
\hline
\end{tabular}


Table 8. Organizations with water-quality data-collection programs active in Ohio during 1984 and the property and constituent groups for which data were reported -Continued

\begin{tabular}{|c|c|c|c|c|c|c|c|c|}
\hline \multirow[b]{2}{*}{ Organization } & \multirow[b]{2}{*}{$\begin{array}{l}\text { Physical- } \\
\text { proper- } \\
\text { ties }\end{array}$} & \multicolumn{7}{|c|}{ Constituent group } \\
\hline & & $\begin{array}{l}\text { Inor- } \\
\text { ganic } \\
\text { con- } \\
\text { stituents }\end{array}$ & $\begin{array}{l}\text { Trace } \\
\text { ele- } \\
\text { ments }\end{array}$ & $\begin{array}{l}\text { Nutri- } \\
\text { ents }\end{array}$ & $\begin{array}{l}\text { Or- } \\
\text { ganic } \\
\text { sub- } \\
\text { stances }\end{array}$ & $\begin{array}{l}\text { Radio- } \\
\text { chem- } \\
\text { icals }\end{array}$ & Biota & $\begin{array}{l}\text { Sedi- } \\
\text { ment }\end{array}$ \\
\hline \multicolumn{9}{|l|}{ Local--Continued: } \\
\hline $\begin{array}{l}\text { Toledo, City of } \\
\text { Department of Public Utilities. }\end{array}$ & $\mathrm{s}$ & $\mathrm{s}$ & $\mathrm{s}$ & -- & $\mathrm{s}$ & $\mathrm{s}$ & $\mathrm{s}$ & -- \\
\hline $\begin{array}{l}\text { Warren, City of } \\
\text { Division of Water. }\end{array}$ & $S$ & $\mathrm{~s}$ & $\mathrm{~s}$ & $\mathrm{~s}$ & -- & -- & $\mathrm{s}$ & -- \\
\hline $\begin{array}{l}\text { Zanesville, City of } \\
\text { Division of Water. }\end{array}$ & G & G & G & G & G & -- & -- & -- \\
\hline $\begin{array}{l}\text { Hamilton County Park District } \\
\text { Resource Quality Department } \\
\text { Cincinnati, Ohio. }\end{array}$ & $S$ & -- & -- & $S$ & -- & -- & - & -- \\
\hline $\begin{array}{l}\text { Wood County } \\
\text { Sanitary Engineer Department } \\
\text { Bowl ing Green, Ohio. }\end{array}$ & -- & G & -- & -- & G & -- & -- & -- \\
\hline \multicolumn{9}{|l|}{ Academic institutions: } \\
\hline $\begin{array}{l}\text { Heidelberg College } \\
\text { Water Quality Laboratory } \\
\text { Tiffin, Ohio. }\end{array}$ & $S$ & $S$ & -- & $S$ & $S$ & - & -- & $S$ \\
\hline $\begin{array}{l}\text { Kent State University } \\
\text { Biological Sciences Department } \\
\text { Kent, Ohio. }\end{array}$ & $S$ & -- & -- & $S$ & -- & -- & $S$ & -- \\
\hline $\begin{array}{l}\text { Miami University } \\
\text { Department of Zoology } \\
\text { Oxford. Ohio }\end{array}$ & -- & $\mathrm{s}$ & $\mathrm{s}$ & -- & -- & -- & $\mathrm{s}$ & -- \\
\hline $\begin{array}{l}\text { Ohio State University } \\
\text { Agricultural Engineering Department } \\
\text { Columbus. Ohio. }\end{array}$ & $S$ & $S$ & $S$ & $S$ & $S$ & - & $S$ & -- \\
\hline $\begin{array}{l}\text { University of Cincinnati } \\
\text { Biological Sciences Department } \\
\text { Institute of Environmental Health } \\
\text { Cincinnati, Ohio. }\end{array}$ & $S$ & -- & -- & -- & $S$ & -- & $S$ & - \\
\hline $\begin{array}{l}\text { Wright State University } \\
\text { Department of Geological Sciences } \\
\text { Dayton, Ohio. }\end{array}$ & G & G & G & -- & G & -- & -- & -- \\
\hline
\end{tabular}


Table 9. U.S. Geological Survey laboratory codes, detection limits, and costs for measurements and analyses used to determine estimated laboratory costs

[--,not applicable; $\star$, varies with organic species, range $5.0-30.0 ; \star \star$, varies with organic species, range, $0.01-1.0 ; \mathrm{mg} / \mathrm{L}, \mathrm{milligram}$ per liter; $\mu \mathrm{S} / \mathrm{cm}$, microsiemens per centimeter at $25^{\circ}$ Celsius; C, Celsius; $\mu \mathrm{g} / \mathrm{g}$, micrograms per gram; $\mu \mathrm{g} / \mathrm{L}$, micrograms per liter; $\mathrm{mL}$, milliliters]

\begin{tabular}{llc}
\hline $\begin{array}{c}\text { Laboratory } \\
\text { code }\end{array}$ & $\begin{array}{c}\text { Property or } \\
\text { constituent }\end{array}$ & $\begin{array}{c}\text { Detection } \\
\text { limit }\end{array}$ \\
\hline
\end{tabular}

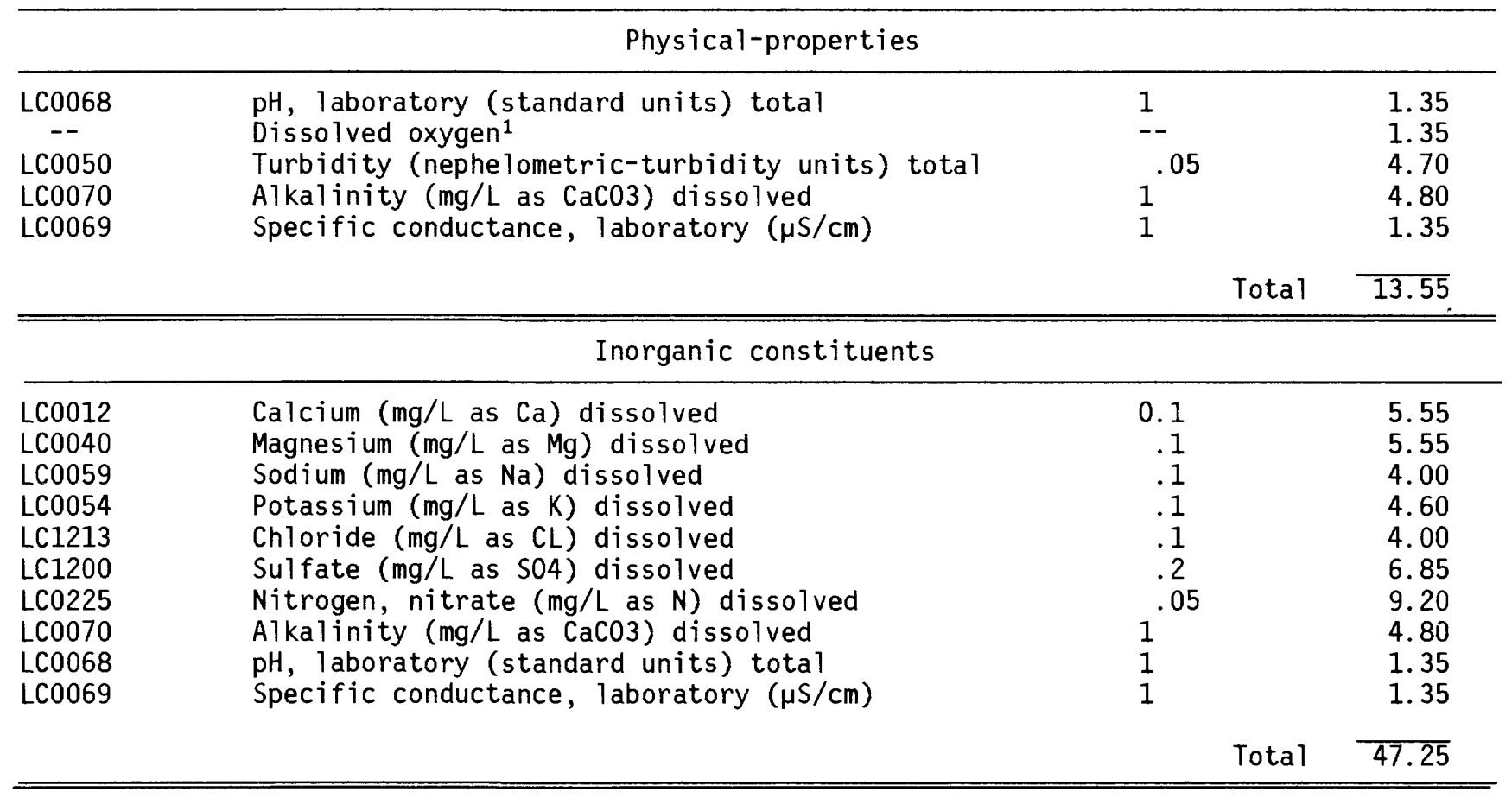

\section{Trace elements}

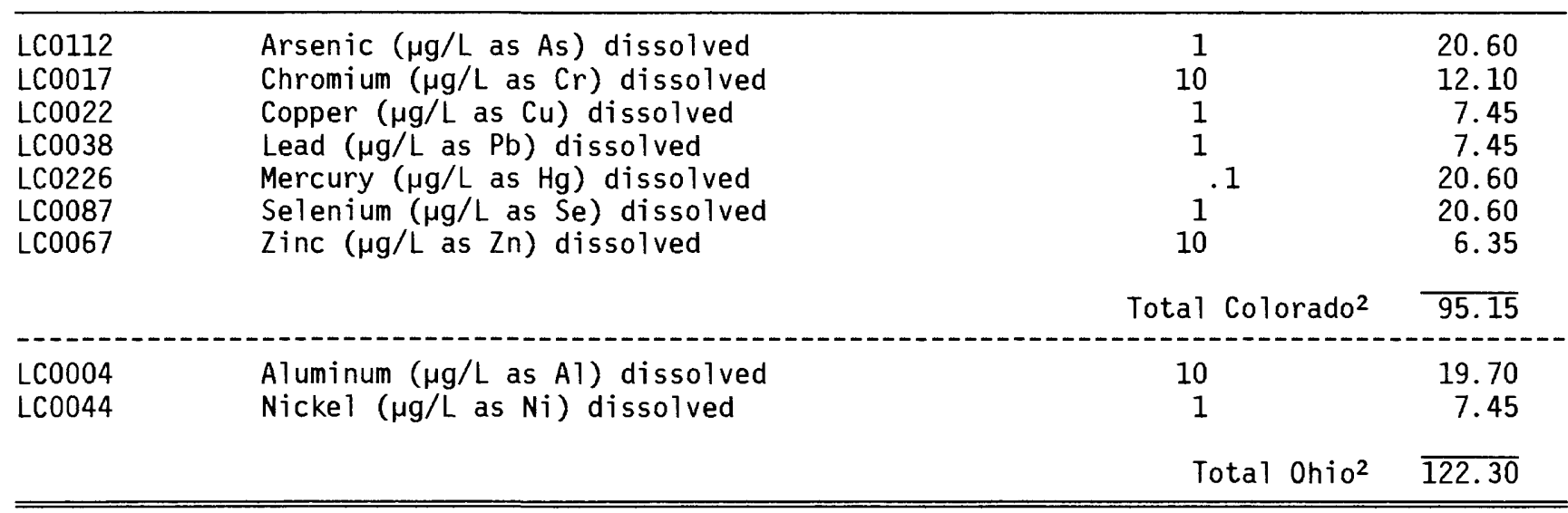

\section{Major metals}

\begin{tabular}{llrr}
\hline LC0172 & Iron $(\mu \mathrm{g} / \mathrm{L}$ as Fe) dissolved & 10 & 4.60 \\
$\mathrm{LC} 0042$ & Manganese $(\mu \mathrm{g} / \mathrm{L}$ as Mn) dissolved & 10 & 4.60 \\
& & 9.20 \\
\hline \hline
\end{tabular}


Table 9. U.S. Geological Survey laboratory codes, detection limits, and costs for measurements and analyses used to determine estimated laboratory costs-Continued

\begin{tabular}{llc}
\hline $\begin{array}{l}\text { Laboratory } \\
\text { code }\end{array}$ & $\begin{array}{l}\text { Property or } \\
\text { constituent }\end{array}$ & $\begin{array}{c}\text { Detection } \\
\text { limit }\end{array}$ \\
\end{tabular}

Nutrients

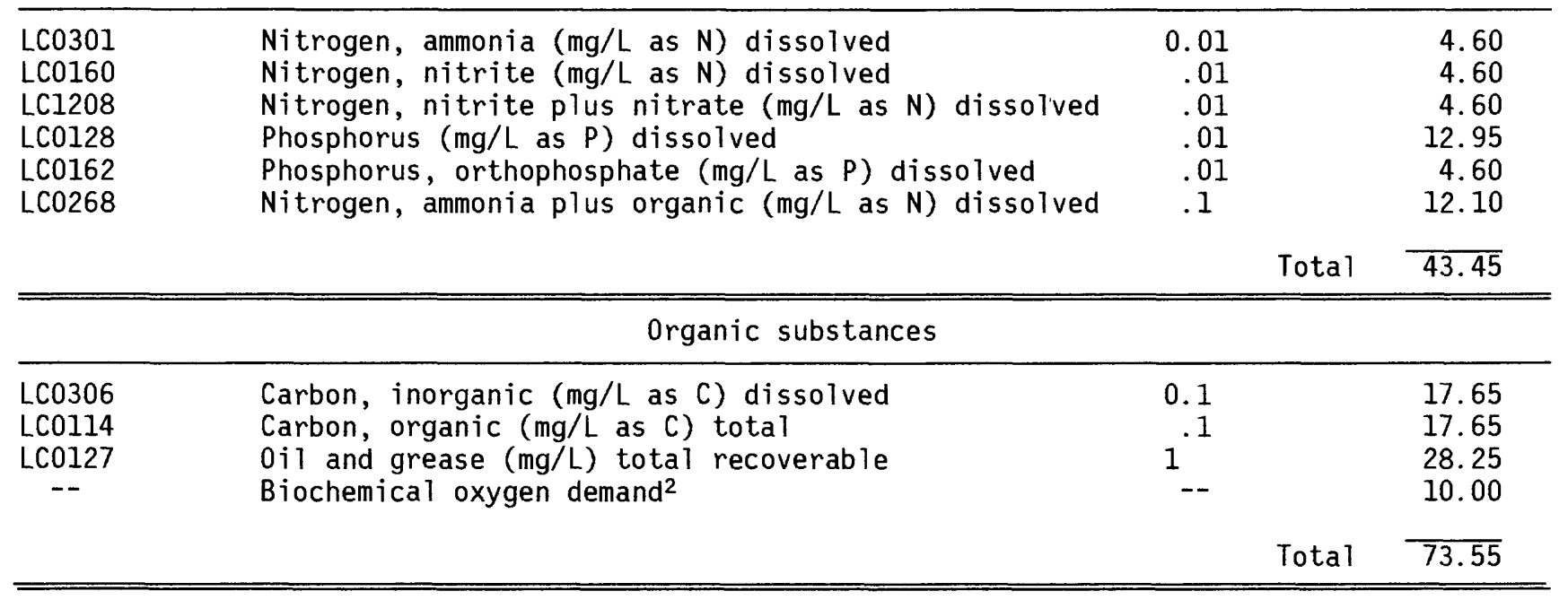

Priority pollutants

\begin{tabular}{llrr}
\hline SH1393 & Acid-extractable compounds $(\mu \mathrm{g} / \mathrm{L})$ total recoverable & $*$ & 189.40 \\
SH1394 & Base-extractable compounds $(\mu \mathrm{g} / \mathrm{L})$ total recoverable & $*$ & 221.50 \\
& & $\frac{410.90}{40 t a 1}$ & Tota \\
\hline \hline
\end{tabular}

\section{Pesticides}

\begin{tabular}{lllll}
\hline SH1304 & Chlorophenoxy acid herbicides $(\mu \mathrm{g} / \mathrm{L})$ total recoverable & 0.01 & 188.30 \\
SH1324 & Organochlorine insecticides with gross PCB and PCN & $* *$ & 113.40
\end{tabular}

$(\mu g / L)$ total recoverable

Total $\overline{301.70}$

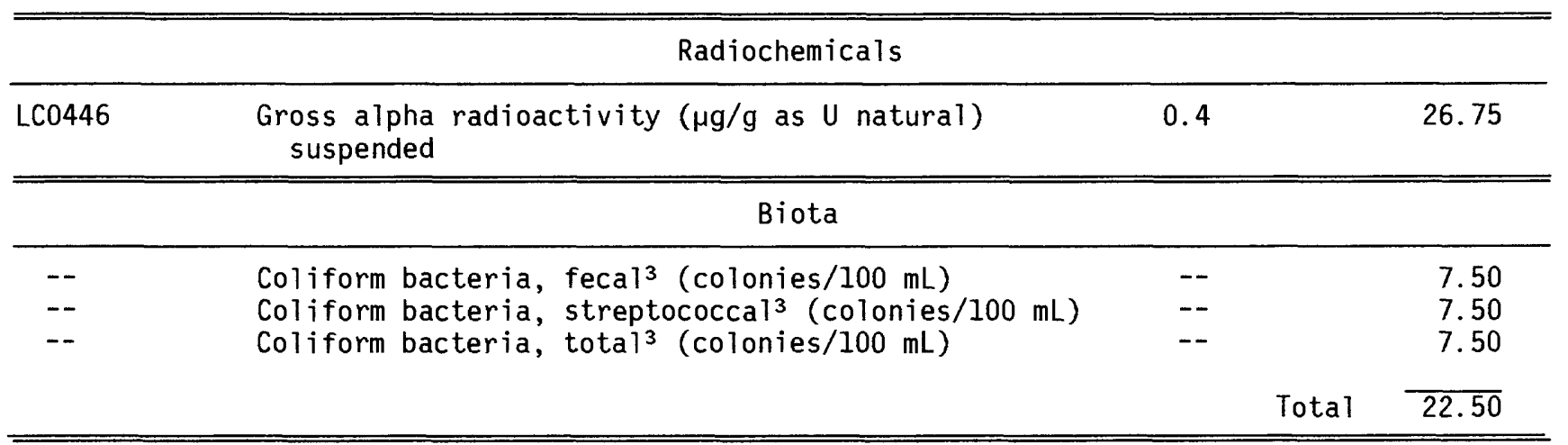

\begin{tabular}{llll}
\hline & Sediment \\
\hline-- & Suspended concentrations ${ }^{2}$ & -- & 5.00 \\
\hline
\end{tabular}

${ }^{1}$ Based on charges for similar metered measurements.

2 Trace-element cost factors differ between Colorado and Ohio because of differences in specific constituents most frequently analyzed.

${ }^{3}$ Based on charges by U.S. Geological Survey laboratory in Columbus, ohio. 
Table 10. Number of surface-water samples and estimated costs of: all measurements and analyses reported; those meeting either the ambient conditions or the data-availability criteria; and those meeting both screening criteria, by source of data, Colorado, 1984

[Cost estimates are based on 1984 U.S. Geological Survey laboratory costs]

\begin{tabular}{|c|c|c|c|c|c|c|c|c|}
\hline \multirow[b]{2}{*}{ Organizational category } & \multicolumn{2}{|c|}{ All samples } & \multicolumn{2}{|c|}{ Ambient conditions } & \multicolumn{2}{|c|}{ Data availability } & \multicolumn{2}{|c|}{$\begin{array}{l}\text { Total meeting } \\
\text { both criteria }\end{array}$} \\
\hline & $\begin{array}{l}\text { Number of } \\
\text { samples }\end{array}$ & $\begin{array}{l}\text { Estimated } \\
\text { cost } \\
\text { (thousands } \\
\text { of dollars) }\end{array}$ & $\begin{array}{l}\text { Number of } \\
\text { samples }\end{array}$ & $\begin{array}{l}\text { Estimated } \\
\text { cost } \\
\text { (thousands } \\
\text { of dollars) }\end{array}$ & $\begin{array}{l}\text { Number of } \\
\text { samples }\end{array}$ & $\begin{array}{l}\text { Estimated } \\
\text { cost } \\
\text { (thousands } \\
\text { of dollars) }\end{array}$ & $\begin{array}{l}\text { Number of } \\
\text { samples }\end{array}$ & $\begin{array}{c}\text { Estimated } \\
\text { cost } \\
\text { (thousands } \\
\text { of dollars) }\end{array}$ \\
\hline Federal: U.S. Geological Survey. & 18,080 & 446 & 18,080 & 446 & 18,080 & 446 & 18,080 & 446 \\
\hline $\begin{array}{l}\text { Other Department of the } \\
\text { Interior agencies. }\end{array}$ & 6,560 & 213 & 6,340 & 205 & 6,560 & 213 & 6,340 & 205 \\
\hline $\begin{array}{l}\text { U.S. Environmental } \\
\text { Protection Agency. }\end{array}$ & 830 & 96 & 0 & 0 & 180 & 7 & 0 & 0 \\
\hline Other Federal agencies. & 4,950 & 157 & 4,950 & 157 & 3,390 & 103 & 3,390 & 103 \\
\hline Total, Federal agencies. & 30,420 & 912 & 29,370 & 808 & 28,210 & 769 & 27,810 & 754 \\
\hline $\begin{array}{l}\text { Colorado Department of } \\
\text { Health. }\end{array}$ & 69,440 & 2,626 & 67,550 & 2,556 & 69,200 & 2,622 & 67,310 & 2,552 \\
\hline Other State agencies. & 3,640 & 145 & 3,640 & 145 & 3,640 & 145 & 3,640 & 145 \\
\hline Total, State agencies. & 73,080 & 2,771 & 71,190 & 2,701 & 72,840 & 2,767 & 70,950 & 2,697 \\
\hline Regional: Intrastate agencies. & 16,490 & 495 & 15,320 & 446 & 15,320 & 446 & 15,320 & 446 \\
\hline Local agencies. & 41,780 & 1,670 & 31,680 & 1,271 & 39,160 & 1,565 & 29,060 & 1,165 \\
\hline Academic institutions. & 2,730 & 101 & 2,730 & 101 & 2,330 & 90 & 2,330 & 90 \\
\hline Subtotals, all organizations. & 164,500 & 5,949 & 150,290 & 5,327 & 157,860 & 5,637 & 145,470 & 5,152 \\
\hline Subtotals, permit-required. & 143,620 & 5,159 & 0 & 0 & 71,390 & 1,794 & 0 & 0 \\
\hline Totals (rounded) & 308,120 & 11,110 & 150,290 & 5,330 & 229,250 & 7,431 & 145,470 & 5,152 \\
\hline
\end{tabular}


Table 11. Number of ground-water samples and estimated costs of: all measurements and analyses reported; those meeting either the ambient conditions or the data-availability criteria; and those meeting both screening criteria, by source of data, Colorado, 1984 [Cost estimates are based on 1984 U.S. Geological Survey laboratory costs]

\begin{tabular}{|c|c|c|c|c|c|c|c|c|}
\hline \multirow[b]{2}{*}{ Organizational category } & \multicolumn{2}{|c|}{ All samples } & \multicolumn{2}{|c|}{ Ambient conditions } & \multicolumn{2}{|c|}{ Data availability } & \multicolumn{2}{|c|}{$\begin{array}{l}\text { Total meeting } \\
\text { both criteria }\end{array}$} \\
\hline & $\begin{array}{l}\text { Number of } \\
\text { samples }\end{array}$ & $\begin{array}{l}\text { Estimated } \\
\text { cost } \\
\text { (thousands } \\
\text { of dollars) }\end{array}$ & $\begin{array}{l}\text { Number of } \\
\text { samples }\end{array}$ & $\begin{array}{l}\text { Estimated } \\
\text { cost } \\
\text { (thousands } \\
\text { of dollars) }\end{array}$ & $\begin{array}{l}\text { Number of } \\
\text { samples }\end{array}$ & $\begin{array}{l}\text { Estimated } \\
\text { cost } \\
\text { (thousands } \\
\text { of dollars) }\end{array}$ & $\begin{array}{l}\text { Number of } \\
\text { samples }\end{array}$ & $\begin{array}{l}\text { Estimated } \\
\text { cost } \\
\text { (thousands } \\
\text { of dollars) }\end{array}$ \\
\hline Federal: U.S. Geological Survey. & 1,880 & 84 & 1,880 & 84 & 1,880 & 84 & 1,880 & 84 \\
\hline $\begin{array}{l}\text { Other Department of the } \\
\text { Interior agencies. }\end{array}$ & 4,930 & 155 & 4,930 & 155 & 4,930 & 155 & 4,930 & 155 \\
\hline $\begin{array}{l}\text { U.S. Environmental } \\
\text { Protection Agency. }\end{array}$ & 1,530 & 224 & 20 & 4 & 0 & 0 & 0 & 0 \\
\hline Other Federal agencies. & 5,480 & 807 & 5,480 & 807 & 1,900 & 91 & 1,900 & 91 \\
\hline Total, Federal agencies. & 13,820 & 1,270 & 12,310 & 1,050 & 8,710 & 330 & 8,710 & 330 \\
\hline $\begin{array}{l}\text { Colorado Department of } \\
\text { Health. }\end{array}$ & 460 & 23 & 260 & 12 & 280 & 15 & 80 & 4 \\
\hline Other State agencies. & 0 & 0 & 0 & 0 & 0 & 0 & 0 & 0 \\
\hline Total, State agencies. & 460 & 23 & 260 & 12 & 280 & 15 & 80 & 4 \\
\hline Regional: Intrastate agencies. & 0 & 0 & 0 & 0 & 0 & 0 & 0 & 0 \\
\hline Local agencies. & 3,500 & 158 & 3,450 & 156 & 3,380 & 143 & 3,330 & 141 \\
\hline Academic institutions. & 190 & 6 & 190 & 6 & 190 & 6 & 190 & 6 \\
\hline Subtotals, all organizations. & 17,970 & 1,457 & 16,210 & 1,224 & 12,560 & 494 & 12,310 & 481 \\
\hline Subtotals, permit-required. & 12,110 & 919 & 0 & 0 & 13,110 & 919 & 0 & 0 \\
\hline Totals (rounded) & 30,080 & 2,380 & 16,210 & 1,220 & 25,670 & 1,410 & 12,310 & 480 \\
\hline
\end{tabular}


Table 12. Number of surface-water samples and estimated costs of: those meeting both the ambient conditions and the dataavailability criteria and either the location, quality assurance, or the computerized criteria; and those meeting all five, by source of data, Colorado, 1984

[Cost estimates are based on 1984 U.S. Geological Survey laboratory costs]

\begin{tabular}{|c|c|c|c|c|c|c|c|c|}
\hline \multirow[b]{2}{*}{ Organizational category } & \multicolumn{2}{|c|}{ Location } & \multicolumn{2}{|c|}{ Quality assurance } & \multicolumn{2}{|c|}{ Computerized } & \multicolumn{2}{|c|}{$\begin{array}{l}\text { Total meeting } \\
\text { all criteria }\end{array}$} \\
\hline & $\begin{array}{l}\text { Number of } \\
\text { samples }\end{array}$ & $\begin{array}{l}\text { Estimated } \\
\text { cost } \\
\text { (thousands } \\
\text { of dollars) }\end{array}$ & $\begin{array}{l}\text { Number of } \\
\text { samples }\end{array}$ & $\begin{array}{l}\text { Estimated } \\
\text { cost } \\
\text { (thousands } \\
\text { of dollars) }\end{array}$ & $\begin{array}{l}\text { Number of } \\
\text { samples }\end{array}$ & $\begin{array}{l}\text { Estimated } \\
\text { cost } \\
\text { (thousands } \\
\text { of dollars) }\end{array}$ & $\begin{array}{l}\text { Number of } \\
\text { samples }\end{array}$ & $\begin{array}{l}\text { Estimated } \\
\text { cost } \\
\text { (thousands } \\
\text { of dollars) }\end{array}$ \\
\hline U.S. Geological Survey. & 17,900 & 444 & 17,900 & 444 & 17,270 & 401 & 17,270 & 401 \\
\hline $\begin{array}{l}\text { Other Department of the } \\
\text { Interior agencies. }\end{array}$ & 6,060 & 196 & 6,340 & 205 & 5,270 & 179 & 5,270 & 176 \\
\hline $\begin{array}{l}\text { U.S. Environmental } \\
\text { Protection Agency. }\end{array}$ & 0 & 0 & 0 & 0 & 0 & 0 & 0 & 0 \\
\hline Other Federal agencies. & 3,290 & 74 & 2,540 & 88 & 1,160 & 67 & 1,160 & 67 \\
\hline Total, Federal agencies. & 27,250 & 714 & 26,780 & 737 & 23,700 & 647 & 23,700 & 644 \\
\hline $\begin{array}{l}\text { Colorado Department of } \\
\text { Health. }\end{array}$ & 65,860 & 2,527 & 67,600 & 2,582 & 62,660 & 2,455 & 62,610 & 2,452 \\
\hline Other State agencies. & 3,640 & 145 & 3,340 & 139 & 160 & 7 & 0 & 0 \\
\hline Total, State agencies. & 69,500 & 2,672 & 70,940 & 2,721 & 62,820 & 2,462 & 62,610 & 2,452 \\
\hline Regional: Intrastate agencies. & 15,010 & 436 & 15,220 & 441 & 15,200 & 441 & 15,010 & 436 \\
\hline Local agencies. & 16,190 & 628 & 26,350 & 1,110 & 6,060 & 454 & 3,380 & 214 \\
\hline Academic institutions. & 2,010 & 83 & 2,330 & 90 & 1,430 & 59 & 1,140 & 56 \\
\hline Subtotals, all organizations. & 129,960 & 4,533 & 141,620 & 5,099 & 109,210 & 4,063 & 105,840 & 3,802 \\
\hline Subtotals, permit-required. & 0 & 0 & 0 & 0 & 0 & 0 & 0 & 0 \\
\hline Totals (rounded) & 129,960 & 4,530 & 141,620 & 5,100 & 109,210 & 4,060 & 105,840 & 3,800 \\
\hline
\end{tabular}


Table 13. Number of ground-water samples and estimated costs of: those meeting both the ambient conditions and the dataavailability criteria and either the location, quality assurance, or the computerized criteria; and those meeting all five, by source of data, Colorado, 1984

[Cost estimates are based on 1984 U.S. Geological Survey laboratory costs]

\begin{tabular}{|c|c|c|c|c|c|c|c|c|}
\hline \multirow[b]{2}{*}{ Organizational category } & \multicolumn{2}{|c|}{ Location } & \multicolumn{2}{|c|}{ Quality assurance } & \multicolumn{2}{|c|}{ Computerized } & \multicolumn{2}{|c|}{$\begin{array}{l}\text { Total meeting } \\
\text { all criteria }\end{array}$} \\
\hline & $\begin{array}{l}\text { Number of } \\
\text { samples }\end{array}$ & $\begin{array}{l}\text { Estimated } \\
\text { cost } \\
\text { (thousands } \\
\text { of dollars) }\end{array}$ & $\begin{array}{l}\text { Number of } \\
\text { samples }\end{array}$ & $\begin{array}{l}\text { Estimated } \\
\text { cost } \\
\text { (thousands } \\
\text { of dollars) }\end{array}$ & $\begin{array}{l}\text { Number of } \\
\text { samples }\end{array}$ & $\begin{array}{l}\text { Estimated } \\
\text { cost } \\
\text { (thousands } \\
\text { of dollars) }\end{array}$ & $\begin{array}{l}\text { Number of } \\
\text { samples }\end{array}$ & $\begin{array}{l}\text { Estimated } \\
\text { cost } \\
\text { (thousands } \\
\text { of dollars) }\end{array}$ \\
\hline Federal: U.S. Geological Survey. & 1,880 & 84 & 1,880 & 84 & 1,640 & 74 & 1,640 & 74 \\
\hline $\begin{array}{l}\text { 0ther Department of the } \\
\text { Interior agencies. }\end{array}$ & 4,880 & 156 & 4,880 & 156 & 4,880 & 156 & 4,880 & 156 \\
\hline $\begin{array}{l}\text { U.S. Environmental } \\
\text { Protection Agency. }\end{array}$ & 0 & 0 & 0 & 0 & 0 & 0 & 0 & 0 \\
\hline Other Federal agencies. & 1,850 & 82 & 1,850 & 82 & 1,850 & 82 & 1,850 & 82 \\
\hline Total, Federal agencies. & 8,610 & 322 & 8,610 & 322 & 8,370 & 312 & 8,370 & 312 \\
\hline $\begin{array}{l}\text { Colorado Department of } \\
\text { Health. }\end{array}$ & 0 & 0 & 80 & 4 & 0 & 0 & 0 & 0 \\
\hline 0ther State agencies. & 0 & 0 & 0 & 0 & 0 & 0 & 0 & 0 \\
\hline Total, State agencies. & 0 & 0 & 80 & 4 & 0 & 0 & 0 & 0 \\
\hline Regional: Intrastate agencies. & 0 & 0 & 0 & 0 & 0 & 0 & 0 & 0 \\
\hline Local agencies. & 1,180 & 52 & 3,100 & 318 & 70 & 3 & 70 & 3 \\
\hline Academic institutions. & 190 & 6 & 190 & 6 & 0 & 0 & 0 & 0 \\
\hline Subtotals, all organizations. & 9,980 & 380 & 11,980 & 650 & 8,440 & 315 & 8,440 & 315 \\
\hline Subtotals, permit-required. & 0 & 0 & 0 & 0 & 0 & 0 & 0 & 0 \\
\hline Totals (rounded) & 9,980 & 380 & 11,980 & 650 & 8,440 & 320 & 8,440 & 320 \\
\hline
\end{tabular}


Table 14. Estimated surface-water-quality laboratory costs of ambient and compliance-and-enforcement programs, after screening, for physical properties and major-constituent groups, Colorado, 1984

[All costs are reported in thousands of dollars; cost estimates are based on 1984 U.S. Geological Survey laboratory costs]

\begin{tabular}{|c|c|c|c|c|c|c|c|c|c|c|c|c|}
\hline \multirow[b]{2}{*}{$\begin{array}{l}\text { Source of } \\
\text { data }\end{array}$} & \multirow[b]{2}{*}{$\begin{array}{l}\text { Physical } \\
\text { properties }\end{array}$} & \multicolumn{11}{|c|}{ Constituent group } \\
\hline & & $\begin{array}{l}\text { Inorganic } \\
\text { constituents }\end{array}$ & $\begin{array}{l}\text { Trace } \\
\text { elements }\end{array}$ & $\begin{array}{l}\text { Major } \\
\text { metals }\end{array}$ & Nutrients & $\begin{array}{l}\text { Organic } \\
\text { substances }\end{array}$ & $\begin{array}{l}\text { Priority } \\
\text { pollutants }\end{array}$ & Pesticides & $\begin{array}{l}\text { Radio- } \\
\text { chemicals }\end{array}$ & Biota & Sediment & Total \\
\hline \multicolumn{13}{|l|}{ Federal: } \\
\hline $\begin{array}{l}\text { U.S. Geologica } 1 \\
\text { Survey. }\end{array}$ & 139 & 72 & 62 & 5 & 73 & 16 & 7 & 2 & 2 & 15 & 8 & 401 \\
\hline $\begin{array}{l}\text { Other Department } \\
\text { of the Interior } \\
\text { agencies. }\end{array}$ & 31 & 107 & 15 & 1 & 5 & 14 & 0 & 0 & 0 & 3 & 0 & 176 \\
\hline $\begin{array}{l}\text { U. S. Environmental } \\
\text { Protection Agency. }\end{array}$ & 0 & 0 & 0 & 0 & 0 & 0 & 0 & 0 & 0 & 0 & 0 & 0 \\
\hline other Federal & 2 & 6 & 10 & 1 & 3 & 3 & 23 & 17 & 0 & 0 & 2 & 67 \\
\hline $\begin{array}{l}\text { Total, Federal } \\
\text { agencies. }\end{array}$ & 172 & 185 & 87 & 7 & 81 & 33 & 30 & 19 & 2 & 18 & 10 & 644 \\
\hline \multicolumn{13}{|l|}{ State: } \\
\hline $\begin{array}{l}\text { Colorado } \\
\text { Department } \\
\text { of Health }\end{array}$ & 222 & 827 & 402 & 31 & 490 & 375 & 0 & 0 & 1 & 104 & 0 & 2,452 \\
\hline other State & 0 & 0 & 0 & 0 & 0 & 0 & 0 & 0 & 0 & 0 & 0 & 0 \\
\hline $\begin{array}{l}\text { Total, State } \\
\text { agencies. }\end{array}$ & 222 & 827 & 402 & 31 & 490 & 375 & 0 & 0 & 1 & 104 & 0 & 2,452 \\
\hline $\begin{array}{l}\text { Regional: Intra- } \\
\text { state agencies. }\end{array}$ & 80 & 178 & 50 & 5 & 23 & 23 & 0 & 0 & 0 & 77 & 0 & 436 \\
\hline Local agencies. & 0 & 31 & 50 & 2 & 20 & 31 & 59 & 0 & 0 & 21 & 0 & 214 \\
\hline $\begin{array}{l}\text { Academic } \\
\quad \text { institutions. }\end{array}$ & 5 & 17 & 34 & 0 & 0 & 0 & 0 & 0 & 0 & 0 & 0 & 56 \\
\hline $\begin{array}{l}\text { Total (rounded), } \\
\text { all organization }\end{array}$ & ns. 480 & 1,240 & 620 & 40 & 610 & 460 & 90 & 20 & 3 & 220 & 10 & 3,800 \\
\hline
\end{tabular}


Table 15. Estimated ground-water-quality laboratory costs of ambient and compliance-and-enforcement programs after screening, for physical properties and major-constituent groups, Colorado, 1984

[All costs are reported in thousands of dollars; cost estimates are based on 1984 U.S. Geological Survey laboratory costs]

\begin{tabular}{|c|c|c|c|c|c|c|c|c|c|c|c|}
\hline \multirow[b]{2}{*}{$\begin{array}{c}\text { Source of } \\
\text { data }\end{array}$} & \multirow[b]{2}{*}{$\begin{array}{l}\text { Physical } \\
\text { properties }\end{array}$} & \multicolumn{10}{|c|}{ Constituent group } \\
\hline & & $\begin{array}{l}\text { Inorganic } \\
\text { constituents }\end{array}$ & $\begin{array}{l}\text { Trace } \\
\text { elements }\end{array}$ & $\begin{array}{l}\text { Major } \\
\text { metals }\end{array}$ & Nutrients & $\begin{array}{l}\text { Organic } \\
\text { substances }\end{array}$ & $\begin{array}{l}\text { Priority } \\
\text { pollutants }\end{array}$ & Pesticides & $\begin{array}{l}\text { Radio- } \\
\text { chemicals }\end{array}$ & Biota & Total \\
\hline \multicolumn{12}{|l|}{ Federal: } \\
\hline $\begin{array}{l}\text { U.S. Geological } \\
\text { Survey. }\end{array}$ & 4 & 13 & 23 & 2 & 12 & 8 & 8 & 0 & 1 & 3 & 74 \\
\hline $\begin{array}{l}\text { Other Department } \\
\text { of the Interior } \\
\text { agencies. }\end{array}$ & 38 & 51 & 30 & 3 & 7 & 12 & 4 & 11 & 0 & 0 & 156 \\
\hline $\begin{array}{l}\text { U.S. Environmental } \\
\text { Protection Agency }\end{array}$ & $y$. & 0 & 0 & 0 & 0 & 0 & 0 & 0 & 0 & 0 & 0 \\
\hline Other Federal & 3 & 52 & 20 & 2 & 0 & 3 & 0 & 0 & 2 & 0 & 82 \\
\hline $\begin{array}{l}\text { Total, Federal } \\
\text { agencies. }\end{array}$ & 45 & 116 & 73 & 7 & 19 & 23 & 12 & 11 & 3 & 3 & 312 \\
\hline
\end{tabular}

State:

\begin{tabular}{|c|c|c|c|c|c|c|c|c|c|c|c|}
\hline $\begin{array}{l}\text { Colorado } \\
\text { Department } \\
\text { of Health }\end{array}$ & 0 & 0 & 0 & 0 & 0 & 0 & 0 & 0 & 0 & 0 & 0 \\
\hline Other State & 0 & 0 & 0 & 0 & 0 & 0 & 0 & 0 & 0 & 0 & 0 \\
\hline $\begin{array}{l}\text { Total, State } \\
\text { agencies. }\end{array}$ & 0 & 0 & 0 & 0 & 0 & 0 & 0 & 0 & 0 & 0 & 0 \\
\hline $\begin{array}{l}\text { Regiona } 1: \text { Intra- } \\
\text { state agencies. }\end{array}$ & 0 & 0 & 0 & 0 & 0 & 0 & 0 & 0 & 0 & 0 & 0 \\
\hline Local agencies. & 0 & 1 & 1 & 0 & 0 & 0 & 0 & 0 & 0 & 0 & 3 \\
\hline $\begin{array}{l}\text { Academic } \\
\text { institutions. }\end{array}$ & 0 & 0 & 0 & 0 & 0 & 0 & 0 & 0 & 0 & 0 & 0 \\
\hline $\begin{array}{l}\text { Total (rounded), } \\
\text { all organizations. }\end{array}$ & 40 & 120 & 70 & 10 & 20 & 20 & 10 & 10 & 3 & 3 & 320 \\
\hline
\end{tabular}


Table 16. Number of surface-water samples and estimated costs of: all measurements and analyses reported; those meeting either the ambient conditions or the data-availability criteria; and those meeting both screening criteria, by source of data, Ohio, 1984 [Cost estimates are based on 1984 U.S. Geological Survey laboratory costs]

\begin{tabular}{|c|c|c|c|c|c|c|c|c|}
\hline \multirow[b]{2}{*}{ Organizational category } & \multicolumn{2}{|c|}{ A11 samples } & \multicolumn{2}{|c|}{ Ambient conditions } & \multicolumn{2}{|c|}{ Data availability } & \multicolumn{2}{|c|}{$\begin{array}{l}\text { Total meeting } \\
\text { both criteria }\end{array}$} \\
\hline & $\begin{array}{l}\text { Number of } \\
\text { samples }\end{array}$ & $\begin{array}{l}\text { Estimated } \\
\text { cost } \\
\text { (thousands } \\
\text { of dollars) }\end{array}$ & $\begin{array}{l}\text { Number of } \\
\text { samples }\end{array}$ & $\begin{array}{l}\text { Estimated } \\
\text { cost } \\
\text { (thousands } \\
\text { of dollars) }\end{array}$ & $\begin{array}{l}\text { Number of } \\
\text { samples }\end{array}$ & $\begin{array}{l}\text { Estimated } \\
\text { cost } \\
\text { (thousands } \\
\text { of dollars) }\end{array}$ & $\begin{array}{l}\text { Number of } \\
\text { samples }\end{array}$ & $\begin{array}{l}\text { Estimated } \\
\text { cost } \\
\text { (thousands } \\
\text { of dollars) }\end{array}$ \\
\hline Federal: U.S. Geological Survey. & 7,740 & 133 & 7,740 & 133 & 7,740 & 133 & 7,740 & 133 \\
\hline $\begin{array}{l}\text { 0ther Department of the } \\
\text { Interior agencies. }\end{array}$ & 80 & 2 & 60 & 1 & 80 & 2 & 60 & 1 \\
\hline $\begin{array}{l}\text { U. S. Environmental } \\
\text { Protection Agency. }\end{array}$ & 100 & 5 & 0 & 0 & 0 & 0 & 0 & 0 \\
\hline Other Federal agencies. & 3,440 & 152 & 3,440 & 152 & 3,320 & 146 & 3,320 & 146 \\
\hline Total, Federal agencies. & 11,360 & 292 & 11,240 & 286 & 11,140 & 281 & 11,120 & 280 \\
\hline $\begin{array}{l}\text { Ohio Environmental } \\
\text { Protection Agency. }\end{array}$ & 33,680 & 1,870 & 31,790 & 1,673 & 31,720 & 1,621 & 29,830 & 1,425 \\
\hline other State agencies. & 3,970 & 129 & 3,070 & 120 & 3,970 & 129 & 2,770 & 106 \\
\hline Tota1, State agencies. & 37,650 & 2,000 & 34,860 & 1,793 & 35,690 & 1,750 & 32,600 & 1,531 \\
\hline Regional: Interstate agencies. & 4,000 & 385 & 4,000 & 385 & 4,000 & 385 & 4,000 & 385 \\
\hline Local agencies. & 78,590 & 5,407 & 78,590 & 5,407 & 43,650 & 1,596 & 43,650 & 1,596 \\
\hline Academic institutions. & 12,930 & 1,084 & 12,910 & 1,079 & 11,190 & 1,032 & 11,190 & 1,032 \\
\hline Subtotals, all organizations. & 144,530 & 9,168 & 141,600 & 8,950 & 105,670 & 5,044 & 102,560 & 4,824 \\
\hline Subtotals, permit-required. & $1,002,300$ & 35,431 & 0 & 0 & $1,002,300$ & 35,431 & 0 & 0 \\
\hline Totals (rounded) & $1,146,830$ & 44,600 & 141,600 & 8,950 & $1,107,970$ & 40,470 & 102,560 & 4,820 \\
\hline
\end{tabular}


Table 17. Number of ground-water samples and estimated costs of: all measurements and analyses reported; those meeting either the ambient conditions or the data-availability criteria; and those meeting both screening criteria, by source of data, Ohio, 1984 [Cost estimates are based on 1984 U.S. Geological Survey laboratory costs]

\begin{tabular}{|c|c|c|c|c|c|c|c|c|}
\hline \multirow[b]{2}{*}{ Organizational category } & \multicolumn{2}{|c|}{ All samples } & \multicolumn{2}{|c|}{ Ambient conditions } & \multicolumn{2}{|c|}{ Data availability } & \multicolumn{2}{|c|}{$\begin{array}{l}\text { Total meeting } \\
\text { both criteria }\end{array}$} \\
\hline & $\begin{array}{l}\text { Number of } \\
\text { samples }\end{array}$ & $\begin{array}{l}\text { Estimated } \\
\text { cost } \\
\text { (thousands } \\
\text { of dollars) }\end{array}$ & $\begin{array}{l}\text { Number of } \\
\text { samples }\end{array}$ & $\begin{array}{l}\text { Estimated } \\
\text { cost } \\
\text { (thousands } \\
\text { of dollars) }\end{array}$ & $\begin{array}{l}\text { Number of } \\
\text { samples }\end{array}$ & $\begin{array}{l}\text { Estimated } \\
\text { cost } \\
\text { (thousands } \\
\text { of dollars) }\end{array}$ & $\begin{array}{l}\text { Number of } \\
\text { samples }\end{array}$ & $\begin{array}{l}\text { Estimated } \\
\text { cost } \\
\text { (thousands } \\
\text { of dollars) }\end{array}$ \\
\hline Federal: U.S. Geological Survey. & 670 & 45 & 670 & 45 & 670 & 45 & 670 & 45 \\
\hline $\begin{array}{l}\text { Other Department of the } \\
\text { Interior agencies. }\end{array}$ & 40 & 1 & 0 & 0 & 40 & 1 & 0 & 0 \\
\hline $\begin{array}{l}\text { U.S. Environmental } \\
\text { Protection Agency. }\end{array}$ & 140 & 6 & 140 & 6 & 0 & 0 & 0 & 0 \\
\hline Other Federal agencies. & 140 & 10 & 120 & 5 & 70 & 2 & 70 & 2 \\
\hline Total, Federal agencies. & 990 & 62 & 930 & 56 & 780 & 48 & 740 & 47 \\
\hline $\begin{array}{l}\text { Ohio Environmental } \\
\text { Protection Agency. }\end{array}$ & 3,390 & 344 & 1,150 & 58 & 3,390 & 344 & 1,150 & 58 \\
\hline Other State agencies. & 9,670 & 218 & 9,670 & 218 & 9,670 & 218 & 9,670 & 218 \\
\hline Total, State agencies. & 13,060 & 562 & 10,820 & 276 & 13,060 & 562 & 10,820 & 276 \\
\hline Regiona1: Interstate agencies. & 0 & 0 & 0 & 0 & 0 & 0 & 0 & 0 \\
\hline Local agencies. & 33,830 & 4,088 & 33,830 & 4,088 & 12,830 & 495 & 12,830 & 495 \\
\hline Academic institutions. & 150 & 7 & 140 & 3 & 0 & 0 & 0 & 0 \\
\hline Subtotals, all organizations. & 48,030 & 4,719 & 45,720 & 4,423 & 26,670 & 1,105 & 24,390 & 818 \\
\hline Subtotals, permit-required. & 2,690 & 268 & 0 & 0 & 2,670 & 268 & 0 & 0 \\
\hline Totals (rounded) & 50,700 & 4,980 & 45,720 & 4,420 & 29,340 & 1,370 & 24,390 & 820 \\
\hline
\end{tabular}


Table 18. Number of surface-water samples and estimated costs of: those meeting both the ambient conditions and the dataavailability criteria and either the location, quality assurance or the computerized criteria; and those meeting all five, by source of data, Ohio, 1984

[Cost estimates are based on 1984 U.S. Geological Survey laboratory costs]

\begin{tabular}{|c|c|c|c|c|c|c|c|c|}
\hline \multirow[b]{2}{*}{ Organizational category } & \multicolumn{2}{|c|}{ Location } & \multicolumn{2}{|c|}{ Quality assurance } & \multicolumn{2}{|c|}{ Computerized } & \multicolumn{2}{|c|}{$\begin{array}{l}\text { Total meeting } \\
\text { all criteria }\end{array}$} \\
\hline & $\begin{array}{l}\text { Number of } \\
\text { samples }\end{array}$ & $\begin{array}{l}\text { Estimated } \\
\text { cost } \\
\text { (thousands } \\
\text { of dollars) }\end{array}$ & $\begin{array}{l}\text { Number of } \\
\text { samples }\end{array}$ & $\begin{array}{l}\text { Estimated } \\
\text { cost } \\
\text { (thousands } \\
\text { of dollars) }\end{array}$ & $\begin{array}{l}\text { Number of } \\
\text { samples }\end{array}$ & $\begin{array}{l}\text { Estimated } \\
\text { cost } \\
\text { (thousands } \\
\text { of dollars) }\end{array}$ & $\begin{array}{l}\text { Number of } \\
\text { samples }\end{array}$ & $\begin{array}{l}\text { Estimated } \\
\text { cost } \\
\text { (thousands } \\
\text { of dollars) }\end{array}$ \\
\hline Federal: U.S. Geological Survey. & 7,740 & 133 & 7,740 & 133 & 7,740 & 133 & 7,740 & 133 \\
\hline $\begin{array}{l}\text { Other Department of the } \\
\text { Interior agencies. }\end{array}$ & 60 & 1 & 60 & 1 & 60 & 1 & 60 & 1 \\
\hline $\begin{array}{l}\text { U.S. Environmental } \\
\text { Protection Agency. }\end{array}$ & 0 & 0 & 0 & 0 & 0 & 0 & 0 & 0 \\
\hline Other Federal agencies. & 3,320 & 146 & 3,320 & 146 & 3,270 & 144 & 3,270 & 144 \\
\hline Total, Federal agencies. & 11,120 & 280 & 11,120 & 280 & 11,070 & 278 & 11,070 & 278 \\
\hline $\begin{array}{l}\text { Ohio Environmental } \\
\text { Protection Agency. }\end{array}$ & 29,530 & 1,417 & 29,830 & 1,425 & 29,530 & 1,417 & 29,530 & 1,417 \\
\hline other State agencies. & 2,770 & 106 & 2,670 & 102 & 0 & 0 & 0 & 0 \\
\hline Total, State agencies. & 32,300 & 1,523 & 32,500 & 1,527 & 29,530 & 1,417 & 29,530 & 1,417 \\
\hline Regional: Interstate agencies. & 4,000 & 385 & 4,000 & 385 & 4,000 & 385 & 4,000 & 385 \\
\hline Local agencies. & 43,640 & 1,595 & 43,600 & 1,595 & 2,080 & 83 & 2,080 & 83 \\
\hline Academic institutions. & 11,190 & 1,032 & 11,190 & 1,032 & 9,600 & 817 & 9,600 & 817 \\
\hline Subtotals, all organizations. & 102,250 & 4,815 & 102,410 & 4,819 & 56,280 & 2,980 & 56,280 & 2,980 \\
\hline Subtotals, permit-required. & 0 & 0 & 0 & 0 & 0 & 0 & 0 & 0 \\
\hline Totals (rounded) & 102,250 & 4,820 & 102,410 & 4,820 & 56,280 & 2,980 & 56,280 & 2,980 \\
\hline
\end{tabular}


Table 19. Number of ground-water samples and estimated costs of: those meeting both the ambient conditions and the dataavailability criteria and either the location, quality assurance, or the computerized criteria; and those meeting all five, by source of data, Ohio, 1984

[Cost estimates are based on 1984 U.S. Geological Survey laboratory costs]

\begin{tabular}{|c|c|c|c|c|c|c|c|c|}
\hline \multirow[b]{2}{*}{ Organizational category } & \multicolumn{2}{|c|}{ Location } & \multicolumn{2}{|c|}{ Quality assurance } & \multicolumn{2}{|c|}{ Computerized } & \multicolumn{2}{|c|}{$\begin{array}{l}\text { Total meeting } \\
\text { all criteria }\end{array}$} \\
\hline & $\begin{array}{l}\text { Number of } \\
\text { samples }\end{array}$ & $\begin{array}{l}\text { Estimated } \\
\text { cost } \\
\text { (thousands } \\
\text { of dollars) }\end{array}$ & $\begin{array}{l}\text { Number of } \\
\text { samples }\end{array}$ & $\begin{array}{l}\text { Estimated } \\
\text { cost } \\
\text { (thousands } \\
\text { of dollars) }\end{array}$ & $\begin{array}{l}\text { Number of } \\
\text { samples }\end{array}$ & $\begin{array}{l}\text { Estimated } \\
\text { cost } \\
\text { (thousands } \\
\text { of dollars) }\end{array}$ & $\begin{array}{l}\text { Number of } \\
\text { samples }\end{array}$ & $\begin{array}{c}\text { Estimated } \\
\text { cost } \\
\text { (thousands } \\
\text { of dollars) }\end{array}$ \\
\hline Federal: U.S. Geological Survey. & 670 & 45 & 670 & 45 & 670 & 45 & 670 & 45 \\
\hline $\begin{array}{l}\text { Other Department of the } \\
\text { Interior agencies. }\end{array}$ & 0 & 0 & 0 & 0 & 0 & 0 & 0 & 0 \\
\hline $\begin{array}{l}\text { U.S. Environmental } \\
\text { Protection Agency. }\end{array}$ & 0 & 0 & 0 & 0 & 0 & 0 & 0 & 0 \\
\hline Other Federal agencies. & 70 & 2 & 70 & 2 & 0 & 0 & 0 & 0 \\
\hline Total, Federal agencies. & 740 & 47 & 740 & 47 & 670 & 45 & 670 & 45 \\
\hline $\begin{array}{l}\text { State: } \\
\quad \text { Protection Agency. }\end{array}$ & 1,150 & 58 & 1,150 & 58 & 0 & 0 & 0 & 0 \\
\hline Other State agencies. & 810 & 18 & 9,670 & 218 & 0 & 0 & 0 & 0 \\
\hline Total, State agencies. & 1,960 & 76 & 10,820 & 276 & 0 & 0 & 0 & 0 \\
\hline Regional: Interstate agencies. & 0 & 0 & 0 & 0 & 0 & 0 & 0 & 0 \\
\hline Local agencies. & 12,830 & 495 & 12,830 & 495 & 0 & 0 & 0 & 0 \\
\hline Academic institutions. & 0 & 0 & 0 & 0 & 0 & 0 & 0 & 0 \\
\hline Subtotals, all organizations. & 15,530 & 618 & 24,390 & 818 & 670 & 45 & 670 & 45 \\
\hline Subtotals, permit-required & 0 & 0 & 0 & 0 & 0 & 0 & 0 & 0 \\
\hline Totals (rounded) & 15,530 & 620 & 24,390 & 820 & 670 & 40 & 670 & 40 \\
\hline
\end{tabular}


Table 20. Estimated surface-water-quality laboratory costs for ambient and compliance-and-enforcement programs, after screening, for physical properties and major-constituent groups, Ohio, 1984

[All costs are reported in thousands of dollars; cost estimates are based on 1984 U.S. Geological Survey laboratory costs]

\begin{tabular}{|c|c|c|c|c|c|c|c|c|c|c|c|c|}
\hline \multirow[b]{2}{*}{$\begin{array}{l}\text { Source of } \\
\text { data }\end{array}$} & \multirow[b]{2}{*}{$\begin{array}{l}\text { Physical } \\
\text { properties }\end{array}$} & \multicolumn{10}{|c|}{ Constituent group } & \multirow[b]{2}{*}{ Total } \\
\hline & & $\begin{array}{l}\text { Inorganic } \\
\text { constituents }\end{array}$ & $\begin{array}{l}\text { Trace } \\
\text { elements }\end{array}$ & $\begin{array}{l}\text { Major } \\
\text { metals }\end{array}$ & Nutrients & $\begin{array}{c}\text { Organic } \\
\text { substances }\end{array}$ & $\begin{array}{l}\text { Priority } \\
\text { pollutants }\end{array}$ & Pesticides & $\begin{array}{l}\text { Radio- } \\
\text { chemicals }\end{array}$ & Biota & Sediment & \\
\hline \multicolumn{13}{|l|}{ Federal: } \\
\hline $\begin{array}{l}\text { U.S. Geological } \\
\text { Survey. }\end{array}$ & 52 & 11 & 25 & 2 & 8 & 8 & 11 & 0 & 0 & 2 & 14 & 133 \\
\hline $\begin{array}{l}\text { Other Department } \\
\text { of the Interior } \\
\text { agencies. }\end{array}$ & 0 & 0 & 0 & 0 & 0 & 0 & 0 & 0 & 0 & 1 & 0 & 1 \\
\hline $\begin{array}{l}\text { U.S. Environmental } \\
\text { Protection Agency. }\end{array}$ & . & 0 & 0 & 0 & 0 & 0 & 0 & 0 & 0 & 0 & 0 & 0 \\
\hline Other Federal & 10 & 34 & 70 & 5 & 20 & 0 & 0 & 0 & 0 & 4 & 0 & 144 \\
\hline $\begin{array}{l}\text { Total, Federal } \\
\text { agencies. }\end{array}$ & 62 & 45 & 95 & 7 & 28 & 8 & 11 & 0 & 0 & 7 & 14 & 278 \\
\hline \multicolumn{13}{|l|}{ State: } \\
\hline $\begin{array}{l}\text { Ohio Environmental } \\
\text { Protection Agency. }\end{array}$ & 66 & 186 & 489 & 24 & 223 & 208 & 123 & 0 & 0 & 88 & 9 & 1,417 \\
\hline $\begin{array}{c}\text { Other State } \\
\text { agencies. }\end{array}$ & 0 & 0 & 0 & 0 & 0 & 0 & 0 & 0 & 0 & 0 & 0 & 0 \\
\hline $\begin{array}{l}\text { Total, State } \\
\text { agencies. }\end{array}$ & 66 & 186 & 489 & 24 & 223 & 208 & 123 & 0 & 0 & 88 & 9 & 1,417 \\
\hline $\begin{array}{l}\text { Regional: Inter- } \\
\text { state agencies. }\end{array}$ & 32 & 8 & 22 & 2 & 6 & 10 & 303 & 0 & 0 & 3 & 0 & 385 \\
\hline Local agencies. & 6 & 20 & 0 & 0 & 18 & 31 & 0 & 0 & 0 & 9 & 0 & 83 \\
\hline $\begin{array}{l}\text { Academic } \\
\text { institutions. }\end{array}$ & 0 & 113 & 0 & 0 & 104 & 44 & 0 & 543 & 0 & 0 & 12 & 817 \\
\hline $\begin{array}{l}\text { Total (rounded), } \\
\text { all organization }\end{array}$ & ns. 170 & 37 & 610 & 30 & 380 & 300 & 440 & 540 & 0 & 110 & 40 & 2,980 \\
\hline
\end{tabular}


Table 21. Estimated ground-water-quality laboratory costs for ambient and compliance-and-enforcement programs, after screening, for physical properties and major-constituent groups, Ohio, 1984

[All costs are reported in thousands of dollars; cost estimates are based on 1984 U.S. Geological Survey laboratory costs]

\begin{tabular}{|c|c|c|c|c|c|c|c|c|c|c|c|}
\hline \multirow[b]{2}{*}{$\begin{array}{l}\text { Source of } \\
\text { data }\end{array}$} & \multirow[b]{2}{*}{$\begin{array}{c}\text { Physical } \\
\text { properties }\end{array}$} & \multicolumn{9}{|c|}{ Constituent group } & \multirow[b]{2}{*}{ Tota } \\
\hline & & $\begin{array}{l}\text { Inorganic } \\
\text { constituents }\end{array}$ & $\begin{array}{l}\text { Trace } \\
\text { elements }\end{array}$ & $\begin{array}{l}\text { Major } \\
\text { metals }\end{array}$ & Nutrients & $\begin{array}{c}\text { Organic } \\
\text { substances }\end{array}$ & $\begin{array}{l}\text { Priority } \\
\text { pollutants }\end{array}$ & Pesticides & $\begin{array}{l}\text { Radio- } \\
\text { chemicals }\end{array}$ & Biota & \\
\hline \multicolumn{12}{|l|}{ Federal: } \\
\hline $\begin{array}{l}\text { U.S. Geological } \\
\text { Survey. }\end{array}$ & 2 & 5 & 11 & 1 & 4 & 6 & 15 & 0 & 1 & 0 & 45 \\
\hline $\begin{array}{l}\text { Other Department } \\
\text { of the Interior } \\
\text { agencies. }\end{array}$ & 0 & 0 & 0 & 0 & 0 & 0 & 0 & 0 & 0 & 0 & 0 \\
\hline $\begin{array}{l}\text { U.S. Environmental } \\
\text { Protection Agency. }\end{array}$ & y. & 0 & 0 & 0 & 0 & 0 & 0 & 0 & 0 & 0 & 0 \\
\hline Other Federal & 0 & 0 & 0 & 0 & 0 & 0 & 0 & 0 & 0 & 0 & 0 \\
\hline $\begin{array}{l}\text { Total, Federal } \\
\text { agencies. }\end{array}$ & 2 & 5 & 11 & 1 & 4 & 6 & 15 & 0 & 1 & 0 & 45 \\
\hline
\end{tabular}

State:

\begin{tabular}{|c|c|c|c|c|c|c|c|c|c|c|c|}
\hline $\begin{array}{l}\text { Ohio Environmental } \\
\text { Protection Agency. }\end{array}$ & 0 & 0 & 0 & 0 & 0 & 0 & 0 & 0 & 0 & 0 & 0 \\
\hline Other State & 0 & 0 & 0 & 0 & 0 & 0 & 0 & 0 & 0 & 0 & 0 \\
\hline $\begin{array}{l}\text { Total, State } \\
\text { agencies. }\end{array}$ & 0 & 0 & 0 & 0 & 0 & 0 & 0 & 0 & 0 & 0 & 0 \\
\hline $\begin{array}{l}\text { Regional: Inter- } \\
\text { state agencies. }\end{array}$ & 0 & 0 & 0 & 0 & 0 & 0 & 0 & 0 & 0 & 0 & 0 \\
\hline Local agencies. & 0 & 0 & 0 & 0 & 0 & 0 & 0 & 0 & 0 & 0 & 0 \\
\hline $\begin{array}{l}\text { Academic } \\
\text { institutions. }\end{array}$ & 0 & 0 & 0 & 0 & 0 & 0 & 0 & 0 & 0 & 0 & 0 \\
\hline $\begin{array}{l}\text { Total (rounded) } \\
\text { all organizations. }\end{array}$ & 2 & 5 & 11 & 1 & 4 & 6 & 15 & 0 & 1 & 0 & 45 \\
\hline
\end{tabular}

